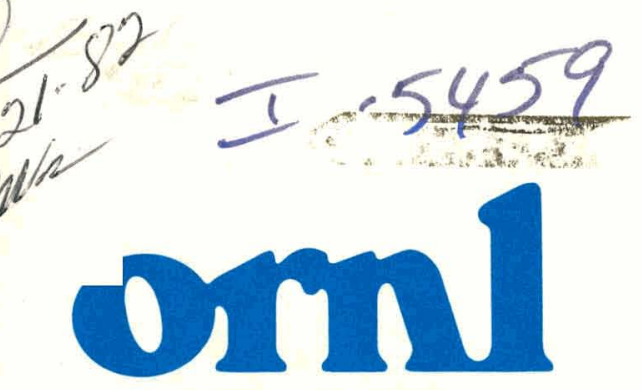

OAK

RIDGE

NATIONAL

LABORATORY

UNION

CARBIDE

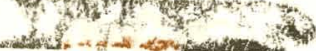

ORNL/TM-8160

MASTER

Preliminary Flashing Multiphase Flow Analysis with Application to Letdown Valves in Coal Conversion Processes
L. J. Ott
A. A. Khan

ORNL/TM--8160

DE82 021090
OPERATED BY

UNION CARBIDE CORPORATION FOR THE UNITED STATES DEPARTMENT OF ENERGY

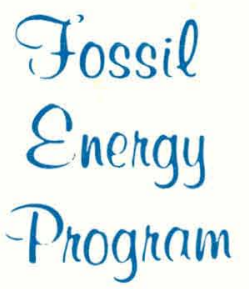




\section{DISCLAIMER}

This report was prepared as an account of work sponsored by an agency of the United States Government. Neither the United States Government nor any agency Thereof, nor any of their employees, makes any warranty, express or implied, or assumes any legal liability or responsibility for the accuracy, completeness, or usefulness of any information, apparatus, product, or process disclosed, or represents that its use would not infringe privately owned rights. Reference herein to any specific commercial product, process, or service by trade name, trademark, manufacturer, or otherwise does not necessarily constitute or imply its endorsement, recommendation, or favoring by the United States Government or any agency thereof. The views and opinions of authors expressed herein do not necessarily state or reflect those of the United States Government or any agency thereof. 


\section{DISCLAIMER}

Portions of this document may be illegible in electronic image products. Images are produced from the best available original document. 
Printed in the United States of Amerira Availahle from National Technical Information Service

U.S. Department of Commerce

5285 Port Royal Road, Springfield, Virginia 22161

NTIS price codes-Printed Copy: A07; Microfiche A01

This report was prepared as an account of work sponsored by an agency of the United States Government. Neither the United States Government nor any agency thereof, nor any of their employees, makes any warranty, express or implied, or assumes any legal liability or responsibility for the accuracy, completeness, or usefulness of any information, apparatus, product, or process disclosed, or represents that its use would not infringe privately owned rights. Reference herein to any specific commercial product, process, or service by trade name, trademark, manufacturer, or otherwise, does not necessarily constitute or imply its endorsement, recommendation, or favoring by the United States Government or any agency thereof. The views and opinions of authors expressed herein do not necessarily state or reflect those of the United States Government or any agency thereof. 


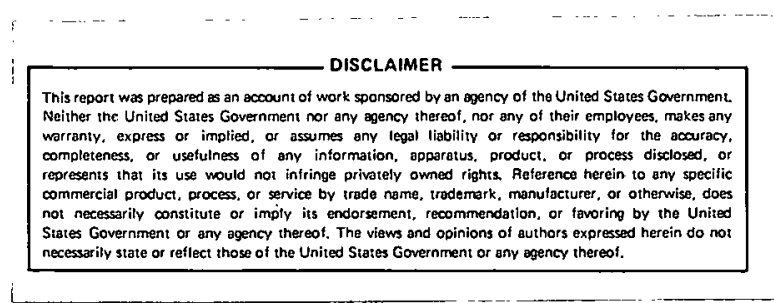

ORNL/TM-8160

Contract No. W-7405-eng-26

Engineering Technology Division

\section{PRELIMINARY FLASHING MULTIPHASE FLOW ANALYSIS WITH APPLICATION TO LETDOWN VALVES IN COAL- CONVERSION PROCESSES}

L. J. Ott A. A. Khan

Date Published - September 1982

NOTICE: This document contains information of a preliminary nature. It is subject to revision or correction and therefore does not represent a final report.

Prepared by the

OAK RIDGE NATIONAL LABORATORY

Oak Ridge, Tennessee 37830

operated by

UNION CARBIDE CORPORATION

for the

DEPARTMENT OF ENERGY 
THIS PAGE

\section{WAS INTENTIONALLY LEFT BLANK}


CONTENTS

Page

LIST OF FIGURES $\ldots \ldots \ldots \ldots \ldots \ldots \ldots \ldots \ldots \ldots \ldots \ldots \ldots \ldots \ldots \ldots \ldots \ldots \ldots \ldots \ldots \ldots$ v

LIST OF TABLES $\ldots \ldots \ldots \ldots \ldots \ldots \ldots \ldots \ldots \ldots \ldots \ldots \ldots \ldots \ldots \ldots \ldots \ldots \ldots \ldots \ldots \ldots \ldots$

SUMMARY

ABSTRACT $\quad \ldots \ldots \ldots \ldots \ldots \ldots \ldots \ldots \ldots \ldots \ldots \ldots \ldots \ldots \ldots \ldots \ldots \ldots \ldots \ldots \ldots \ldots \ldots \ldots \ldots \ldots . \ldots \ldots$

1. INTRODUCTION $\ldots \ldots \ldots \ldots \ldots \ldots \ldots \ldots \ldots \ldots \ldots \ldots \ldots \ldots \ldots \ldots \ldots \ldots \ldots \ldots \ldots$

1.1 Background $\ldots \ldots \ldots \ldots \ldots \ldots \ldots \ldots \ldots \ldots \ldots \ldots \ldots \ldots \ldots \ldots \ldots \ldots \ldots$

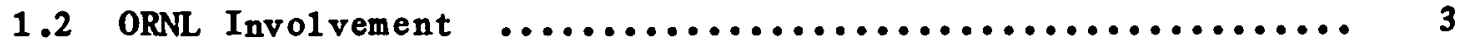

2. OBJECTIVES $\ldots \ldots \ldots \ldots \ldots \ldots \ldots \ldots \ldots \ldots \ldots \ldots \ldots \ldots \ldots \ldots \ldots \ldots \ldots \ldots \ldots \ldots . \ldots . \ldots$

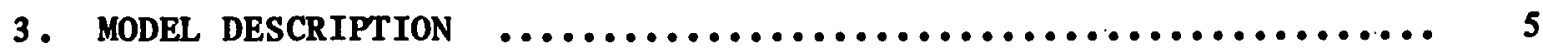

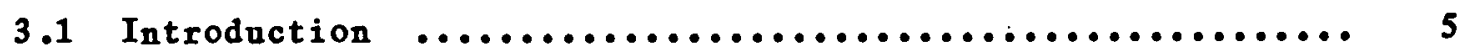

3.2 Control Vol nme Concept $\ldots \ldots \ldots \ldots \ldots \ldots \ldots \ldots \ldots \ldots \ldots \ldots \ldots \ldots$

3.3 Model Limitations ............................ 7

3.4 Physica1 Property and Thermodynamic Relationships ....... 7

3.4.1 Gas equation of state $\ldots \ldots \ldots \ldots \ldots \ldots \ldots \ldots \ldots \ldots \ldots . . \ldots$

3.4.2 Vaporization equilibrium ratios ............... 10

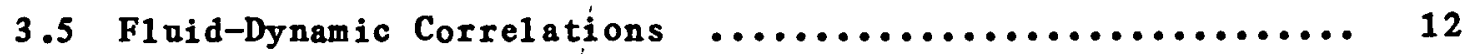

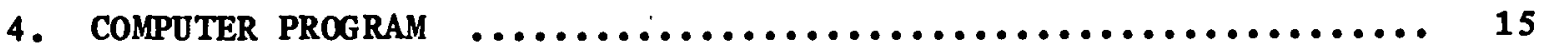

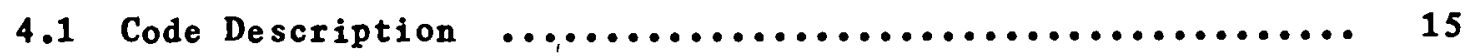

4.2 Code User Inpat Description ....................... 20

4.3 Code Output Description ......................... 26

4.4 Code Applications $. \ldots \ldots \ldots \ldots \ldots \ldots \ldots \ldots \ldots \ldots \ldots \ldots \ldots \ldots \ldots . \ldots . \ldots \ldots$

4.5 Code Verification $\ldots \ldots \ldots \ldots \ldots \ldots \ldots \ldots \ldots \ldots \ldots \ldots \ldots \ldots \ldots$

5. FUTURE MODEL IMPROVEMENTS $\ldots \ldots \ldots \ldots \ldots \ldots \ldots \ldots \ldots \ldots \ldots \ldots \ldots \ldots \ldots . \ldots$

6. CONCLUSIONS AND RECOMMENDATIONS $\ldots \ldots \ldots \ldots \ldots \ldots \ldots \ldots \ldots \ldots \ldots \ldots \ldots$

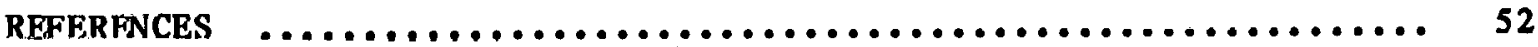

APPENDIX A. DETALED CODE INPUT DESCRIPTION $\ldots \ldots \ldots \ldots \ldots \ldots \ldots \ldots \ldots .57$

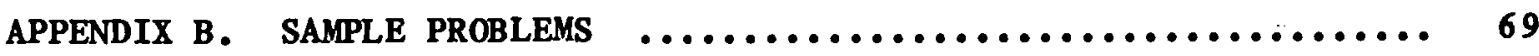

B.1 Problem Definition and Description ................. 69

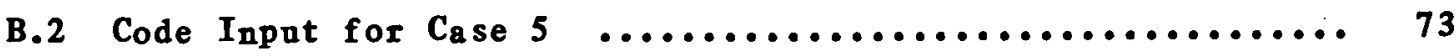

B.3 Case 1: One-Phase (Liquid) Multicomponent F1 ow ......... 75 
Page

B.4 Case 2: One-Phase (Vapor) Multicomponent F1 ow ......... 79

B.5 Case 3: Tro-Phase (Vapor/Liquid) Multicomponent F1 ow .... 83

B.6 Case 4: F1ashing Multicomponent F1ow ............... 87

B.7 Case 5: F1ashing Multicomponent F1ow with an Injected

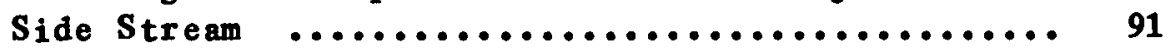




\section{LIST OF FIGURES}

Number

Page

1

3

4

5

6

7

8

9

10

11

12

13

14

15

16

17

18

A. 1

B. 1

B.2

FFFAP control volume $\ldots \ldots \ldots \ldots \ldots \ldots \ldots \ldots \ldots \ldots \ldots \ldots \ldots \ldots . \ldots 6$

Out1ine of FFFAP user input requirements $\ldots \ldots \ldots \ldots . . . . .20$

Required user input for each control volume .......... 23

Examp1e of FFFAP page 1 output .................. 28

"Starburst" ontput page ........................ 29

Control parameter 1 ibrary output ................. 30

Chemical component 1 ibrary output $\ldots \ldots \ldots \ldots \ldots \ldots \ldots \ldots \ldots . \ldots 31$

Pipe wall component 1 ibrary and experimental data sets output pages ............................. 32

Control volune 1ibrary output ................... 33

User-specified feed streams ...................... 34

Initial state of the feed stream .................. 35

Final state of the feed stream ................... 36

Examp1e of noda1 ana1ysis (f1uid, single-phase) ....... 38

Example of noda1 ana1ysis (f1 nid, two-phase) ......... 39

Piping system for sample problems ................. 42

Control volume representation of piping system for

sample problems ................................ 43

Fanning friction factor as a fuction of Reynolds number and relative roughness .................... 45

Pressure-drop correlations for slurry flow in horizonta1 pipes ............................... 46

Out1ine of FFFAP user input requirements ........... 57

Piping system for sample problems .................. 69

Control volume representation of piping system for sample prob1ems 
THIS PAGE

WAS INTENTIONALLY

LEFT BLANK 


\section{LIST OF TABLES}

Number

$\underline{\text { Page }}$

1 Summary of physical and thermodynamic property relationships employed in Version 1.0 of FFFAP

Summary of fluid-dynamic correlations employed in Version 1.0 of FFFAP

FFFAP modules (Version 1.0)

User-specified control parameter 1 ibrary

(FFFAP-Version 1.0)

5

Outline of FFFAP-Version 1.0 output

Sample problem descriptions from piping system (Fig. 15)

Comparison of pressure-drop calculations for sample prob1 em 1

Comparison of pressure-drop calculations for sample problem 2

Comparison of pressure-drop calculations for sample prob1em 3

A.1

FFFAP input blocks and card identifiers

B.1 Sample problem descriptions from piping system (Fig. B.1) 
THIS PAGE

\section{WAS INTENTIONALLY LEFT BLANK}




\section{SUMMARY}

A11 coal conversion processes require valves for controlling the flow of fluids containing solid particles and other harsh contaminants derived from coal at high temperature and/or pressure. Pilot-plant experience with coal liquefaction processes has shown that the high-pressure slurry letdown valves are prone to fail. No scientific procedure exists for accurately sizing letdown valves accepting high-pressure/high-temperature streams comprised of coal particles suspended in a mixture of hydrocarbons that undergo changes of state and composition as the fluid passes through the valve.

As part of the Oak Ridge National Laboratory's technical support to large coal liquefaction projects, attempts have been made to (1) develop the methodology for characterizing and predicting multicomponent, multiphase, non-Newtonian flow behavior within letdown valves and devices and (2) analyze the fluid flow in the entire letdown region of the process. An engineering model that can be used in the analysis of multicomponent, multiphase, flashing, flowing systems has been developed. A preliminary version of a user-oriented computer code for this model has been developed and is fully described.

Sample problems solved with the computer code ranging from singlephase multicomponent flow to flashing, multicomponent flow with an injected side stream are also presented. 


\title{
PRELIMINARY FLASHING MULTIPHASE FLOW ANALYSIS WITH APPLICATION TO LETDOWN VALVES IN COAL CONVERSION PROCESSES
}

\author{
L. J. Ott A. A. Khan
}

\begin{abstract}
As part of the Oak Ridge National Laboratory's technical support to large coal 1 iquefaction projects, attempts have been made to (1) develop the methodology for characterizing and predicting multicomponent, maltiphase, non-Newtonian flow behavior within letdown valves and devices and (2) analyze the fluid flow in the entire 1 etdown region of the process.

An engineering model that can be used in the analysis of multicomponent, multiphase, flashing, flowing systems has been developed. A preliminary version of a user-oriented computer code for this model has been developed and is fully described.
\end{abstract}

\section{INTRODUCTION}

\subsection{Background}

During the decade from 1970 to 1980 , coa 1 increased in importance as an energy source that would allow the United States to reduce its dependence on oil imports. Serious attention has been given to commercializing advanced processes for converting coal to clean liquids and gases. Most of these processes are either in the pilot-plant stage or are ready for soalo-up to demonstialiun-size units. All of these coal conversion processes require valves for controlling the flow of fluids containing solid. particles and other harsh contaminants derived from coal at high temperature and/or pressure.

An extensive studyl by J. F. Gardner of the Morgantown Energy Technology Center of the applications of valves for solids throttling in the coal conversion processes indicates two critical needs:

1. a control valve for slurry letdown service and

2. a control valve for hot dirty gas service.

Current experience with letdown valves comes from usage by existing pilot 
plants (for instance, the SRC-I facility at Wilsonville, Alabama, and the SRC-II facility at Ft. Lewis, Washington) and demonstration plants (the H-Coal facility at Catlettsburg, Kentucky). Normally, the pilot plant is used to prove or improve a chemical process; from that viewpoint, techniques are devised by the operators to keep the plant functioning long enough to collect process data in spite of equipment limitations. Such has been the case with pilot-plant slurry letdown valves. The short 1 ifetime of the valve bodies and trim has been a major concern of pilot-plant personne1, and the techniques that keep the pilot plant operating are not practical for large-scalc demonstration and/or commercial plants.

A summary of the letdown valve iequirements; tho conditions that mnst be specified to select (design) letdown valves acceptable for coal conversion, and the industry's current ability to supply these valves has been published by Hatcher et $a .^{2}$ at the Oak Ridge National Laboratory (ORNL). Hatcher states that these letdown valves are exposed to very erosive and corrosive streams containing solids at high temperatures and pressures. Under these conditions, the valve body design, valve trim material characteristics, stream conditions (proneness to f1ashing and/or cavitation), and piping geometry upstream and downstream of the valve are important.

However, no scientific procedure presently ${ }^{3}$ exists for accurately calculating the size of letdown valves accepting slreams comprised of ooal particles suspended in a mixture of hydrocarbons that undergo changes of state (flashing) and composition as the fluid passes through the valve. There is a tendency to oversize these valves, which can result in rapid erosion of the trim among other effects. Somedesign engineers of the valve manufacturers will admit that for this application their design methods range from "educated guesswork" to "seat of the pants engineering."

Considering the magnitude of the problems encontcrud will 1etdown valves in coal conversion pilot plants, several needs must be met before these equipment items can become reliable, integrated units in future coal conversion demonstraliou and commcroial plante. First, as stated by Hatcher ${ }^{2}$ and Bhide, 3 the data required for proper valve design must be accumulated. The best place to acquire these data is in existing operating pilot and demonstration plants. Second, efforts should be made to 
learn from past pilot-plant operating experience: that is, a survey of pilot-plant engineers and operators should be made to determine (1) what valves were used for this service, (2) whether or not they failed, (3) how long they operated, (4) the failure mode, (5) the condition of the valve after removal, (6) the measures taken to fix the valve and put it back in service, and especially (7) any "break-through" that allowed reasonably reliable valve operation. A common complaint of valve manufacturers is the lack of feedback from past pilot-plant experience. Finally, a "design tool" should be developed that would allow the engineer to analyze the flow of coal liquids mixed with solids and gases undergoing flashing at adiabatic and nonadiabatic conditions. This design tool would provide the nonexistent scientific procedure referred to by Bhide.

\subsection{ORNL Involvement}

In the area of component development and process evaluation, the ORNL objective is to ensure that coal conversion (1iquefaction, gasification, pyrolysis) processes, subsystems, and components have satisfactory functional performance, 1 ifetime, reliability, and safety for their intended applications, and that sufficient component and subsystem performance data are available to permit process design optimizations. Current activities are primarily those carried out as part of the technical support to large 1 iquefaction projects.

The objectives of the ORNL letdown valve reliability subtask are (1) to collect information and data on past slurry letdown valve performance, (2) to develop the methodology for characterizing and predicting mul ticomponent, multiphase, non-Newtonian flow behavior within 1 etdown valves and devices, and (3) to analyze the fluid flow in the entire letdown region of the process. Ultimately, this subtask goal is to provide recommendations, guidelines, and engineering techniques for the design and modification of sluxry letdown valves and systems.

Data and information on pilot-plant letdown valve experience (primarily SRC-I and SRC-II) and related industrial experience have recently been collected and published.4 Items 2 and 3 of the letdown valve reliability subtask are addressed by this report. 


\section{OBJECTIVES}

The primary objective of this study is the development of an engineering model that can be used in the analysis of multicomponent, multiphase, flashing, flowing systems. This preliminary engineering tool is presented as a computer program, Version 1.0 of the Flashing F1uid Flow Analysis Program (FFFAP).

This engineering model was developed with intended application to coal 1iquefaction high-pressure letdown systems. Specific applications (after verification) include the following:

1. evaluation of existing (and past) high-pressure letdown systems (valves and piping),

2. evaluation of proposed letdown systems, and

3. design of new letdown systems.

Final verification and application of the code to existing (and past) pilot-plant and demonstration plant high-pressure letdown systems will be reported in a subsequent publication.

Note that the FFFAP engineering model and code is highly generalized. Although designed for the analysis of the coal liquefaction letdown system, it can be applied to any piping systam with any fluid constilueuls. 


\section{MODEL DESCRIPTION}

\subsection{Introduction}

The engineering therma1-hydraulic mode1 of the fluid system essentially consists of macroscopic mass, momentum, and energy balances on incremental segments of the system. Thus, by specifying the initial boundary conditions and with a steady-state limitation, the equations of change can be step-wise integrated along the entire length of the flow system. Therefore, the results (temperature, pressure, etc.) from the model are computed as functions of position in the flow system.

Note that these are preliminary versions of the model and the code. Because of time constraints, some features (such as the nonadiabatic and non-Newtonian capabilities) have not been verified and included in the first release of the code. In the remaining sections of Chap. 3 , attention is drawn to those features that will be added at a later date; a more in-depth coverage of future model improvements is presented in Chap. 5 .

\subsection{Control Volume Concept}

The fluid system to be analyzed by FFFAP must be fully specified by the user. The user describes the system geometry by specifying fluid volumes and junctions (flow paths) between the volumes. These nser-specified volumes (control volumes) are the "incremental segments" around which the equations of change are formulated and are used to represent the filuid in the system piping.

Consider the control volume shown in Fig. 1; because this is a steadystate initial value problem, the inputs to the control volume are known. Then via the mass, momentum; and energy balances, the control volume ontputs can be calculated.

Thus, FFFAP considers a therma1-hydraulic system as a series of interconnected user-defined control volumes. The FFFAP code then solves the equations of change for the volumes under the 1 imitations given in Sect. 3.3. 
ORNL-DWG 82-5235 ETD

INCREMENTAL LENGTH

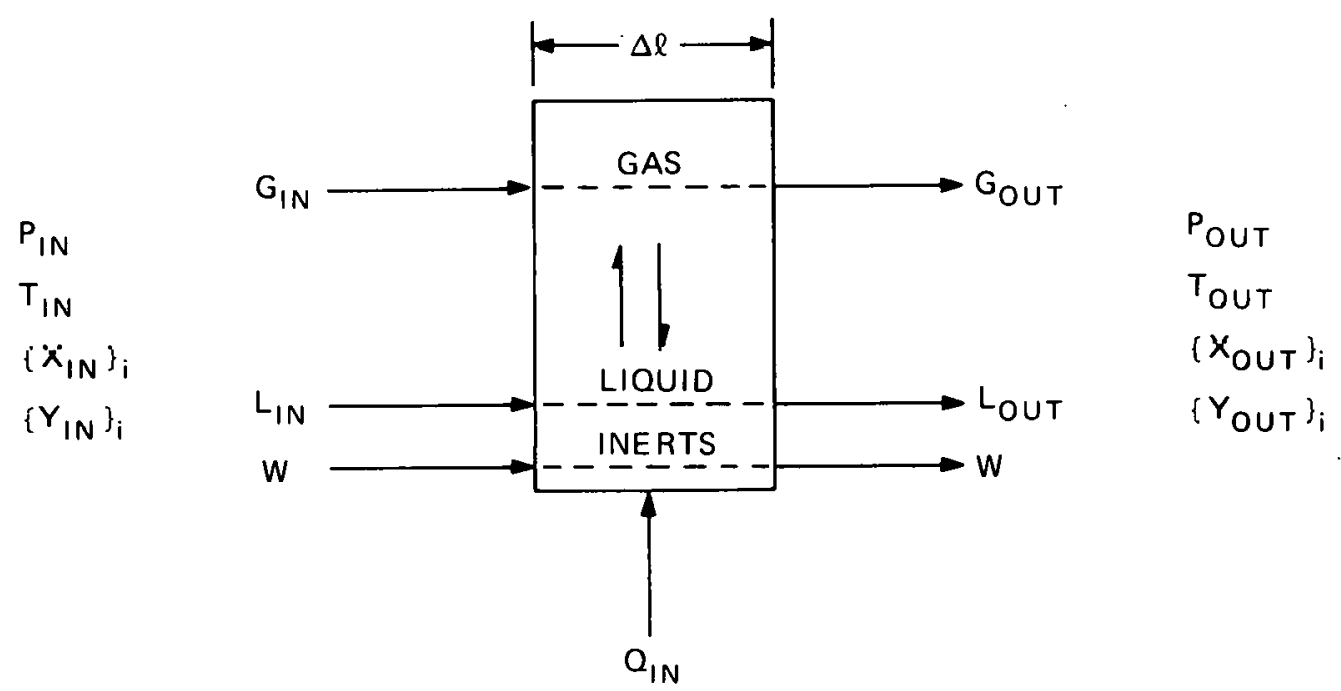

KNOWNS:

$P_{\text {IN }}$

TIN

$\left\{X_{I N}\right\}_{i},\left\{Y_{I N}\right\}_{i}$

$G_{I N}, L_{I N}, W$

$\mathrm{Q}_{1 \mathrm{~N}}$

UNKNOWNS:

POUT

TOUT

$\left\{X_{\text {OUT }}\right\}_{i},\left\{Y_{\text {OUT }}\right\}_{i}$

$G_{\text {OUT }}, L_{\text {OUT }}, W$
PRESSURE IN

TFMPF RATIIRF IN

CONSTITUENT CONCENTRATION OF THE INLET LIQUID AND GAS STREAMS. RESPECTIVELY

FLOW RATES OF INLET GAS, LIQUID AND INERT ETREAME

HEAT INPUT OVER THE INCREMENTAL LENGTH $\triangle R$

PRESSURE OUT

TEMPERATURE OUT

CONSTITUENT CONCENTRATION OF THE OUTLET STREAMS

OUTLET FLOW RATE'S OF THE GAS, LIUUID AND INERT STREAMS

Fig. 1. FFFAP control volume. 


\subsection{Mode1 Limitations}

The engineering mode 1 and FFFAP-Version 1.0 have the following 1 imitations and assumptions:

1. the flow is one-dimensional and steady-state;

2. the gas and liquid streams are in thermodynamic equilibrium;

3. the fluid is homogeneous (i.e.. no slip):

4. available fluid-dynamic and thermodynamic correlations are used;

5. the process is adiabatic (Version 1.0 only);

6. the fluid is Newtonian. (Version 1.0 on1y);

7. the user cannot specify experimentally available liquid density, viscosity, and 1 iquid/gas interfacial surface tension (Version 1.0 only); and

8. no chemical reaction occurs.

\subsection{Physical Property and Thermodynamic Relationships}

Reliable values of the properties of materials are essential in the design, operation, and analysis of industrial equipment and processes. Reliable experimental data are always to be preferred over values obtained by even the best estimation methods; however, if the process involves chemical mixtures or relatively new materials, available experimental data may not exist. For instance, the coal liquids from 1 iquefaction processes are complex mixtures of individual chemical compounds, the formation of which are dependent on the process, the operating conditions, and the coal type used; however to date, the physical and thermodynamic properties of these liquids are still being researched. Nevertheless, the lack of data does not alleviate the engineer's need for the data, and in such cases, the data must be estimated.

The work relies heavily on the critical review of Reid. Prausnitz, and Sherwoods of various estimation procedures for a 1 imited number of properties of gases and 1 iquids and the more timely comments of Henley and Seader. Also, a literature survey has been made of recent research in physical property and thermodynamic property estimation procedures. An effort has been made to include in the engineering model and FFFAP the 
best methods of estimating each property. (In some cases, there are several methods: thus, the code user has a choice of techniques).

Version 1.0 of FFFAP does not have the capability of allowing the user to input experimental1y available mixture liquid density, viscosity, liquid/gas interfacial surface tension, or equilibrium vapor/liquid ratios (K values). This improvement will be made in the next version of FFFAP.

A summary ${ }^{7-18}$ of the physical property and thermodynamic relationships employed in Version 1.0 of FFFAP is given in Table 1 . Inc1uded in parentheses in Table 1 are correlations that are intended to be added in a subsequent versinn nf FFFAP,

\subsubsection{Gas equation of state}

In high-pressure gas/1iquid systems, there is a need to estimate the volumetric behavior of a real gas, becanse significant departures from tho low-pressure ideal gas assumptions can exist. The nonideality of a gas is conveniently expressed by the compressibility factor $Z$ as

$$
\mathbf{Z}=\frac{\mathbf{P V}}{\mathbf{R T}}
$$

where

$$
\begin{aligned}
& V=\text { molar volume, } \\
& P=\text { absolnte pressire, } \\
& T=\text { absolute temperature, and } \\
& R=\text { universal gas constant. }
\end{aligned}
$$

For ideal gases $L=1.0$; for real gases, $Z$ is norma11y less than unity, except at very high pressures or temperatures.

The analytical modified Redich-Kwong-Soave equation of state is used in FFFAP. For hydrocarbon systems, Reid et al. suggested the Redlich-Kwong-Soave and Lee-Erbar-Edmister equations of state and noted that they were generalized equations, accurate to within 1 to $2 \%$, and wel1 tested. However, the one exception to their recommendation was systems containing hydrogen. Recent work by Graboski and Dauberti-16 has resulted in the modified Redlich-Kwong-Soave equation of state that does not have the previous restriction. The atility of the equation has been 
Table 1. Summary of physical and thermodynamic property relationships employed in Version 1.0 of FFFAP

\begin{tabular}{|c|c|c|}
\hline $\begin{array}{l}\text { Physical or } \\
\text { thermodynamic } \\
\text { property }\end{array}$ & Correlation ${ }^{a}$ & References \\
\hline $\begin{array}{l}\text { Enthalpy: including subcooled } \\
\text { liquid, saturated liquid, } \\
\text { saturated vapor, and } \\
\text { superheated vapor }\end{array}$ & $\begin{array}{l}\text { Yen and Alexander } \\
\text { (Lee, Erbar, and } \\
\text { Edmister) } \\
\text { (Edmister, Persyn, } \\
\text { and Erbar) }\end{array}$ & $\begin{array}{l}5,7 \\
5,8 \\
6\end{array}$ \\
\hline Liquid density & $\begin{array}{l}\text { Chueh/Prausnitz } \\
\text { (Yeh and Woods) } \\
\text { (User-supplied) }\end{array}$ & $\begin{array}{l}5,9,10 \\
5,11\end{array}$ \\
\hline Liquid activity coefficient & $\begin{array}{l}\text { Scatchard/Hildebrand } \\
\text { (Scatchard/Hildebrand } \\
\text { with Lee, Erbar, and } \\
\text { fdmister interaction } \\
\text { coefficients) }\end{array}$ & 5,12 \\
\hline Liquid fugacity coefficient & $\begin{array}{l}\text { Grayson/Streed } \\
\text { (Lee, Erbar, and } \\
\text { Edmister) }\end{array}$ & $\begin{array}{l}13 \\
8\end{array}$ \\
\hline Vapor fugacity coefficient & $\begin{array}{l}\text { Modified Redlich-Krong- } \\
\text { Soave equation of state } \\
\text { (Lee, Erbar and Ed- } \\
\text { mister equation of } \\
\text { state) }\end{array}$ & $\begin{array}{l}14,15,16 \\
5,8\end{array}$ \\
\hline $\begin{array}{l}\text { Liquid/vapor interfacial } \\
\text { surface tension }\end{array}$ & $\begin{array}{l}\text { Mac1 eod/Sugden } \\
\text { (User-supp1 ied) }\end{array}$ & 5 \\
\hline Liquid viscosity $b$ & $\begin{array}{l}T_{T} \leq 0.75 \text { vanVelzen } \\
T_{r}>0.75 \text { Letsou/Stiel } \\
\mu_{m}=e\left(\Sigma_{\chi_{i}} \ln \mu_{i}\right) \\
\text { (User-supplied) }\end{array}$ & $\begin{array}{l}5 \\
5,17 \\
5\end{array}$ \\
\hline Vapor viscosity & Dean and Stiel & 5,18 \\
\hline
\end{tabular}


we11 demonstrated,14-16 especially for vapor-1iquid equilibria calculations for mixtures of hydrocarbons of importance to the natural gas and petroleum refining industries.

The equation of state can also be used to compute the vapor-mixture enthalpy:3,6 combined with the 1 iquid mixtare enthalpy computation technique of Edmister et a1..' the enthalpy of any state point can be calcu1ated.

The fugacity coefficient of a component in the vapor phase is needed to predict phase equilibrium. The vapor-phase fugacity coefficient can also be determined via the equation of state (classical derivation).

\subsubsection{Vaporization equilibrium ratios}

A general correlation of vapor/liquid equilibria for a large class of mixtures is much needed in engineering calculations where generality, reliability, and ease of use are primary considerations. In the FFFAP model, every iteration in the solution of the equations of change for a control volume requires multiple evaluations of vaporization equilibrium ratios ( $K$ values) just in the determination of the mixture bubble-point and dew-point temperatures. Also, if the fluid is two-phase (bubble-point temperature ( fluid temperature ( dew-point temperature), additional R-value computations must be made to determine the vapor/liquid split.

Vaporization equilibrium ratios are calculated in the model according to the thermodynamic identity

$$
\mathbf{K}_{i}=\frac{\nu_{i} \gamma_{i}}{\phi_{i}},
$$

where the subscript refers to component identity. $K_{i}$ is defined as the ratio of the mole fractions in the equilibrium gas and liquid phases,

$$
\mathbf{K}_{\mathbf{i}}=\mathbf{Y}_{\mathbf{i}} / \mathbf{X}_{\mathbf{i}}
$$

where $Y_{i}$ and $X_{i}$ are the vapor and liquid mole fractions, respectively, of component $i$. 
The other quantities in Eq. (2) are

$v_{i}=$ fugacity coefficient of component $i$ as a pure 1 iquid,

$\gamma_{i}=$ activity coefficient of $i$ in the liquid solution, and

$\phi_{i}=$ fugacity coefficient of $i$ in the vapor mixture.

As noted in Sect. 3.4.1, the fugacity coefficient $\phi_{i}$ of $i$ in the vapor mixture can be determined via a classical thermodynamic derivation using the equation of state. The derivation starts with the relation of the chemical potential to the Gibbs or Helmholtzenergies. The details will not be given here; rather, the reader is referred to thermodynamic texts, Reid et a1.3 or Henley and Seader. The point to be made is that, given an equation of state for the gas, an expression for the fugacity coefficient $\phi_{i}$ can be defined from thermodynamic relationships.

The fugacity coefficient $\left(\nu_{i}\right)$ of $i$ as a pare liquid is determined from the Grayson/Streed correlation, 13 which is an extension of the Chao/ Seaderig empirical expression for $\nu_{i}$ in terms of the reduced temperature $T_{r}$, reduced pressure $P_{r}$, and the acentric factor $\omega$.

The 1 iquid activity coefficient $\gamma_{i}$ of $i$ is calculated by the Scatchard/Hildebrand12 (solubility-parameter) equation, assuming "regular" liquid solutions. A regular solution is one in which nonideality is caused entirely by the heat of mixing. The properties of solutions of nonpolar fluids such as hydrocarbons are approximated by regular solution equations. The Scatchard/Hildebrand relation gives the activity coefficient as a function of temperature and composition, but it is independent of pressure.

As noted earlier, reliable experimental data are preferable, and this would be especia11y true for the K-value determination. A future version of FFFAP should include the capability (option) of allowing the user to input a $\mathrm{K}$-value subroutine in which experimental values of $\mathrm{K}$ are determined as functions of pressure and temperature. However, this option is not available in Version 1.0; thus, the vaporization equilibria ratios are computed via Eq. (2). 


\subsection{Flnid-Dynamic Correlations}

For single-phase (gas or liquid) Newtonian flow our engineering foundation is very firm; 1 ittle improvement has been made in our knowledge of the effect of Reynolds number Re and relative pipe roughness $k / d$ on the turbulent friction factor $f$ since 1940 . The one possible exception is Wood's2o (1966) empirical set of equations that are explicit in $f$. The turbulent-flow friction factor relations (Wood2o and Colebrooke correlations for partially rough wall turbulence; Nikuradsezo correlation for fully rough wall turbulence; Drew et a1.20 and Nikuradse 20 correlations for smooth wall turbulence) combined with the laminar relationship ( $f=$ $16 / R e)$ and a smooth transition between laminar and turbulent flow are commonly known in a graphical form as a Moody'i diagram. These relations are al1 combined in one routine in FFFAP that, given an Re and k/d set, calculates the friction factor $f$.

Version 1.0 of FFFAP has been 1 imited to Newtonian fluids. NonNewtonian flow and the option that would allow the user to include his own 1 iquid viscosity relationship will be included in a later version of FFFAP.

The subject of two-phase flow in pipes is not as straightforward as that of single-phase Newtonian flow. Since Lockhart and Martine11i2a published their two-phase correlation in 1949, dozens of correlations and models have been published for dealing with various aspects of the flow of gas-1iquid mixtures in pipes. Thankfully, some researchers, the most prominent being Dukler et al, at the University of Houston and Gregory et a1. at the University of Calgary, have undertaken critical reviews of existing correlations, thus easing the task of the engineer who must select one of these methods for use in a particular problem. These reviews s-31 $^{2}$ have definitely had a bearing on the correlations chosen for inclusion in Version 1.0 of FFFAP. The correlations currently in FFFAP for the twophase flow friction factor, the liquid holdup, and the flow pattern maps for vertical and horizontal flow are presented in Tahle 2.

Two-phase flow of solids and gas or solids and liquid is discussed extensively by Govier and Aziz.20 Relying on their critique and including the 1atter work of Turian and Yuan, ${ }^{32}$ five correlations are available in 
Table 2. Summary of f1nid-dynamic correlations employed in Version 1.0 of FFFAP

\begin{tabular}{|c|c|c|}
\hline App1 ication & Correlation ${ }^{a}$ & References \\
\hline \multicolumn{3}{|l|}{ Single-phase friction factor } \\
\hline $\begin{array}{l}\text { Partially rough wall turbu- } \\
\text { lence } \\
\text { Fully rough wall turbulence } \\
\text { Smooth wall turbulence. }\end{array}$ & $\begin{array}{l}\text { Wood } \\
\text { Colebrook } \\
\text { Nikuradse } \\
\text { Drew, Koo, and McAdams } \\
\text { Nikuradse }\end{array}$ & $\begin{array}{l}20 \\
20 \\
20 \\
20 \\
20\end{array}$ \\
\hline \multicolumn{3}{|l|}{$\begin{array}{l}\text { Two-phase (solid and gas or } \\
\text { liquid) friction factor }\end{array}$} \\
\hline Vertical f1 ow & $\begin{array}{l}\text { Newitt, Richardson, and } \\
\text { G1iddon }\end{array}$ & 33 \\
\hline 、 & $\begin{array}{l}\text { Turian/Yuan } \\
\text { Rose/Duckworth }\end{array}$ & $\begin{array}{l}32 \\
34\end{array}$ \\
\hline Horizontal flow & $\begin{array}{l}\text { Newitt et al. } \\
\text { Rose/Duckworth } \\
\text { Zandi/liovatos } \\
\text { Turian/Yuan }\end{array}$ & $\begin{array}{l}35 \\
34 \\
20 \\
32\end{array}$ \\
\hline \multicolumn{3}{|l|}{$\begin{array}{l}\text { Two-phase (gas and liquid) } \\
\text { friction factor }\end{array}$} \\
\hline Vertical fl ow & $\begin{array}{l}\text { Orkiszewski } \\
\text { (Other) }\end{array}$ & 36 \\
\hline Horizontal flow & $\begin{array}{l}\text { Dukler } \\
\text { Lockhart/Martine11i } \\
\text { (Other) }\end{array}$ & $\begin{array}{l}24,37 \\
22,24\end{array}$ \\
\hline \multicolumn{3}{|l|}{ Liquid holdup in two-phase flow } \\
\hline Vertical flow & $\begin{array}{l}\text { Hughmark } \\
\text { (Other) }\end{array}$ & 24,38 \\
\hline Horizonta 1 fl ow & $\begin{array}{l}\text { Hughmark } \\
\text { Duk1er } \\
\text { Lockhart/Martine11i }\end{array}$ & $\begin{array}{l}24,38 \\
25 \\
22,24\end{array}$ \\
\hline \multicolumn{3}{|l|}{$\begin{array}{l}\text { F1 ow pattern maps for two-phase } \\
\text { f1 ow }\end{array}$} \\
\hline Vertical flow & $\begin{array}{l}\text { Dukler } \\
\text { (Other) }\end{array}$ & 26 \\
\hline Horizontal flow & $\begin{array}{l}\text { Mandhane, Gregory, and } \\
\text { Aziz } \\
\text { (Other) }\end{array}$ & 27 \\
\hline
\end{tabular}


FFFAP for the two-phase (solid and gas or 1iquid) friction factor for vertical and horizontal flow.

A summary of the fluid-dynamic correlations employed in Version 1.0 of FFFAP is presented in Table 2 . 


\section{COMPUTER PROGRAM}

\subsection{Code Description}

Version 1.0 of FFFAP is written in FORTRAN IV and is currently operable on ORNL's IBM 3033 computer. The code consists of 36 modules (subroutines, function subprograms, etc.), each of which is designed primarily for one function. The entire code requires $410 \mathrm{~K}$ bytes of computer core storage. A summary of the FFFAP modules (a total of 36) is presented in Table 3 along with a very brief description of each module function. In any given problem, many of these routines will not be used. The code user has some control (via input control parameters which will be described 1ater) over which modules will be involved in the calculations. For instance, the user has the choice of four friction factor correlations for horizontal pipeline slurry flow; in a specific problem, only one of these correlations (the user's choice) will be used.

In reviewing the FFFAP module descriptions in Table 3 , it becomes apparent that the modules are functionally designed for one general purpose only. For example, CUBE determines the roots of a cubic equation, and FICFAC returns the Fanning friction factor for a given Reynolds number and relative roughness value. What cannot be seen from these module descriptions is the logic transfer and the basic building blocks (1ibraries) that are used for information transfer within the code. Six specific

"libraries" must be generated by the code user:

1. control volume geometry,

2. chemical component,

3. wa11 component,

4. experimenta1 data,

5. feed streams, and

6. $\log$ ic control.

A detailed description of what is required in these libraries is covered in Sect. 4.2 and Appendix A. The remaining paragraphs in this section contain overview comments on the libraries.

The fluid system to be analyzed by FFFAP must be fully spooifiod by the user. It must be modeled by fluid volumes (control volumes) that the 
Table 3. FFFAP modules (Version 1.0)

\begin{tabular}{|c|c|}
\hline $\begin{array}{c}\text { Module } \\
\text { (multiple entries) }\end{array}$ & Description \\
\hline MAIN & $\begin{array}{l}\text { The main driver or controlling routine that } \\
\text { (1) directs the proper sequence calls to the } \\
\text { supporting routines and (2) contains the pri- } \\
\text { mary pressure convergence sections and the } \\
\text { side stream injection flow section }\end{array}$ \\
\hline BLOCK & Initializes the common block variables \\
\hline $\begin{array}{l}\text { BUBPRS } \\
\text { (DEWPRS) }\end{array}$ & $\begin{array}{l}\text { Solved by FALSE to determine the bubble- and } \\
\text { dew-point pressures for a stream of n compo- } \\
\text { nents at a given composition and temperature }\end{array}$ \\
\hline $\begin{array}{l}\text { BUBTMP } \\
\text { (DEWTMP) }\end{array}$ & $\begin{array}{l}\text { Solved by FALSE to determine the bubble- and } \\
\text { dew-point temperatures for a stream of } n \text { com- } \\
\text { ponents at a given composition and pressure }\end{array}$ \\
\hline CUBE & $\begin{array}{l}\text { Solves for (1) the roots of a cubic equation } \\
\text { and (2) the compressibility factor using the } \\
\text { modified Redich-Kwong-Soave equation of } \\
\text { state } 4-16\end{array}$ \\
\hline DPCALC & $\begin{array}{l}\text { Controls the pressure-drop calculations; that } \\
\text { is, depending on the state of the fluid and } \\
\text { the user input control parameters, control is } \\
\text { switched to the proper section and correlation } \\
\text { in the routine }\end{array}$ \\
\hline DUKLER & $\begin{array}{l}\text { Determines the frictional pressurc loss for } \\
\text { gas/1iquid flow in horizontal piping using } \\
\text { Dukler et al. correlations }{ }^{23}, 3\end{array}$ \\
\hline DUKRL & $\begin{array}{l}\text { Determines the liquid holdup in cocurrent gas/ } \\
\text { liquid flow in horizontal piping using } \\
\text { Dakler's methods }\end{array}$ \\
\hline ENTHYA & $\begin{array}{l}\text { Determines the enthalpy of a specified stream } \\
\text { (giveu its state) by tho mothod of Yen and } \\
\text { Alexanders,? }\end{array}$ \\
\hline FALSE & $\begin{array}{l}\text { Given a function of } X, f(X) \text {, FALSE determines } \\
\text { the value of } X \text { for which } f(X)=0 \text { via the } \\
\text { method of Reguli Falsi (bubble-point and dew- } \\
\text { point pressures and temperatures and SUMDXY) }\end{array}$ \\
\hline FALSE2 & $\begin{array}{l}\text { Same as FALSE except it is only used in the } \\
\text { solution of HBAL }\end{array}$ \\
\hline FICFAC & $\begin{array}{l}\text { Given the Reynolds number and the relative } \\
\text { roughness factor. FICFAC determines the } \\
\text { Fanning friction factor }\end{array}$ \\
\hline FINDS & A Lagrangean interpolation routine \\
\hline
\end{tabular}


Table 3 (continued)

\begin{tabular}{|c|c|}
\hline $\begin{array}{c}\text { Module } \\
\text { (multiple entries) }\end{array}$ & Description \\
\hline FPTHOR & $\begin{array}{l}\text { Determines the flow pattern region for two- } \\
\text { phase gas/1iquid cocurrent flow in horizontal } \\
\text { pipes, according to the flow pattern map of } \\
\text { Mandhane et al.27 }\end{array}$ \\
\hline FPTVRT & $\begin{array}{l}\text { Determines the flow pattern region for two- } \\
\text { phase gas/1iquid cocurrent flow in vertical } \\
\text { pipes via the flow transition criteria of } \\
\text { Dukler et a } 1.26\end{array}$ \\
\hline GAMMAI & $\begin{array}{l}\text { Computes the activity coefficients in the } \\
\text { liquid solution by the Scatchard-Hildebrand } \\
\text { relationships,12 }\end{array}$ \\
\hline
\end{tabular}

HBAL

Solved by FALSE2 to determine the root (i.e., the temperature) of a control volume heat ba 1 ance

HUPGAH

Determines the 1 iquid holdup in cocurrent gas/1iquid f1 ow for horizontal, inclined, or vertical flow via Hughmark's correlation ${ }^{24,38}$

IFLASB

Given a stream of $n$ components with known composition and stream temperature and pressure, IFLASH determines the condition of the stream and, if two-phase, performs isothermal flash calculations to determine the vapor/liquid split

INPUT

Reads the user-generated input stream (ergo, card image deck)

KVALUE

Calculates the vaporization equilibria ratios

LIQDEN

Determines the liquid density of a mixture via the Chueh/Prausnitz correlations,9,10

LOCHRT

Determines the frictional pressure loss for gas/liquid flow in horizontal piping using the method of Lockhart and Martine11i2, 34

NEWHOR

Determines the friction factor for horizontal pipeline flow of slurries via the correlation of Newitt et al.3s

NEWVRT

Determines the friction factor for vertical pipeline flow of slurries via the correlation of Newitt et a1.33 
Table 3 (continned)

\begin{tabular}{|c|c|}
\hline $\begin{array}{c}\text { Module } \\
\text { (multiple entries) }\end{array}$ & Description \\
\hline NUGRSD & $\begin{array}{l}\text { Computes the fugacity coefficients for the } \\
\text { pure components in the liquid phase by the } \\
\text { Grayson/Streed correlation }\end{array}$ \\
\hline ORKISZ & $\begin{array}{l}\text { Follows the method developed by } J \text {. } \\
\text { Orkiszewskis for calculating the pressure } \\
\text { gradient in veiticul lwuphase flow }\end{array}$ \\
\hline $\begin{array}{l}\text { OUTPT1 } \\
\text { (OUTPT2, OUTPT3, } \\
\text { OUTPT4) }\end{array}$ & $\begin{array}{l}\text { Does all of the FFFAP-generated ontput (except } \\
\text { for error messages) }\end{array}$ \\
\hline PHIRKS & $\begin{array}{l}\text { Determines the fugactiy coefficients of the } \\
\text { gas mixture and the gas compressibility factor } \\
\text { by the modified Red1ich-Kwong-Soave equation } \\
\text { of state14-16 }\end{array}$ \\
\hline ROSDUC & $\begin{array}{l}\text { Determines a slurry friction factor for ver- } \\
\text { tical and horizontal flow of fluid/solid mix- } \\
\text { tures via the Rose and Duckworth correlation }\end{array}$ \\
\hline SUMDXY & $\begin{array}{l}\text { Solved by FALSE to determine the mole fraction } \\
\text { vaporized for a feed stream of n components at } \\
\text { a given composition, temperature and pressure }\end{array}$ \\
\hline SURTEN & $\begin{array}{l}\text { Computcs the surface teinsiou of the mixtare by } \\
\text { the Macleod/Sugden ourreluliuns }\end{array}$ \\
\hline TURYUN & $\begin{array}{l}\text { Determines the friction factor for flow of } \\
\text { slurries in horizontal pipelinos based on the } \\
\text { work of Turian and Yuan }\end{array}$ \\
\hline TURVRT & $\begin{array}{l}\text { Determines the friction factor for flow of } \\
\text { siurries 1n vertionl pipclines via the Turiaul } \\
\text { Yaan correlation }\end{array}$ \\
\hline VISLIQ & $\begin{array}{l}\text { Depending on the reduced temperature, compo- } \\
\text { nent liqnid viscosity is oomputed by the van } \\
\text { van Velzen method or Letson/Stiel correla- } \\
\text { tion; } \text { s }^{3} \text { the mixture viscosity is also cal- } \\
\text { onlated }\end{array}$ \\
\hline VISVAP & $\begin{array}{l}\text { Uses methods developed by Dean and Stie1s, } 18 \\
\text { to calculate the viscosity of nonpolar gas } \\
\text { mixtures at moderate and high pressures }\end{array}$ \\
\hline ZANGOV & $\begin{array}{l}\text { Determines the friction factor for flow of } \\
\text { s1urries in horizontal pipelines via the } \\
\text { Zandi/Govatos correlation }\end{array}$ \\
\hline
\end{tabular}


user specifies to represent the piping system. The code currently has an upper 1 imit of 500 such control volumes.

The user must also create a chemical component library (up to 50 compounds) that may contain more, but definitely not fewer, compounds than are specified in the primary feed and secondary injected feed streams. The library on each compound contains all the information that would be needed for any of the code correlations (e.g., molecular weight; critical temperature, pressure, volume, and compressibility; acentric factor; parachor; and more that will be described in a 1ater section). An indexing system is employed to relate the user-specified feed components to the chemical component 1 ibrary.

In Version 1.0 of FFFAP, no heat can be transferred into or out of a control volume (i.e., the process is adiabatic) and the user does not need to create a control volume, wall component 1 ibrary. However, the code input module and storage capacity currently have the capability for the user to create a wall component library (up to ten materials). In a later edition of FFFAP, the user will have the ability to specify that a control volume be nonadiabatic; then it will be necessary to determine the heat transferred through the control volume wall. In the energy equation, this control volume loss or gain term is currently set equal to zero (Version 1.0 of FFFAP only). An indexing system is again employed to relate the user-specified control volume wa11 composition to the wall component 1 ibrary.

If the user is analyzing an existing piping configuration, the capability exists to directly compare (within the code) experimental and computed values for the fluid pressure, temperature, density, and volumetric flow rate. The user need oniy include the experimental data in the appropriate section of the input deck and specify to which control volume the data applies. In the code output for that volume, the experimental data will also be output. Multiple data sets for a control volume are allowed and the maximum number of data sets is 100 .

One primary feed stream is required. The initial composition (referring to the chemical component library by an index), flow rate, temperature, and pressure of the primary feed stream are required user input. There can be up to ten injected feed streams (i.e., feed streams that are 
injected into the primary feed stream). The information required of the primary feed stream is also needed for each injected stream; additiona1ly, the position in the piping configuration ( $i . e .$. the control volume number) into which the stream is injected must be stated.

The control parameter 1 ibrary is simply a method by which the user can specify which correlations or techniques are to be used in the problem calculations. As evident in Sect. 4.2, many of the user options that are planned for FFFAP are not available in Version 1.0 .

\subsection{Code Usor Input Description}

This section (1ike Appendix A) is not intended to be a user input guide to FFFAP; rather, it is intended to illustrate the structure of the input and to indicate to the user what is required to generate each of the libraries discussed in Sect. 4.1. The primary blocks and the required order in the user-generated input are shown in Fig. 2. The problem heading (Fig. 2) is a user-descriptor for the current problem that will be included in the "starburst" output pages. The remaining six blocks in Fig. 2 refer to the 1 ibraries discussed in Sect. 4.1 .

OANL_DWG 02-5230 ETD

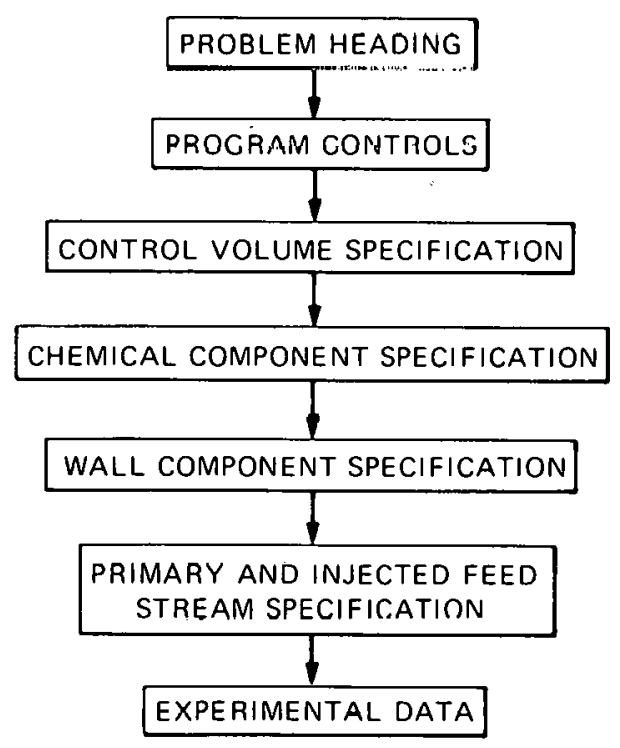

USED IN OUTPUT ONLY

SPECIFIES CONTROL PARAMETER LIBRARY

GENERATES CONTROL VOLUME GEOMETRY LIBRARY

GENERATES CHEMICAL COMPONENT LIBRARY

GENERATES CONTROL VOLUME WALL COMPONENT LIBRARY

SPECIFIES PRIMARY AND INJECTED FEED STREAMS

SPECIFIES AVAILABLE EXPERIMENTAL DATA

Fig. 2. Outline of FFFAP user input requirements. 
The control parameter library is specified after the problem heading. Quite simply, this library is one variable array (ICS) that the user iniitializes in the input. As stated previously, these control parameters (ICS) specify the correlations and calculational techniques to be used in the current problem. An explanation for each of the ICS control variables is given in Table 4. Under the status column of Table 4, if "Not available" is indicated, then that option does not exist in FFFAP-Version 1.0; these options are intended to be added in a later version of FFFAP. The user also has the option of not initializing the ICS array - in which case the code would use the default values given in Table 4.

The fluid system to be analyzed by FFFAP must be fully specified by the user. The system is modeled by user-specified interconnecting fluid volumes (control volumes). The third block in Fig. 2 contains the usergenerated control volume geometry 1ibrary. For each control volume, the information shown in Fig. 3 must be furnished by the user. For instance, given a specific problem, a user decides to model the system with 20 control volumes; then each of the 20 control volumes must be described (the information shown in Fig. 3) by the user. More specific information on the control volume input is given in Appendix A. The FFFAP has a maximum 1 imit of 500 control volumes.

The fourth block in the FFFAP input contains the user-generated chemical component 1 ibrary. This 1 ibrary can contain up to 50 chemical compounds. Each compound must be described by the following information.

Required user input for each chemical compound in the chemical component 1 ibrary

1. Chemical index (i.e., a number between 1 and 50). Note: duplicate indices are not allowed. Exception: if index = 50 (reserved for solids), then only $(1)-(3)$ and the following are needed:

the constants in the solids heat capacity equation where CP = CAP + CPD*T + CPC $^{*} \mathrm{~T}^{2}$ the solid particle mean diameter the solid particle mean density

2. An abbreviated chemical formula ( $\leq 8$ letters and/or numbers). Note: nser shorthand notation for output purposes on1y

3. Chemical name for compound ( $\leq 28$ letters and/or numbers)

4. An indicator for interaction coefficients ( 0 , if none) 
Tab1e 4. Tser-specified control parameter library (FFFAP-Vers-on 1.0)

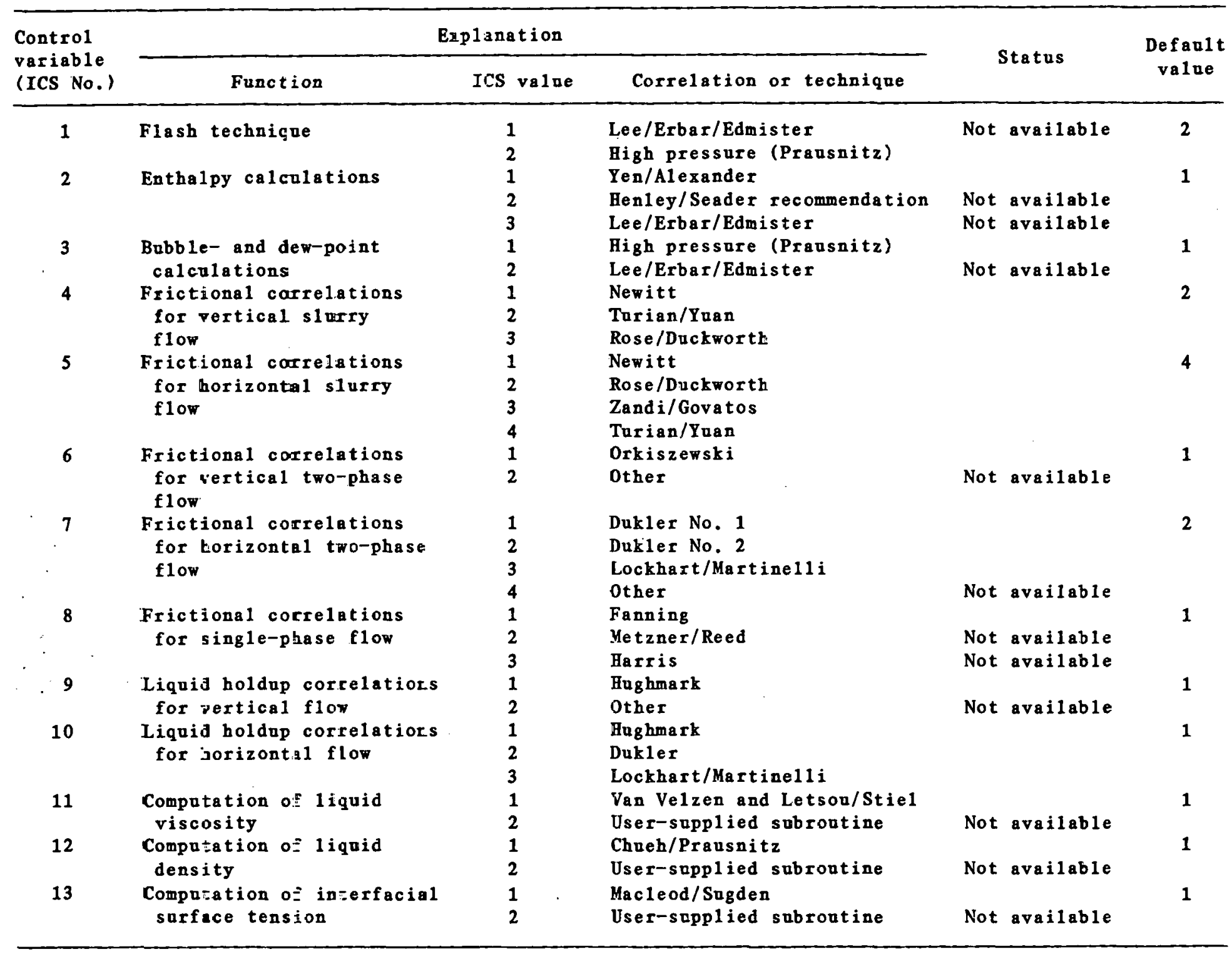


ORNL-DWG 82-5637 ETD

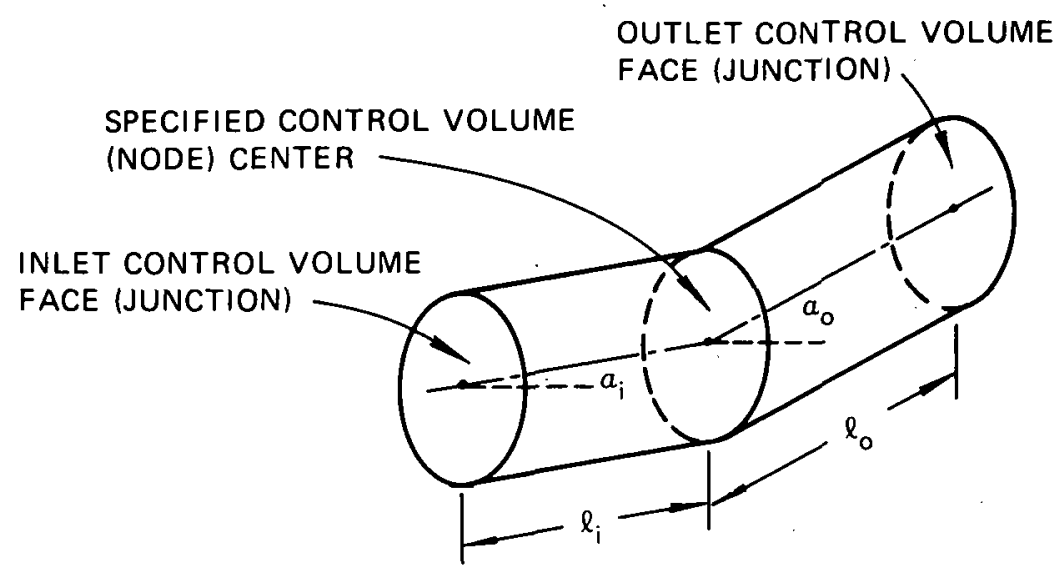

REQUIRED INPUT AT THE INLET AND OUTLET CONTROL VOLUME FACES:

1. FLOW AREA

2. WETTED PERIMETER

3. FLOW RESISTANCE COEFFICIENT

4. RELATIVE ROUGHNESS

5. PIPE INNER RADIUS

6. ANGLE OF INCLINATION, a (RELATIVE TO THE HORIZONTAL)

7. FLOW LENGTH, $\ell$ (FACE TO CONTROL VOLUME CENTER)

ADDITIONAL REQUIRED INPUT FOR EACH CONTROL VOLUME:

1. SPECIFICATION OF CONTROL VOLUME CENTER $(X, Y, Z)$

2. INDICATION OF INJECTED FLOW

3. INDICATION OF AVAILABLE EXPERIMENTAL DATA

4. INDICATION OF NONADIABATIC CONTROL VOLUME

IF THE CONTROL VOLUME IS NONADIABATIC, THE FOLLOWING IS REQUIRED:

1. NUMBER OF PIPE WALL COMPONENTS

2. FOR EACH WALL COMPONENT: INDICATE THE WALL INDEX, THE THICKNESS OF THE WALL, AND THE CONTACT RESISTANCE BETWEEN WALL COMPONENTS

3. TYPE OF EXTERIOR BOUNDARY CONDITION: IF FLUX IS INDICATED, SPECIFY THE FLUX; IF AN EXTERNAL SINK TEMPERATURE AND HEAT TRANSFER COEFFICIENT ARE INDICATED, THEY MUST BE SPECIFIED.

Fig. 3. Required user input for each control volume. 
5. An indicator for vapor pressure model (Lee-Kesler correlations $^{3}$ if $=0$; Antoine correlations if $=1$ )

6. Molecular weight

7. Critical temperature

8. Critical pressure

9. Critical specific volume

10. Critical compressibility

11. Pitzer's acentric factor

12. The normal boiling point

13. The heat of vaporization at the normal boiling point

14. The parachor

15. Constants in the ideal gas heat capacity equation where $\mathrm{CP}=\mathrm{CPA}+\mathrm{CPB} * \mathrm{~T}+\mathrm{CPC} * \mathrm{~T}^{2}+\mathrm{CPD} * \mathrm{~T}^{3}$

16. Constants in the van Velzen liquid visoosity equation whore $\log _{10}(v i \cos i t y)=A(1 / T-1 / B)$

17. The solubility parameter

18. The 1 iquid molar volume

19. If the indicator in (5) $=1$, Antoine vapor pressure equation coefficients where $\ln$ (vapor pressure) $=A-B / T+C$

20. Interaction coefficients of this compound with other compounds [needed if indicator in (4)>0]

The one exception is for a chemical index equal to 50 , which is reserved for solids. More specific information on the input structure is given in Appendix A.

The wall component 1 ibrary is used if heat can be transferred into or out of a control volume (i.e., a nonadiabatic process that will be indicated by the input for each control vol uma, Fig. 3). As notod proviously, FFFAP-Version 1.0 is 1 imited to the adiabatic process; therefore, generating a wall component 1 ibrary is not necessary. The library can contain up to ten materials, and each material must be dcscribed by the following information.

Required user input for each material in the wall component 1 ibrary

1. Material indox ( $i . a_{.}$a numbur botween 1 and 10 ) Note: duplicate indices are not allowed

2. User name for the material ( $\leq 20$ letters and/or numbers)

3. Constants in the thermal conductivity equation for the material where

$K=A_{1}+A_{2} * T+A_{3} * T^{2}+A_{4} * T^{3}+A_{3} * T^{4}$ 
By specifying the feed streams (primary and injected), the FFFAP user is also specifying the boundary conditions for the model. The initial boundary conditions are indicated by the user-specified primary feed stream. The required input for the primary feed stream is as follows:

\title{
Required user input for
} the primary feed stream

1. The number of components

2. The feed temperature

3. The feed pressure

4. For each component

(a) the chemical index (referring to a compound in the chemical component 1 ibrary

(b) the mass flow rate

The fluid system may have injected side streams (for example, an injected quench gas or a recycle stream), and the user may include these streams in the problem. The required user input for each injected feed stream is as follows:

\author{
Required user input for each \\ injected feed stream
}
1. The feed position (i.e., the con- trol volume into which the stream is injected)

2. The number of components

3. The feed temperature

4. The feed pressure

5. For each component
(a) the chemical index (referring to a compound in the chemical component 1 ibrary)
(b) the mass flow rate

There is a 1 imit of ten injected streams in FFFAP-Version 1.0 .

The 1 ast block in the outline in Fig. 2 contains user-specified

experimental data. If the user is analyzing an existing piping configuration and flow system, experimental data (fluid temperature, pressure, etc.) may be available; if so, this block allows the user to directly compare (in the code output) computed and observed values. The user has a 1 imit of 100 experimental data sets that can be input (multiple sets can 
be input for one control volume); the input requirements for each data set are as follows:

Required user input for each experimental data set

1. The position in the fluid system (i.e., the control volume in which the data was taken)

2. Any or all of the following:

(a) pressure

(b) temperature

(c) volumetric flow rate

(d) density

\subsection{Conde Dutpnt Description}

A brief out1ine of the FFFAP-Version 1.0 code output is presented in Tab1e 5. For every problem solved by FFFAP, there will be $13+n$ pages of code generated output (where $n=$ number of control volumes specified by the user).

Tab1e 5. Outline of FFFAP-Version 1.0 output

\begin{tabular}{|c|c|}
\hline Page & Explanation \\
\hline $\begin{array}{l}1 \\
2 \\
3\end{array}$ & $\begin{array}{l}\text { Echo of the user-defined input stream } \\
\text { Starburst with input heading } \\
\text { User-specified program controls }\end{array}$ \\
\hline 3 & $\begin{array}{l}\text { User-specitied program controls } \\
\text { Chemical library }\end{array}$ \\
\hline 5 & Plpe wall library \\
\hline 6 & Experimental data sets \\
\hline 7 & Model geometry and noding \\
\hline 8 & Mode1 geometry and noding (continned) \\
\hline 9 & Primary feed stream \\
\hline 10 & Injected feed streams \\
\hline 11 & Initial condition (state) of the primary feed stream \\
\hline 12 & Starburst with heading \\
\hline $13-12+n$ & $\begin{array}{l}\text { Node-by-node thermal-hydraulic analysis of the speci- } \\
\text { fied model ( } n=\text { number of control volumes specified } \\
\text { by user) }\end{array}$ \\
\hline $13+n$ & Final condition (state) of the primary feed stream \\
\hline
\end{tabular}


After reading each card image of the user-defined input stream, the INPUT module will output the card image (page 1 of the output). INPUT checks the order of the input stream ( $i . e_{.}$, it checks for the required sequence of the card images); if it finds card images out of sequence, the code will terminate the job at that point. Each card image has a sixdigit sequential identifier in the first ten columns that INPUT uses to check the order. An example of page 1 output is shown in Fig. 4. All examples of FFFAP output are taken from sample problem 5 (Appendix B).

Starburst output pages [Fig. 5 (FFFAP pages 2 and 12)] are simply eye catchers and separators. These pages begin the two primary parts of the FFFAP output. Pages 3-10 contain the user-generated FFFAP 1 ibraries in a more readable form than page 1 . These 1 ibraries are output for two reasons: (1) problem definition and (2) aiding the user in verifying the code inpat. Figure 6 illustrates the control parameter library output (FFFAP page 3 ). Figure 7 presents the chemical component 1 ibrary output (page 4). Figure 8 shows pages 5 and 6 of sample problem 5 (pipe wall component 1 ibrary and experimental data sets, respectively); for this problem, there were no entries for these two 1 ibraries. Pages 7 and 8 of the output (Fig. 9) contain the user-specified control volume 1 ibrary. The feed stream specifications are output on pages 9 and 10 (Fig. 10) for the primary and injected feed streams, respectively.

Pages 11 and $13+n$ (the 1 ast page) contain the initial and final state (condition) of the primary feed stream. The initial state of the fluid (page 11) applies at the front face (junction) of the first control vo1ume; this is the initial fluid boundary condition. The final state of the fluid (page $13+n$ ) applies at the rear face of the nth control volume and, thus, is the final state of the fluid for the user-specified problem. If only the initial and final states of the fluid are desired by the user, then pages 11 and $13+n$ are sufficient; but the user still receives a bonus of $n$ pages of node-to-node calculations. The output format of pages 11 and $13+n$ is dependent on the state of the fluid, and the examples (Figs. 11 and 12) from sample problem 5 show both extremes. The output for these 


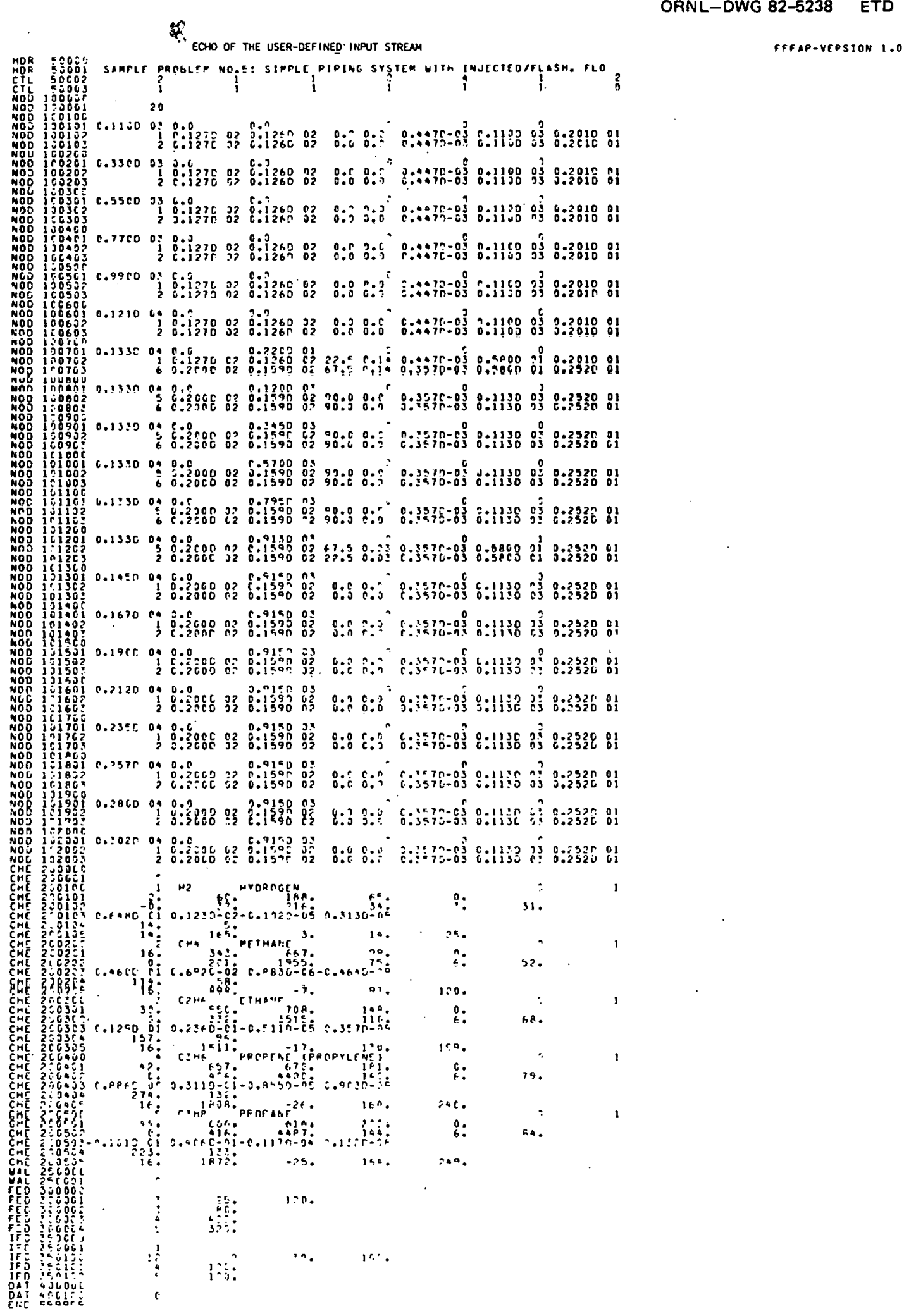

Fig. 4. Example of FFFAP page 1 outpat. 


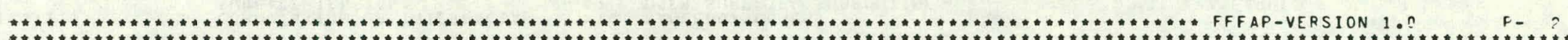

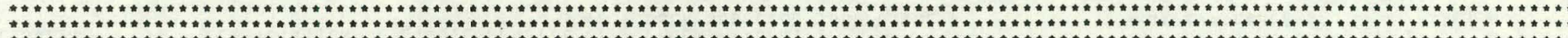

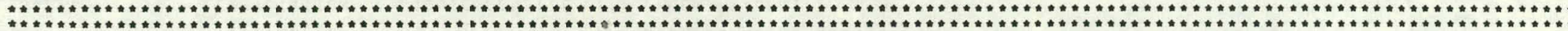

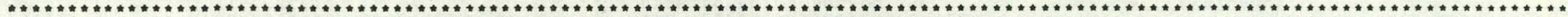
MH

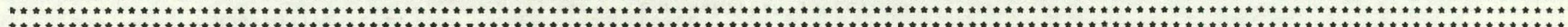

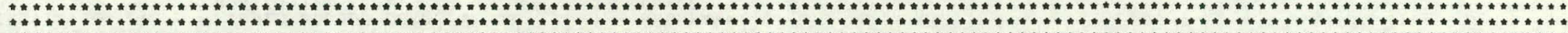

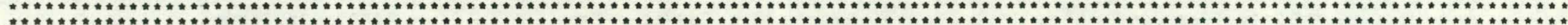

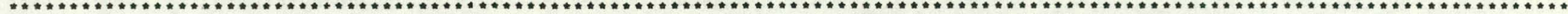

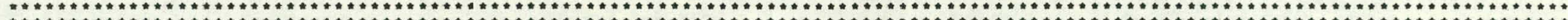
t*

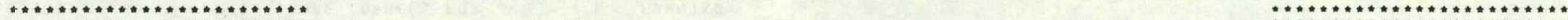

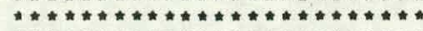
M

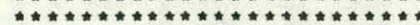

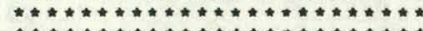

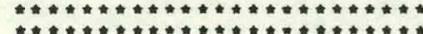

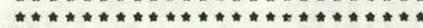

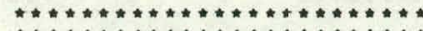

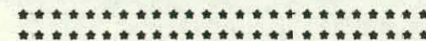

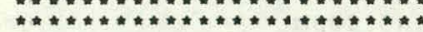

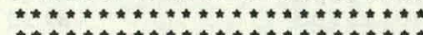

FLASHING FLUID FLOW ANALYSIS PROGRAM

$$
\text { MOOEL TITLE: }
$$

SAMPLE PROBLEM NO.5: SIMPLE PIPING SYCTEM HITH INJECTED/FLASH. FLO

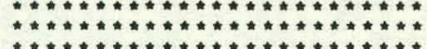
m

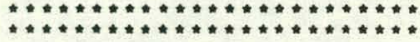

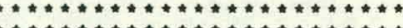

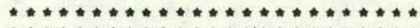

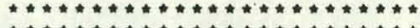

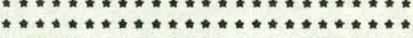

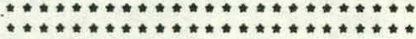
t. +on

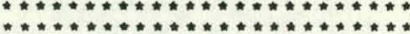

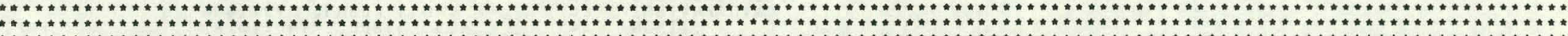

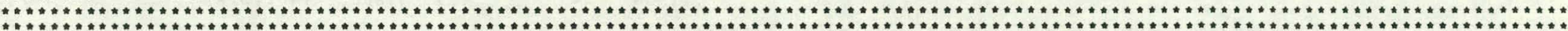

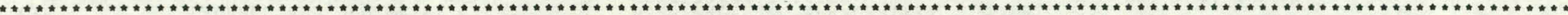

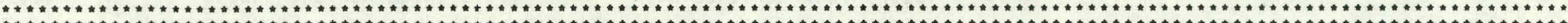

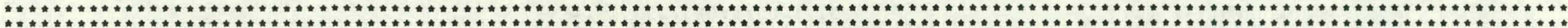
:

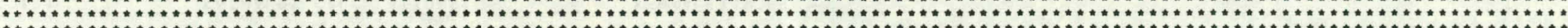

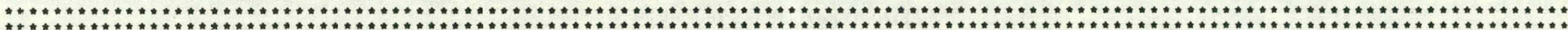

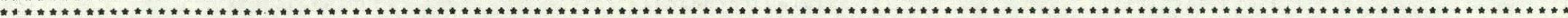

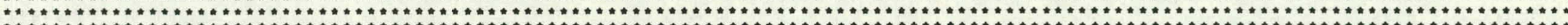

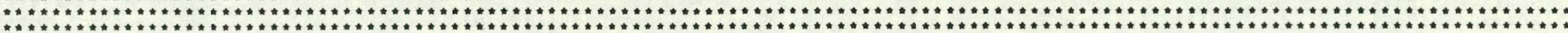

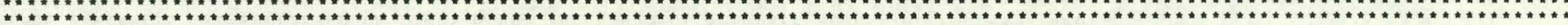

Fig. 5. "Starburst" output page. 


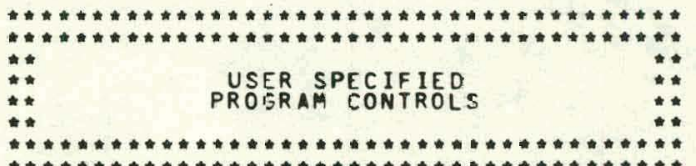

CONTROL VARIABLES ARE SPECIFIED ON CARDS 50002 ANR 50003 GF THE USER SENERATED PROGRAM INPUT. CONTROL

ICS (1)

$\operatorname{Ics}(2)$

FLASH TECHNIQUE:

EXPLANAT:ON

I CS $(3$

ENTHALPY CALCULATIONS:

$=1$
$=2$
$=2$

$=1$
$=2$
$=2$
$=2$

BUBBLE ANO DEW POINT CALC: =1 HIGH PRESSURE (PRAUSNITZ)

ICS (4)

ICS(5)

ICS (6)

I CS (7)

$\operatorname{ICS}(8)$

$\operatorname{ICS}(9)$

ICS(10)

ICS(11)

ICS(12)

I CS (13)
FRICTIONAL CORREL FOR
VERTICAL SLURRY FLOW:

FRICTICNAL CORREL. FOR
HORIZONTAL SLURRY FLOH:

FRICTIONAL CORREL. FOR
VERTICAL TWO-PHASE FLOW: FRICTIONAL COPREL FOR
HORIZONTAL THO-PHASE FLOW:

FRICIICNAL CORRELL: FOR
SINGLE PHASE FLOH:

LIQUIO HOLDUP CORREL. =OR LIQUIC HO-DUP CORREL. =OR
HORIZCNTA. FLOW:

COMPU-ATION OF LIGUID DENSITY $=$

COMPUTATION OF INTERFACIAL
SURFAEE TENSION:
COMPUTATION OF LIDUIO
VISCOSITY:
$=1$ DUKLFR MO.1

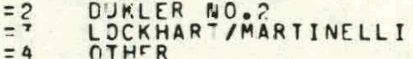

$=1$
$=2$
$=2$
$=3$

$=1$ MUGHARK

$=1$ HUGHMARK

LUKLER

$=1$
$=2$
$=2$

CHUEHAFPAJSNITZ
IJSER SUPPLIED SUBROUTINE

MACLEODSSUGEN $\begin{array}{ll}=1 & \text { ORKISZELSKI } \\ =2 & \text { OTHER }\end{array}$
FFF AP-VERSION 1.0

D. ?

Fig. 6. Control parameter 1ibrary output.

\begin{tabular}{|c|c|c|c|}
\hline & TATUS & $\begin{array}{l}\text { INPUT } \\
\text { VALUE. }\end{array}$ & $\begin{array}{l}\text { DEFAULT } \\
\text { VALUE }\end{array}$ \\
\hline Nor & AVAILARLE & $?$ & ? \\
\hline $\begin{array}{l}\text { NOT } \\
\text { NOT }\end{array}$ & $\begin{array}{l}\text { AVAILAPLE } \\
\text { AVAILABLE }\end{array}$ & 1 & 1 \\
\hline NOT & AVAILARLE & 1 & 1 \\
\hline & & 4 & 4 \\
\hline TנN & AVAILARLE & 1 & $!$ \\
\hline & & 2 & 2 \\
\hline NOT & RVAILAELE & & \\
\hline $\begin{array}{l}\text { NOT } \\
\text { NOT }\end{array}$ & $\begin{array}{l}\text { AVAILAELE } \\
\text { IVAILARLE }\end{array}$ & 1 & 1 \\
\hline NOT & $\triangle V A I L A E L E$ & 1 & 1 \\
\hline & & 1 & 1 \\
\hline NOT & AVAILABLE & 1 & ! \\
\hline NOT & AVAILARLE & 1 & 1 \\
\hline & & 1 & 1 \\
\hline
\end{tabular}

VOT AVAILARLE 
THERE IS A TOTAL OF 5.CHEMICAL COMPOUNOISJ IN THE CURRENT LIBRARY.

N INDEX FORMULA

$1 \quad 1 \quad H 2$

$2 \quad 2 \mathrm{CH} 4$

$33 \mathrm{C} 2 \mathrm{HG}$

$4.3 H_{6}$

$5 \quad 5 \quad C 3 H R$

MAME.WT. TCRIT PCRIT VCRIT ZCRIT

HYDROGEN OOMEGA TBOIL HFGB PARAEHOR SOL VML

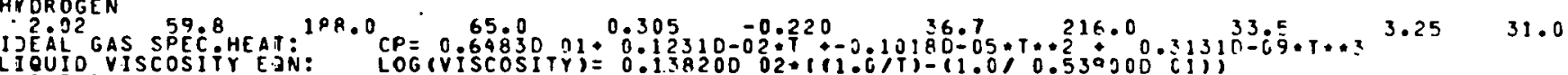

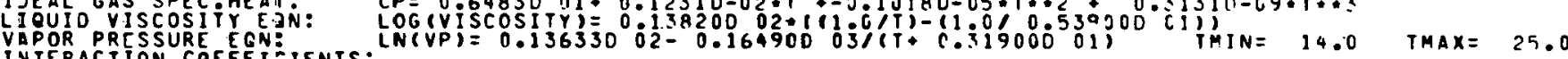
I.NTERACTION COEFFIEIENTS: ALL.EQ.0.0. EXCEPT FOR THOSE NOTEO.

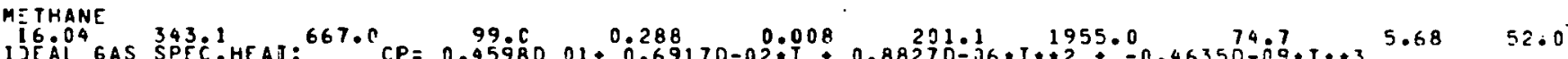

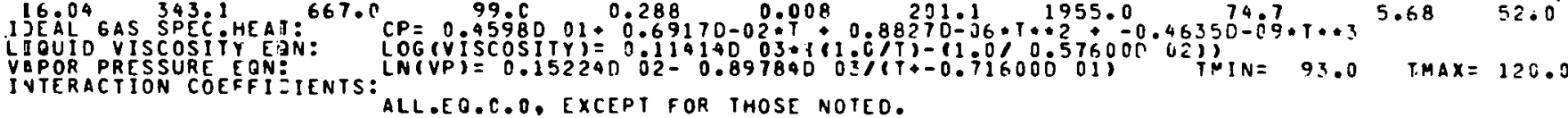

EITANE ALL.EO.C.O. EXCEPT FOR THOSE NOTED.

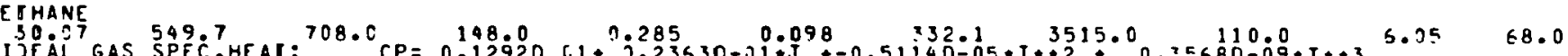

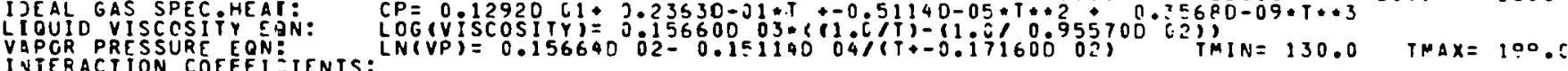
IVTERACTION COEFFIEIENTS: ALL.EO.0.0. EXCEPT FOR THOSE NOTED.

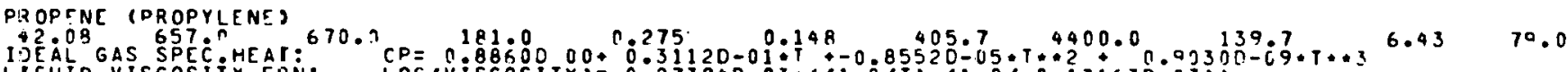

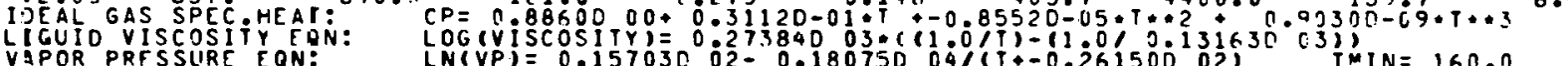

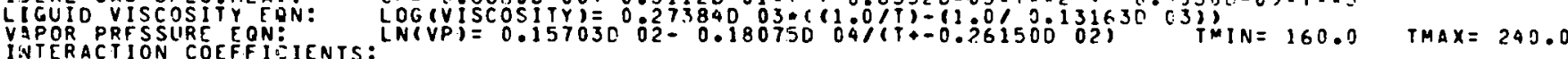
ALL.EO.0.O, EXCEPT FOR THOSE NOTEO.

DROPANE

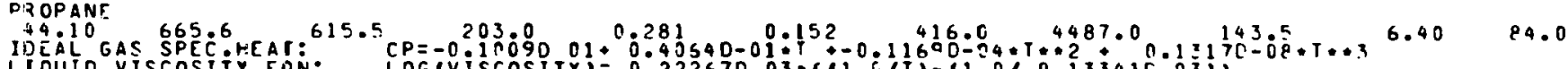

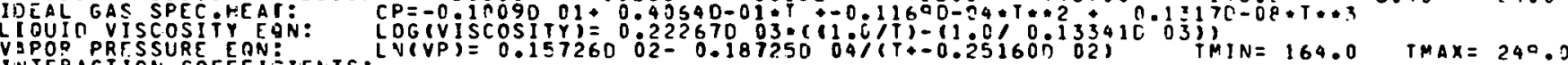
INTERACTION COEFFIEIENTS: ALL.EQ.0.0. EXCEPT FOR THOSE NOTED.

Fig. 7. Chemical component 1 ibrary output. 
THERE IS A TOTAL OF O PIPE YALL COMPONENTS IN THE CURREN" LIBEARY

THERMAL CONDUCTIWITY TEMPERATURE $=11$

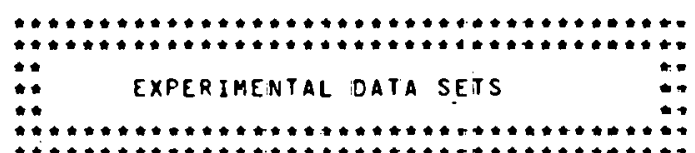

FFFAP-VERSION 1.0

THERE IS A TOTAL OF O EXPERIMENTAL. DATA SET(S) IN THE CUERENT JOB INPUT.

N NODE. PRESSURE TIMPERATURE FLOU

Fig. 8. Pipe val1 component 1 ibrary and experinental data sets output pages. 


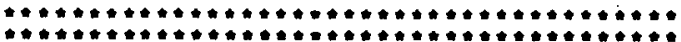 \\ MODEL GEOMETRY ANO NOOING \\ $\because$

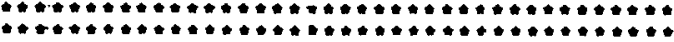

FFFAP-VFRSION 1.0

THERE IS A TOTAL OF 20 CONTROL VOLUMES IN THE CURRENT MODEL

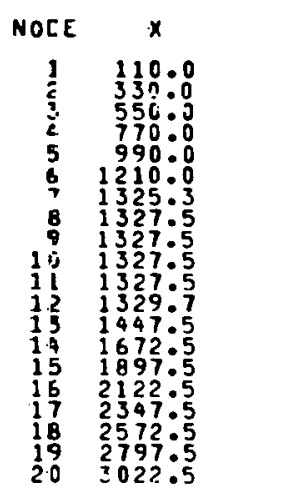

$\begin{array}{lrr}r & 2 & J I \\ 0.0 & 0: 0 & 1 \\ 0: 0 & 0: 0 & 1 \\ 0: 0 & 0: 0 & 1 \\ 0: 0 & 0: 0 & 1 \\ 0: 0 & 0: 0 & 1 \\ 0: 0 & 0: 0 & 1 \\ 0: 0 & 2: 2 & 1 \\ 0: 0 & 120: 0 & 5 \\ 0: 0 & 345: 0 & 5 \\ 0: 0 & 57 n: 0 & 5 \\ 0: 0 & 795: 0 & 5 \\ 0: 0 & 912: 0 & 5 \\ 0: 0 & 915: 0 & 1 \\ 0: 0 & 915: 0 & 1 \\ 0: 0 & 915: 0 & 1 \\ 0: 0 & 915: 0 & 1 \\ 0: 0 & 915: 0 & 1 \\ 0: 0 & 915: 0 & 1 \\ 0: 0 & 915: 0 & 1 \\ 0: 0 & 915: 0 & 1\end{array}$

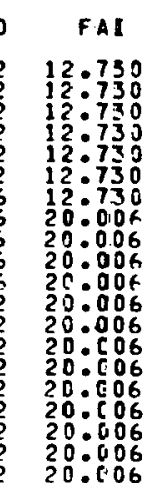

FAO WPI HPO
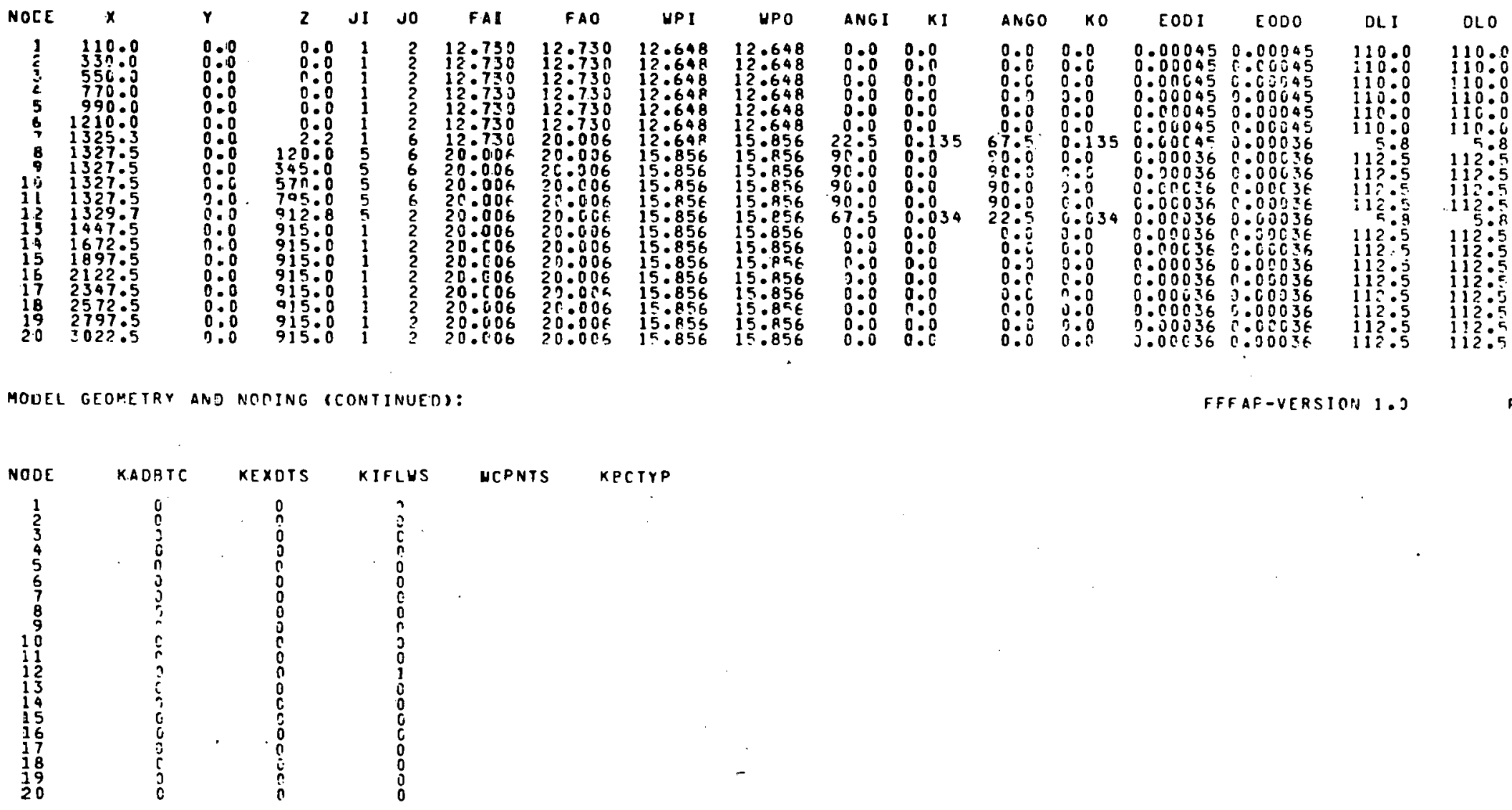

Fig. 9. Control volume 1ibrary output. 


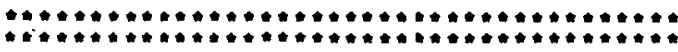

ORNL-DWG 82-5244 ETD

: PRIMART and INJECTED fEed STREAHS

:*

PRIMARY FEED STREAM:

THERE IS A TOTAL OF 3 CHEMICCAL COMPOUNOCS) IN THE CURRENT MODEL

EED STREAH PRESSURE = $100 . \mathrm{C}^{2}$ BSIAEG F

N INOEX FORMULA USER CHEMICAL NAME

$\begin{array}{llll}1 & 3 & \text { C2HG } & \text { ETHANE } \\ 2 & \vdots & \text { CYHG } & \text { PROPENE (PROPYLENE) } \\ 3 & 5 & \text { C } 3 H B & \text { PROPANE }\end{array}$

MASS FLOU RATE

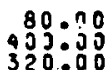

INJECTED FEED STREAMS:

THERE IS A TOTAL OF I IN-ECTED FEED STREAMS IN THE CURR:NT MJOE.

STREAM NO 1 IS INJE.TEC IN NODE 12 ANO HAS A TCTAL OF ? CHEMICAL COMPOUNOS.
N INDEX FORMULA
USER CHEMICAL NAM:
MASS FLOU RATE
$\begin{array}{lll}1 & 4 & C 3 H 6 \\ 2 & 5 & 53 H 8\end{array}$
PROPENE (PROPYLENE)
PROPANE
100.90

Fig. 10. User-specified feed streams. 


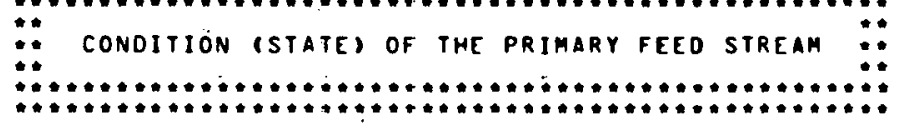

\begin{tabular}{|c|c|c|c|c|c|c|c|}
\hline$N$ INCEX & FORMUL & USER CHEMICAL NAME & $\begin{array}{l}\text { FLON RATE } \\
\text { (LESIMINS }\end{array}$ & FREIGHT & $\begin{array}{l}\text { MOLECULAR } \\
\text { WEIGHT }\end{array}$ & $\begin{array}{l}\text { FLOY RATE } \\
\text { (LBMOLEININN) }\end{array}$ & FRACTE \\
\hline $\begin{array}{l}3 \\
4 \\
5\end{array}$ & $\begin{array}{l}\text { C2HG } \\
\text { C } 3 H G \\
\text { C } 3 H A\end{array}$ & $\begin{array}{l}\text { ETHANE } \\
\text { PROPENE (PROPYLENE) } \\
\text { PROPANE }\end{array}$ & $\begin{array}{l}80.000 \\
400005 \\
320.00\end{array}$ & $\begin{array}{l}0.10000 \\
0.5000 \\
0.4050\end{array}$ & $\begin{array}{l}39.07 \\
42: 08 \\
44: 10\end{array}$ & 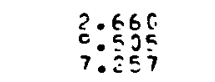 & $\begin{array}{l}0.1370 \\
3: 4894 \\
9.3736\end{array}$ \\
\hline
\end{tabular}

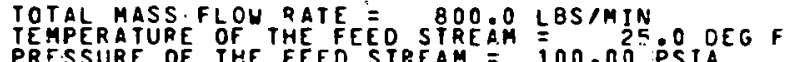

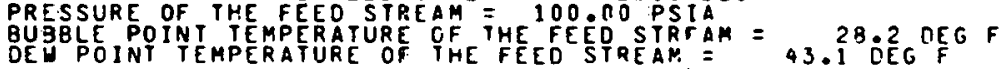

STATE OR CONOITION OF THE FEED STREAM : SURCOOLEO LIOUIO

HEAT CONTENT OF IHE LIQUID $=-119547.66$ BTUMMIN $=-149.43$ RTUMLR

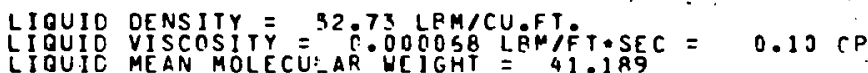

Fig. 11. Initial state of the feed stream. 


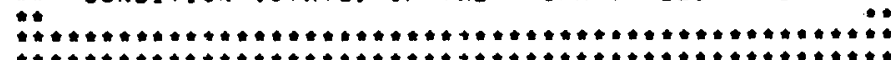

AME

\section{TOTAL MASS FLOU RATE}

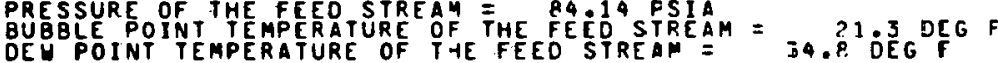

THE FEED STREAM IS THO-PHASE ANO HAS THE FOLLCMIMG VAPOR/LIOUIO SPLIT:

\begin{tabular}{|c|c|c|c|c|c|c|c|c|}
\hline COMPONENT & $\begin{array}{l}\text { FLOURATE } \\
\text { ULSIPINI }\end{array}$ & $\begin{array}{l}\text { ME TGHT } \\
\text { FRACTION }\end{array}$ & $\begin{array}{l}\text { FICOU RATE } \\
\text { ILEMOLEMINS }\end{array}$ & FQACTEION & 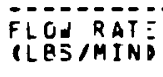 & $\begin{array}{l}\text { FE TGHT } \\
\text { FRACTION }\end{array}$ & 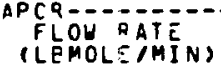 & FRACTIOA: \\
\hline $\begin{array}{l}\text { ETHANE } \\
\text { PRGPENE (PROPYLENE) } \\
\text { PROPANE }\end{array}$ & $\begin{array}{r}69.67 \\
479: 22 \\
405: 28\end{array}$ & 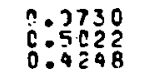 & $\begin{array}{l}2: 317 \\
11: 38: 3 \\
9: 191\end{array}$ & $\begin{array}{l}0.1012 \\
0: 4974 \\
0.4014\end{array}$ & $\begin{array}{l}10.33 \\
20: 78 \\
14: 72\end{array}$ & $\begin{array}{l}0.2254 \\
0.4535 \\
0.3211\end{array}$ & 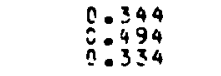 & $\begin{array}{l}0.2925 \\
0.4211 \\
0.284 E\end{array}$ \\
\hline
\end{tabular}

\begin{tabular}{|c|c|c|c|c|}
\hline $\begin{array}{l}\text { FEOU RATE } \\
\text { IOBSIMINE }\end{array}$ & $\begin{array}{l}\text { YEIGHT } \\
\text { FRACTION }\end{array}$ & $\operatorname{MOL}_{U E C Y U T}$ & $\begin{array}{l}\text { FLOH RATE } \\
\text { (LEROLEIMIN, }\end{array}$ & FRACTIION \\
\hline $\begin{array}{r}83.00 \\
590: 00 \\
420: 05\end{array}$ & $\begin{array}{l}0.0800 \\
0.50 \% 00 \\
0.4200\end{array}$ & $\begin{array}{l}30.37 \\
42: 38 \\
4+.10\end{array}$ & $\begin{array}{r}2.660 \\
11: 882 \\
9526\end{array}$ & $\begin{array}{l}0.1105 \\
0.4037 \\
3: 3959\end{array}$ \\
\hline
\end{tabular}

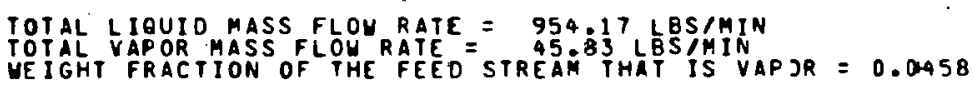

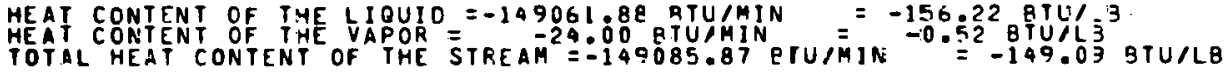

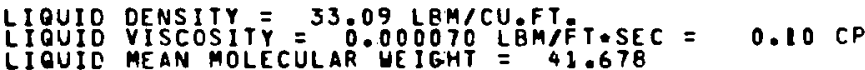

VAPOR DENSITY $\overline{\bar{Y}}=0.7 \mathrm{7C83}$ LEMACU FTF

VAPOR MEAN MOLECULAR WEIGHT $=39.877$
VAPOR COMPRESSIBILITY FACTOR $=0.8969$

VAPOR/LIQUIO INTERFACIAL SURFACE TENSION $=0.599050-02$ LBF/FT $=8.741$ OYNE/CH

IHCOO2I STCP

Fig. 12. Final state of the feed streem. 
pages genera11y takes the following form:
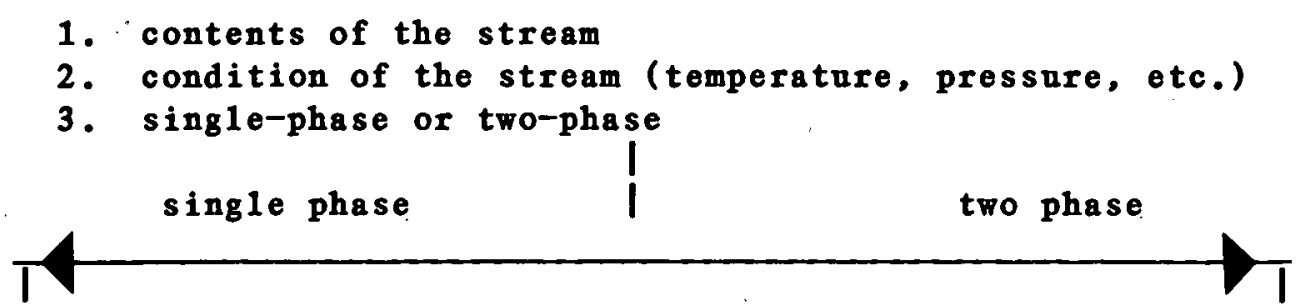

4. heat content of the phase

4. vapor/liquid split

5. phase properties (density.

5. mass flows and fraction viscosity, etc.) vaporized

6. heat content of the phases

7. Iiquid properties

8. vapor properties

Page 12 is a starburst that signals the beginning of the node-by-node therma1-hydraulic analysis of the user-specified model. Each subsequent page contains a complete analysis for the user-specified control volumes. Two examples of the output are given in Figs, 13 and 14 (for the first and last control volumes in sample problem 5). Again the output format is dependent on the state of the fluid (at the specified control volume center), and the output generally takes the following form:

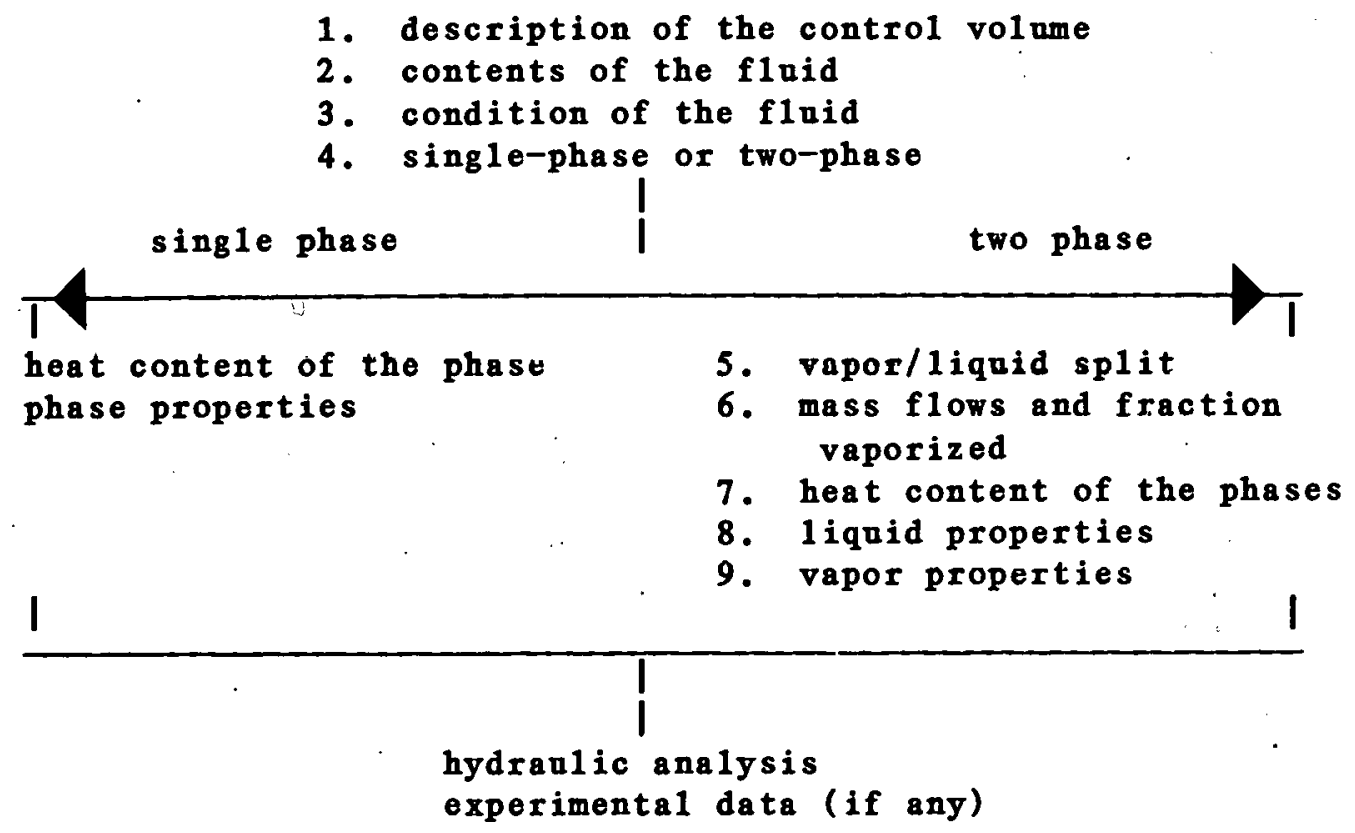

Figures 13. and 14 illustrate the normal nodal output; however, for the situation where a side stream flow is injected into the primary stream (as in sample problem 5), the nodal output is more complex. In addition to 


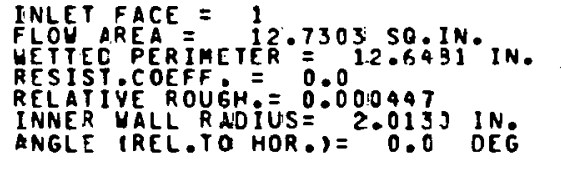

EXPERIMENTAL DATA: NO
INJECTEDTFLOU: ND
ADIABATIC:

CONTENTS OF THE PRIMARY STAEAM: I COMPONENTS
N JNDEX
FOR KULA
USER CHEMICAL NAME
$\begin{array}{lll}1 & 3 & \text { C2HE } \\ 2 & 4 & \text { C } 3 H E \\ 3 & 5 & \text { C3H. }\end{array}$
ETHANE
PROPENE
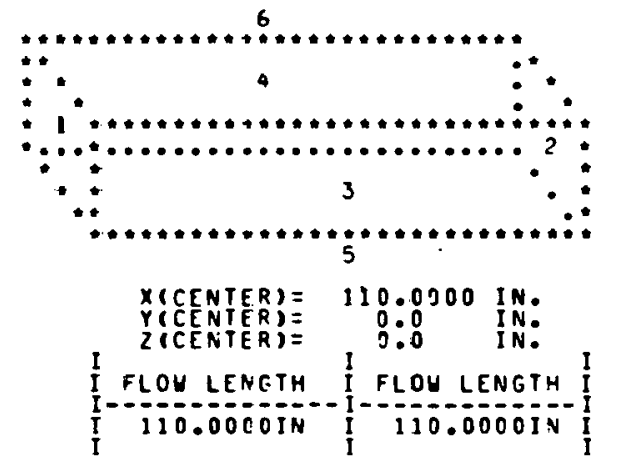

OUTLET

RETIED SER JMETER $=12.6481$

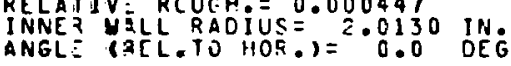

\section{IOTAL MASS FLOU RATE $=$ POA OO LBSTIN}

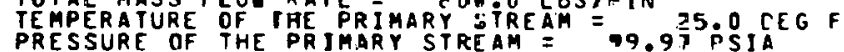

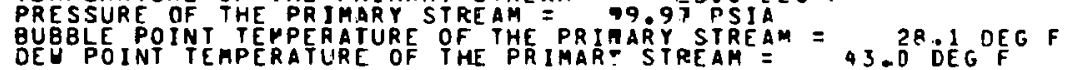

\begin{tabular}{|c|c|c|c|c|}
\hline $\begin{array}{l}\text { FLOU RATE } \\
\text { (LES/MIN) }\end{array}$ & $\begin{array}{l}\text { YEIGHT } \\
\text { FRACTION }\end{array}$ & $\begin{array}{l}\text { MOLECULAR } \\
\text { WEIGHT }\end{array}$ & $\begin{array}{l}\text { FLOW RAIE } \\
\text { (LEMOLEJMIN) }\end{array}$ & FRACTION \\
\hline $\begin{array}{r}80.09 \\
450: 30 \\
320: 00\end{array}$ & $\begin{array}{l}0.1000 \\
0.5000 \\
0.4005\end{array}$ & $\begin{array}{l}32.87 \\
42.88 \\
44.18\end{array}$ & $\begin{array}{l}2.660 \\
70605 \\
7.257\end{array}$ & $\begin{array}{l}3.1370 \\
3: 4994 \\
0.3736\end{array}$ \\
\hline
\end{tabular}

STATE OR CONOITION OF THE PFIMARY SIREAM : SUBCCOLED LIJOUID

MEAT CONTENT OF THE LIOUID $=-119547.66$ PTUIMIN $=-1.0 .43$ BPTU/LP

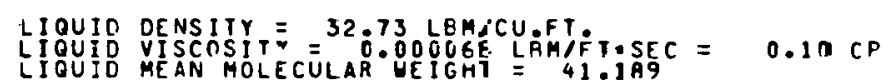

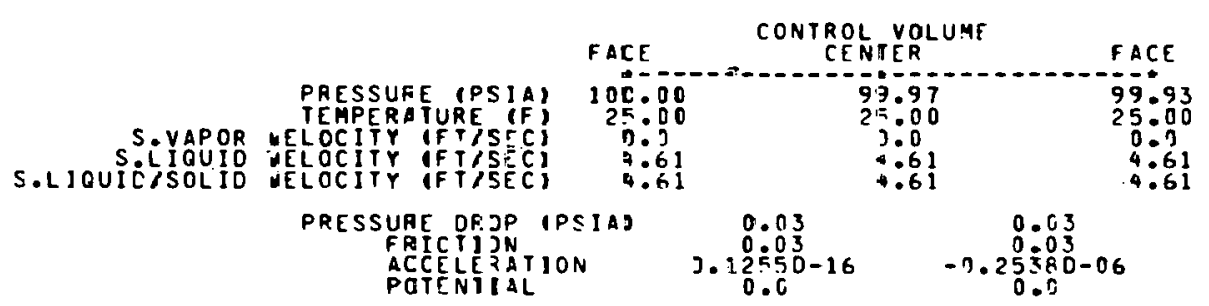

Fig. 13. Example of nodal analysis (f1uid, single-phase). 
FFFAP-VERSION 1.0

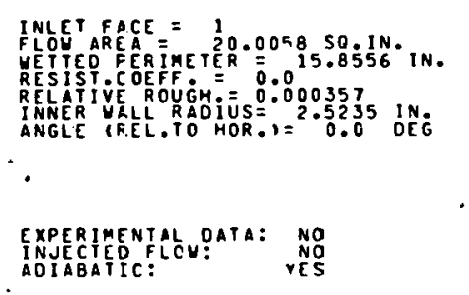

CONTENTS OF THE PRIMARY STREAM: I E CRMPONENTS,

USEP CHËICAL MAME

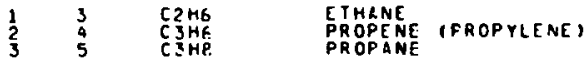

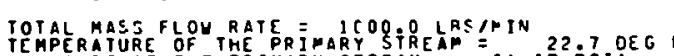

PEMPERATURE OF THE PRIMARY STREAP = 49.1227 PEG

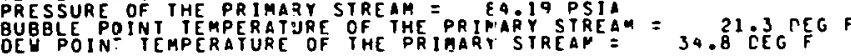

THE PRIMARY STREAM IS TUO-PMASE ANO HAS TME EOLLOUING VAPCRILIQUIO SOLIT:
COMPONENT

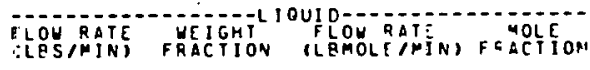

ETHAHE TPROPYLENE)

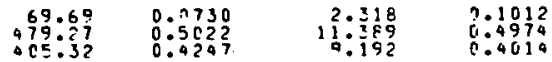

TOTAL LIJUIT MASS FLCW RATE = 954.

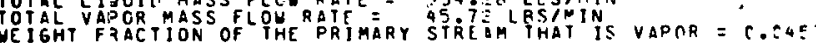

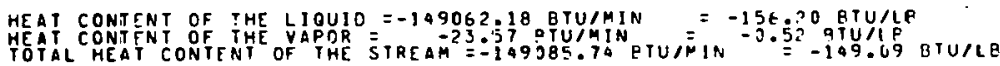

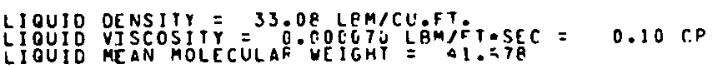

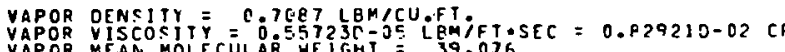

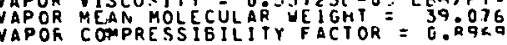

VAPOR/LTGUID INTERFACIAL SURFACE TENSION $=0.5989$-0-03 LPF/FT $=9.733$ CYNE/CM

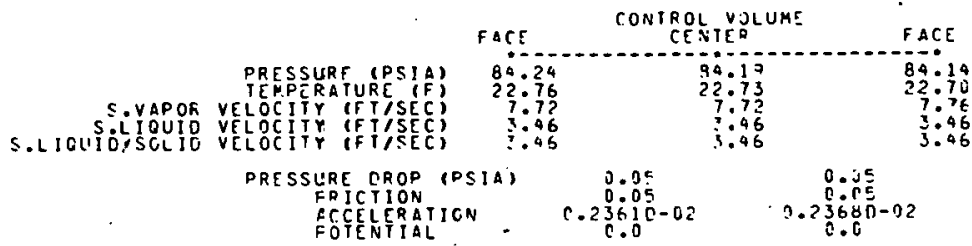

Fig. 14. Example of nodal analysis (f1uid, two-phase).

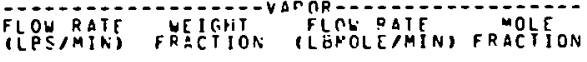

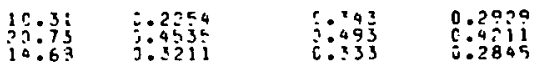

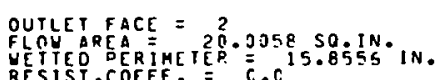

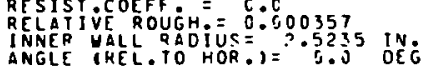

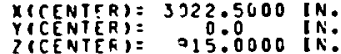

$$
\begin{aligned}
& \text { FLOV LENGTH }
\end{aligned}
$$


the normal nodal output, the state(s) of the injected feed stream and the combined streams is also output for that control volume (an example of this sitation is shown on page 24 of the case 5 outpat).

\subsection{Code Applications}

Version 1.0 of FFFAP can be used to analyze multicomponent, multiphase, Newtonian, adiabatic flow behavior in piping systems. The fluid may be single-phase (vapor or liquid), may contain solids, may be flashing (vaporizing), and there may be injected side streams. Although the specific application objective for this code is the high-pressure coal liquefaction letdown process, the code is generalized and can be applied to any piping and fluid system. In the future, the Newtonian and adiabatic restrictions will be removed by proposed model improvements and a subsequent FFFAP version.

However, the universal applicability of FFFAP is questionable because most of the correlations (physical property and thermodynamic) apply to nonpolar compounds. For instance, the results from the code in an app1ication to a water or methanol flow system should be considered suspect nntil it can be verified experimentally or by some other means.

The code applicability will be demonstrated via five sample problems. The piping system to be studied is relatively simple (a schematic of the system is shown in Fig. 15). Flow in the system is from point 1 to point 2 (Fig. 15), and the fluid is a mixture of ethane, propene, and propane. The five case descriptions are given in Table 6 . The initial boundary conditions for the fluid at point 1 in Fig. 15 are known and are given in Table 6. The only difference between cases 1-4 is the initial temperature of the fluid. Case 5 contains an additional twist: the initial conditions at point 1 are the same as for case 4 , but a side stream has been introduced into the upper elbow in the piping system. The primary objective in these sample problems will be to determine the overall pressure drop between points 1 and 2 (Fig. 15) and to determine the final state of the fluid at point 2 .

In these sample problems, 20 control volumes (nodes) are used to represent the piping system in Fig. 15. The noding representation of the 
Table 6. Sample problem descriptions from piping system. (Fig. 15)

\begin{tabular}{|c|c|c|c|c|}
\hline $\begin{array}{l}\text { Case } \\
\text { No. }\end{array}$ & Fluid & $\begin{array}{l}\text { Injected } \\
\text { fluid }\end{array}$ & Condition of feed at 1 & $\begin{array}{l}\text { Condition of } \\
\text { injected feed }\end{array}$ \\
\hline 1 & $a$ & None & $\begin{array}{l}\text { Subcooled } 1 \text { iquid at } 258.2 \mathrm{~K} \text { and } 689.5 \mathrm{kPa} \\
\left(5^{\circ} \mathrm{F} \text { and } 100 \text { psia) }\right.\end{array}$ & N/A \\
\hline 2 & $a$ & None & $\begin{array}{l}\text { Superheated vapor at }, 283.2 \mathrm{~K} \text { and } 689.5 \mathrm{kPa} \\
\left(50^{\circ} \mathrm{F} \text { and } 100 \text { psia) }\right.\end{array}$ & N/A \\
\hline 3 & $a$ & None & $\begin{array}{l}\text { Two-phase mixture at } 273.7 \mathrm{~K} \text { and } 689.5 \mathrm{kPa} \\
\left(33^{\circ} \mathrm{F} \text { and } 100 \text { psia) }\right.\end{array}$ & N/A \\
\hline 4 & $a$ & None & $\begin{array}{l}\text { Subcooled liquid at } 269.3 \mathrm{~K} \text { and } 689.5 \mathrm{kPa} \\
\left(25^{\circ} \mathrm{F} \text { and } 100 \mathrm{psia}\right)\end{array}$ & $\mathrm{N} / \mathrm{A}$ \\
\hline 5 & $a$ & $b$ & $\begin{array}{l}\text { Subcooled liquid at } 269.3 \mathrm{~K} \text { and } 689.5 \mathrm{kPa} \\
\left(25^{\circ} \mathrm{F} \text { and } 100 \mathrm{psia}\right) \\
\end{array}$ & $\begin{array}{l}\text { Subcooled liquid } \\
\text { at } 272 \mathrm{~K} \text { and } \\
689.5 \mathrm{kPa}\left(30^{\circ} \mathrm{F}\right. \\
\text { and } 100 \mathrm{psia})\end{array}$ \\
\hline
\end{tabular}

\footnotetext{
$a_{\text {Ethane }}-0.605 \mathrm{~kg} / \mathrm{s}(80 \mathrm{1b} / \mathrm{min})$

Propene $-3.024 \mathrm{kgis}(400 \mathrm{lb} / \mathrm{min})$

Propane - $2.419 \mathrm{~kg}$ 's $(320 \mathrm{lb} / \mathrm{min})$

$b_{\text {Propene }}-0.756 \mathrm{kgis}(100 \mathrm{1b} / \mathrm{min})$

Propane - $0.756 \mathrm{kgis}(100 \mathrm{lb} / \mathrm{min})$
}

Note: In case 5 , the injected fluid is introduced into the piping system in the 5 -in. welding elbow. 


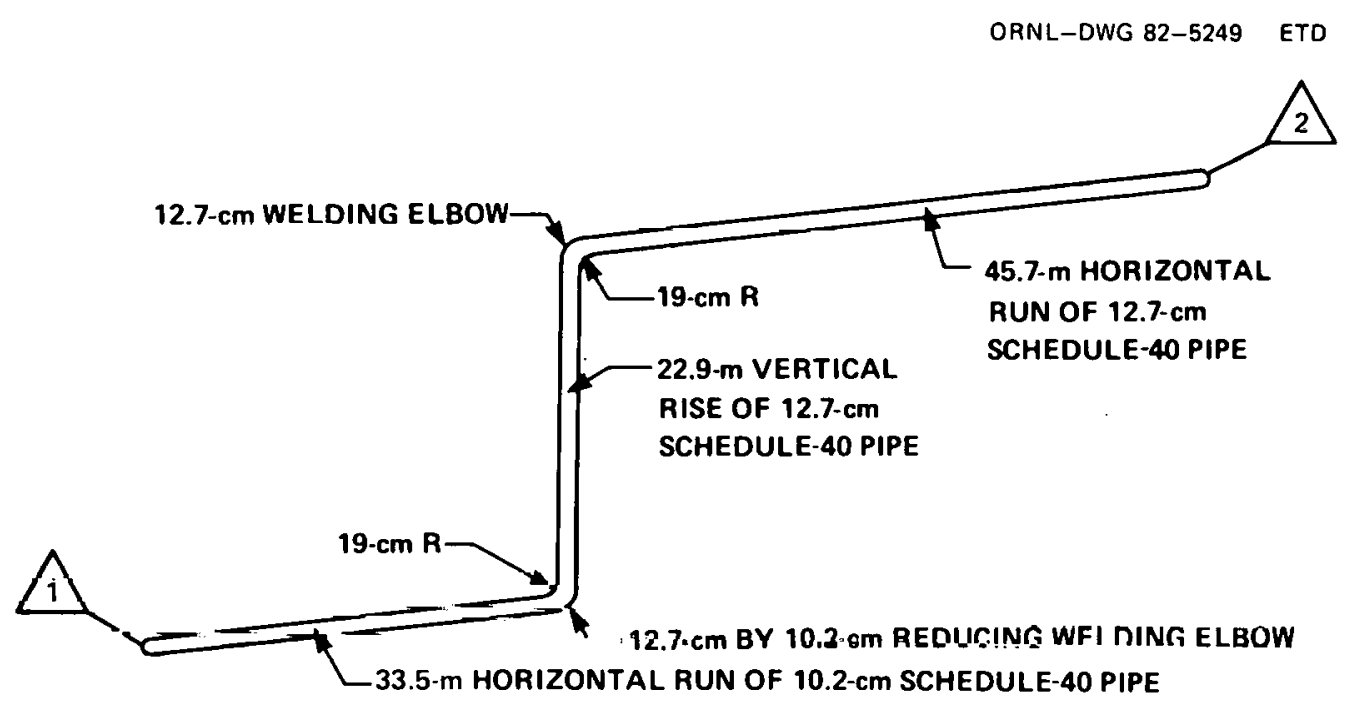

Fig. 15. Piping system. for sample problems.

piping system is shown in Fig. 16. The code input for cases 1-4 is exactly the same except for the primary feed stream temperature. Becanse there are 20 control volumes in the mode1, there would be 33 total pages of FFFAP output for each sample problem. For case 5 , the complete FFFAPVersion 1.0 output (a11 33 pages) will be given in Appendix B.7; however, for the remaining cases only pages 11 and 33 of the FFFAP output will be presented, because these pages contain the initial and final states of the fluid in the system.

In case 1 , the fluid is $\sim 12.8 \mathrm{~K}\left(23^{\circ} \mathrm{F}\right)$ subcooled initially and romains subcooled throughout the piping system. The initial and final states of the fluid (points 1 and 2 in Fig. 15, respectively) from the FFFAP output for this case are presented in Appendix B.3. In summary, a pressure drop of $128 \mathrm{kPa}(18.6 \mathrm{psi})$ and a temperature drop of $\sim 0.39 \mathrm{~K}$ $\left(0.7^{\circ} \mathrm{F}\right)$ occur between points 1 and 2 for case 1 .

In case 2 , the fluid is $\sim 3.6 \mathrm{~K}\left(6.5^{\circ} \mathrm{F}\right)$ superheated initially and, like the fluid in case 1 , remains single-phase through the system. The FFFAP results (pages 11 and 33) are given in Appendix B.4. For this case, there is an overall pressure drop of $242.7 \mathrm{kPa}(35.2 \mathrm{psi})$ and a temperature drop of $2.39 \mathrm{~K}\left(4.3^{\circ} \mathrm{F}\right)$.

At the initial conditions of $273.7 \mathrm{~K}\left(33^{\circ} \mathrm{F}\right)$ and $689.5 \mathrm{kPa}$ (100 psia), the fluid in case 3 is two-phase, and the weight fraction of the feed 


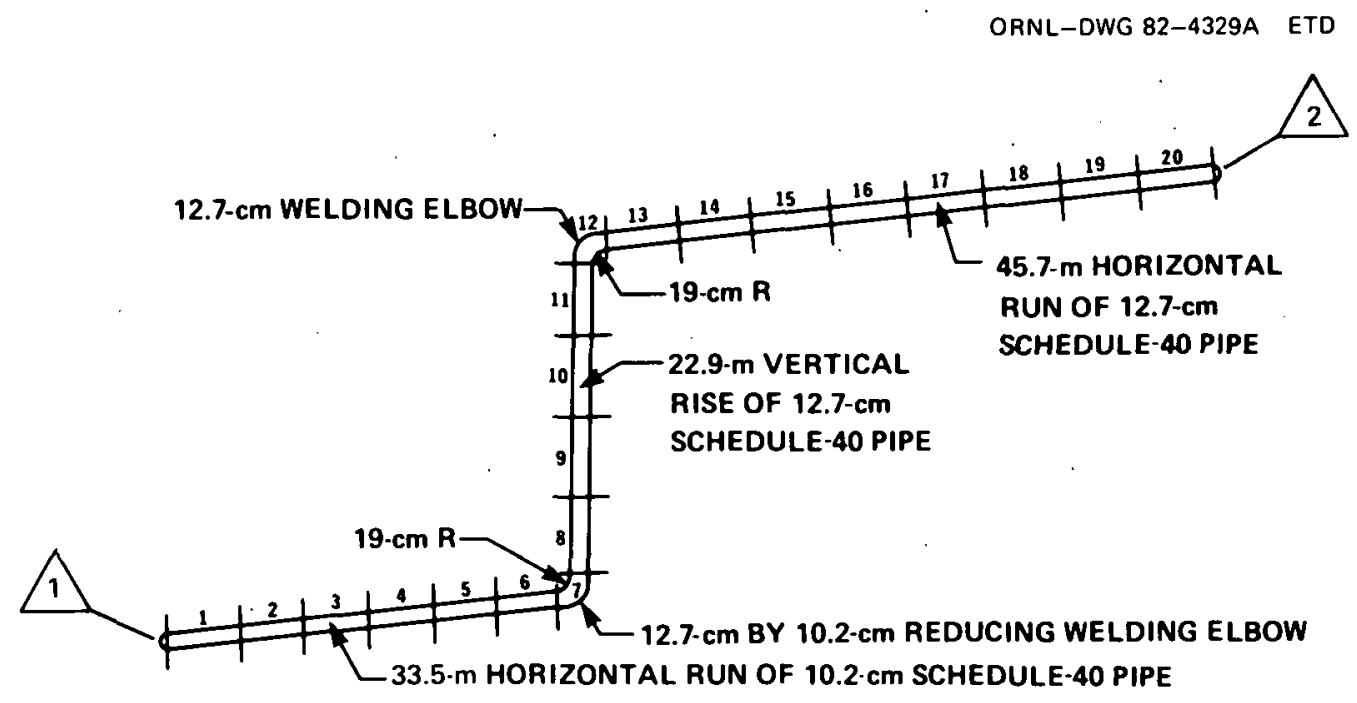
problems.

Fig. 16. Control volume representation of piping system for sample stream is vapor equal to 0.1628 . There is an overall pressure 1 oss of $155.8 \mathrm{kPa}(22.6 \mathrm{psi})$, a temperature drop of $8.1 \mathrm{~K}\left(14.6^{\circ} \mathrm{F}\right)$, and an increase in the fraction vaporized to 0.2064 . The FFFAP results (pages 11 and 33) are given in Appendix B.5.

In case 4 , the f1uid is $\sim 1.8 \mathrm{~K}\left(3.2^{\circ} \mathrm{F}\right)$ subcooled initially and remains subcooled until control volume 9 (Fig. 16), where the computed bubble-point temperature falls below the primary stream temperature and flashing occurs. Flashing initiates in node 9 and additional vaporization continues through node 20 . The initial and final states of the fluid for case 4 are presented in Appendix B.6. Overal1, there is a pressure drop of $\sim 107.6 \mathrm{kPa}(15.6 \mathrm{psi})$, a temperature drop of $3.1 \mathrm{~K}\left(5.6^{\circ} \mathrm{F}\right)$, and a weight fraction vaporized of 0.054 .

The initial set-up for case 5 is the same as for case 4. In fact, the calculational results are the same through control volume 11; however, an injected side stream is then introduced into control volume 12 , thus causing differences in case 4 and 5 caloulations downstream of control volume 12. The complete 33-page FFFAP output for this case is given in Appendix B.7.

Hopefu11y, the versatility, capability, and applicability of FFFAP have been demonstraled via thcse sample problems. 
In anticipation of reader comments about the sample problems, the following observations can be made:

1. the sample problem piping system is relatively simple (i.e.., no valves, orifices, etc.);

2. the sample problems are at a relatively low pressure;

3. even though it is a multicomponent system, the fluid is still relatively simple (i.e., compared with a coal liquefaction fluid).

These statements are al1 true, but what has been attempted in this phase of the work is to demonstrate the capability of FFFAP-Version 1,0. The iulent of the next phase of the work is to apply FFFAP (maybe with model improvoments) to more complex genmetries (i.e., valves and uxifices) and to model existing (or past) high-pressure coal liquefaction letdown systems (Chaps. 5 and 6 ).

\subsection{Code Verification}

Current1y, two approaches have been taken to verify the computations of FFFAP-Version 1.0. The first is the validation of the individual FFFAP modules. The second is the comparison of FFFAP results with alternative program results or hand calculations. However, no alternative oomputer programs do the same calculations as FFFAP.

As noted in Sect. 4.1 (code description), FFFAP consists of 36 modules, each of which is designed primarily for one function. This approach has allowed the validation of each individual module over the fu11 range of the input parameters to the module. In other words, when a module has been developed, it is rather simple to develop a driving routine to check the module over the full range of the module's required input paramoters and then compare the results with known data. For example, the FICFAC module (Table 3 ) that determines the Fanning friction factor, given a Reynolds number and a relative ronghness factor, was verified by deve1oping a routine that used FICFAC to dotermine the friclion factor for eight roughness factors over the Reynolds number range of 100-10\%: the results from this routine were then compared with existing data (Moody chart). A plot of the results from this routine is shown in Fig. 17 . 


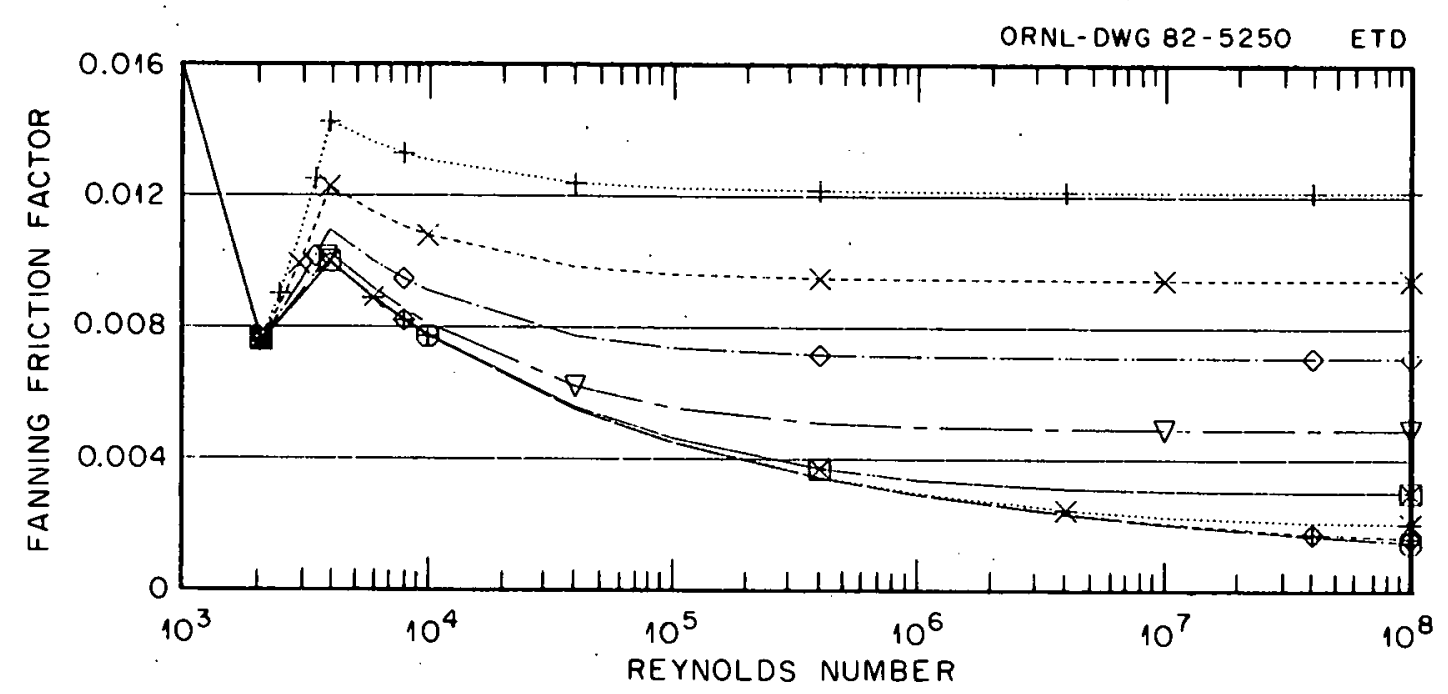

Fig. 17. Fanning friction factor as a function of Reynolds number and relative roughness.

Similarly, the horizontal slurry pressure-drop correlations were reviewed and a plot of those results is shown in Fig. 18. Each rontine (module) in FFFAP-Version 1.0 has been verified in this manner.

Even though each module may be verified as described previously, the integration of these individual routines into a large complex code such as FFFAP can create many additional problems. Once the large code (FFFAP) has been generated, it too must be verified. Ideally, this would be experimental verification (which hopefolly will be done in the future). Lacking experimental verification, the next best validation tool would be another code that can solve a similar problem - none exists. Therefore, the verification technique used for FPFAP-Version 1.0 is the classical hand calculation. "Hand calculation" is used rather loosely here because a great deal of hand calculator use is required. Calculational techniques as outlined in Crane ${ }^{39}$ will be used for compressible and noncompressible flow configurations.

Three FFFAP case results (for sample problems 1-3) given in Sect. 4.4 . and Appendix $B$ will be compared with the hand calculations. In case 1 , the fluid is subcooled $12.8 \mathrm{~K}\left(\sim 23^{\circ} \mathrm{F}\right)$ throughout the system, the temperature drop is $\sim 0.39 \mathrm{~K}\left(0.7^{\circ} \mathrm{F}\right)$, and the fluid density is approximately constant; therefore, the incompressible flow equations from Cranes should 


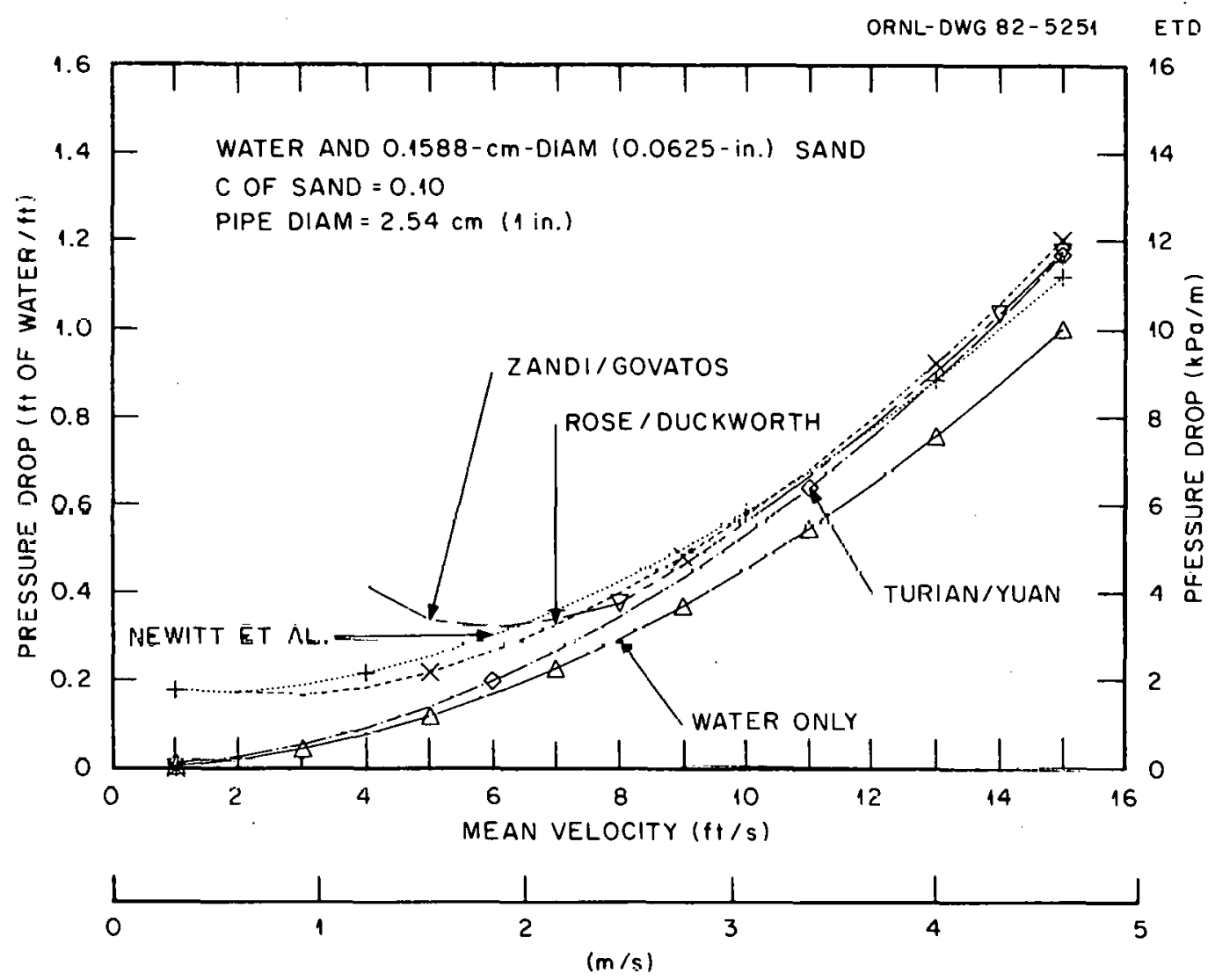
pipes.

Fig. 18. Pressure-drop correlations for slurry tlow in horizontal

give very similar resuits to FFFAP. A comparison of the results is shown in lable $\%$.

The fluid in case 2 is $\sim 3.6 \mathrm{~K}\left(6.5^{\circ} \mathrm{F}\right)$ superheated initially and remains one-phase throughout the system; however, the fluid temperature drops $2.39 \mathrm{~K}\left(4.3^{\circ} \mathrm{F}\right)$, the density decreases by $\sim 38 \%$, and the gas compressibility factor ranges from 0.88 to 0.93 . Among other assumptions, the compressible equation developed in Crane assumes (1) isothermal flow, and (2) that the gas obeys the perfect gas $1 \mathrm{aws}$. Therefore, the comparison should not be as close as for case 1; but the results should be reasonably similar. The results are compared in Table 8 .

In sample problem 3 , the fluid is two-phase throughout the system with the weight fraction vaporized ranging from 0.1628 to 0.2064 . Techniques suggested by Atherton and DeGance24 were used to perform the hand calculations. The results are compared in Table 9. 
Table 7. Comparison of pressure-drop calculations for sample problem 1

\begin{tabular}{lrr}
\hline & $\begin{array}{c}\text { Hand calculations } \\
{[\mathrm{kPa}(\mathrm{psi})]}\end{array}$ & \multicolumn{1}{c}{ FFFAP } \\
& $1 \mathrm{kPa}(\mathrm{psi})]$ \\
\hline Potential loss & $123.4(17.90)$ & $123.3(17.88)$ \\
Acceleration 1oss & $-0.3(-0.04)$ & $-0.3(-0.04)$ \\
Frictiona1 loss & $4.7(0.69)$ & $4.6(0.66)$ \\
Overa11 pressure drop & $127.8(18.55)$ & $127.6(18.50)$ \\
\hline
\end{tabular}

Tab1e 8. Comparison of pressure-drop calcnlations for sample problem 2

\begin{tabular}{lrr}
\hline & $\begin{array}{c}\text { Hand calculations } \\
{[\mathrm{kPa}(\mathrm{psi})]}\end{array}$ & $\begin{array}{c}\text { FFFAP } \\
{[\mathrm{kPa}(\mathrm{psi})]}\end{array}$ \\
\hline Potential loss & $2.3(0.34)$ & $2.2(0.32)$ \\
Acceleration loss & $3.2(0.46)$ & $1.0(0.14)$ \\
Frictional loss & $255.7(37.08)$ & $239.6(34.75)$ \\
Overa11 pressure drop & $261.2(37.88)$ & $242.8(35.21)$ \\
\hline
\end{tabular}

Table 9. Comparison of pressure-drop calculations for sample problem 3

\begin{tabular}{lrr}
\hline & $\begin{array}{c}\text { Hand calculations } \\
{[\mathrm{kPa}(\mathrm{psi})]}\end{array}$ & \multicolumn{1}{c}{ FFFAP } \\
& $72.4(10.50)$ & $72.3(10.49)$ \\
\hline Potential loss & $0.7(0.10)$ & $0.5(0.07)$ \\
Acceleration loss & $103.8(15.06)$ & $82.9(12.02)$ \\
Frictional loss & $176.9(25.66)$ & $155.7(22.58)$ \\
Overall pressure drop & & \\
\hline
\end{tabular}


In reviewing the comparisons, the following points should be considered:

1. In the hand calculations, the system (Fig. 15) was broken down into two horizontal runs and one vertical run; mean properties and flows were used in the computations. The results from each section were combined into the loss terms shown in the tables.

2. FFFAP used more control volumes (20) to represent the system and an iterative technique that included changes in physical properties and weight fraction vaporized for pressure convergence (from junction face to node center and from node center to junction face).

Thus, the hand calculations must be considered coarser than the FFFAP computations; even so, the comparisons are reasonably close enough to give credence to the results generated by FFFAP. Ultimate verification of FFFAP will have to be done experimental1y. 


\section{FUTURE MODEL IMPROVEMENTS}

As noted previously, FFFAP-Version 1.0 is a preliminary version of the engineering model and the code. Primarily because of time constraints, some desired features (such as the nonadiabatic and nonNewtonian capabilities) have not been verified and included in the model and the code. Future efforts will include removing many of the 1 imitations and assumptions (Sect. 3.3) imposed on the engineering model and this release of FFFAP.

FFFAP-Version 1.0 is currently limited to Newtonian fluids. Implications are made in Tables 1 and 4 that efforts are under way to remove this restriction. For instance, the purposes of one of the control parameters (No. 11, Table 4) is to signal the internal code logic that the user has supplied a module that will compute the apparent liquid viscosity. This module (to be coded by the user) could describe a power-law flnid, a Binghám plastic, or a model of the user's choice; it could be a function of shear rate, temperature, and pressure. For the criteria of turbulence for power-1aw slurries, the approach by Metzner and Reedto will be used; to account for the settling nature of the slurry, a correlation by Harris and Quader 1 may be used.

The next major restriction in FFFAP-Version 1.0 is that the process is adiabatic. The framework exists within the current version of FFFAP to solve the nonadiabatic problem within a control volume. What is lacking is the capability to compute a heat transfer coefficient at the control volume inner wall. Not only are heat transfer correlations required but also correlations for fluid heat capacity and thermal conductivity. Neither the heat transfer nor the physical property correlations exist in FFFAP-Version 1.0; they would need to be added.

Most of the physical property correlations that are in FFFAP are based on corresponding states theory. If experimental data were available, preferably, the user would supply the code with that data. Provisions will be made to allow the user to specify experimentally available liquid density, viscosity, liquid/gas interfacial surface tension, and vaporization equitibititi ratios via nser-supplied FFFAP modules. 
Currently, the user has a fair degree of flexibility in the hydrodynamic relationships (Table 2) that are employed in a problem to be solved by FFFAP. However, the user is not given much choice in the physical property and thermodynamic relationships (Table 1) that are nsed. More user flexibility is needed in this area, and proposed correlations for addition to FFFAP are 1 isted in Table 1.

The points made in the preceding four paragraphs will probably be given first priority in future efforts, but the following are additiona 1 concerns (assumptions) that should be reviewed when the time and funds become available:

1. the assumption that the fluid is homogeneous (i.e., no s1ip), and 2. the assumption that the gas and liquid streams are in thermodynamic equilibrium.

The model and code are presently one-dimensional. If the effects of solids erosion in coal 1 iquefaction letdown valves are given due study, then it would be preferable to know (at least) the two-dimensional flow fields (patterns) in the valve. So far, a simplified particle trajectory approach has been taken, but this area (i.e., particle erosion) needs more study and possibly a more rigorous engineering model.

On the subject of future model improvements, current recommendations cannot be made to the user about FFFAp modeling techniques or the use of a specific physical property, thermodynamic, or hydrodynamic relationships. These suggestions can only come from attempts to mode1 an experimental flow system. Given an experimental apparatus, the code conld be verified, different modeling techniques could be tried, and the physical property, thermodynamic, and hydrodynamic relationships could be studied. Then, positive recommendations conld be made to the user on modeling methods and preferred correlations. 


\section{CONCLUSIONS AND RECOMMENDATIONS}

A preliminary engineering model and computer code (FFFAP-Version 1.0) have been developed for use in the analysis of multicomponent, multiphase, flashing, flowing systems. This model and code were developed with intended application to coal liquefaction high-pressure letdown systems. The code is highly generalized; although it was designed for the analysis of coal liquefaction letdown systems, it can be applied to any piping system with any fluid constituents.

A general description of the model, its 1 imitations, and the physical property, thermodynamic, and fluid-dynamic relationships employed in the model are presented. A fairly detailed description of the preliminary computer code is given, and the applicability of the code is illustrated by five sample problems that range from.single-phase flow to flashing multicomponent flow with injected side streams.

These are preliminary versions of the model and the code; because of time constraints, some desired features (such as nonadiabatic, nonNewtonian capabilities) have not been verified and included in this version of the code. Future model improvements (such as the inclusion of the nonadiabatic, non-Newtonian capabilities) are suggested. Also, the point is made that verifying the code and testing various modeling techniques, can best be done with an experimental system.

The next phase of the work should be to apply the code (maybe with model improvements) to more complex geometries (valves and orifices) and to model existing (and past) high-pressure coal liquefaction letdown systems. 


\section{REFERENCES}

1. J. F. Gardnex, Program Rationale Valves for Solids Throttling Applications in Coal Conversion and Utilization Processes, METC/CR-79/14 (August 1979).

2. D. W. Hatcher et a1.. Survey of Industrial Coal Conversion Equipment Capabilities: Letdown Valves, ORNL/TM-6585 (November 1979).

3. DOE/ICRC Letter No. 1055, "Letdown Valve Sizing Data Acquisition Program at H-Coa1," from Y. K. Bhide of ICRC, Allentown, Penn., to Michael Eastman, U.S. Department of Energy, Oak Ridge, Tenn. (September 1981).

4. T, L. Dah1, "Coal Liquefucliul Letdown Valvo Oporating Experience at. Coal Liquefaction Pilot Plants," paper presented at the Fourth Annual SCIEP-DOE Seminar/Workshop on Instrumentation and Control for Fossil Energy Processes, Clearwater Beach, Florida (Feb, 1, 1982).

5. R. C. Reid, J. M. Pransnitz, and T. K. Sherwood, The Properties of Gases and Liquids, McGraw-Hill Book Company, New York, 1977.

6. E. J. Henley and J. D. Seader, Equilibrium-Stage Separation Operations in Chemical Engineering, John Wiley, New York, 1981.

7. L. C. Yen and R. E. Alexander, "Estimation of Vapor and Liquid Enthalpies," AIChE Journal 11(2), 334-39 (March 1965).

8. Byung-Ik Lee, J. E. Erbar, and W. C. Edmister, "Prediction of Thermodynamic Properties for Low Temperature Hydrucarbon Process Caloula= tions," AIChE Journal 19(2), 349-56 (March 1973).

9. P. L. Chueh and J. M. Prausnitz, "Vapor-Liquid Equilibria at High Pressures: Calculations of Partial Molar Volumes in Nonpolar Liquid Mixtures," AIChE Journal 13(6), 1099-1107 (November 1967).

10. P. L. Chueh and J. M. Prausnitz, "A Generalized Currelation for thc Compressibilities of Normal Liquids," AIChE Journal 15(3), 471-72 (May 1969).

11. L. C. Yeh and S. S. Woods, "A Generalized Equation for Computer Ca1culation of Liquid Densities," AIChE Journal 12(1), 95-99 (January 1966).

12. J. H. Hildebrand and R. L. Scott; Regutar Solutions, Prentice-Ha11, Englewood C1 iffs, N.J., 1962.

13. H. G. Grayson and C. W. Streed, "Vapor-Liquid Equilibria for HighTemperature, High-Pressure Hydrogen-Hydrocarbon Systems," Sirth World Petroleum Conference (Paper 20-PD7), Frankfurt, Germany (June 1963). 
14. M. S. Graboski and T. E. Daubert, "A Modified Soave Equation of State for Phase Equilibrium Calculations. 1. Hydrocarbon Systems," Ind. Eng. Chem. Process Des. Dev. 17(4), 443-48 (1978).

15. M. S. Graboski and T. E. Daubert, "A Modified Soave Equation of State for Phase Equilibrium Calculations. 2. Systems Containing $\mathrm{CO}_{2}, \mathrm{H}_{2} \mathrm{~S}$, $\mathrm{N}_{2}$ and C0," Ind. Eng. Chem. Process Des. Dev. 17(4), 448-54 (1978).

16. M. S. Graboski and T. E. Daubert, "A Modified Soave Equation of State for Phase Equilibrium Calculations. 3. Systems Containing Hydrogen," Ind. Eng. Chem. Process Des. Dev. 18(2), 300-306 (1979).

17. A. Letsou and L. I. Stiel, "Viscosity of Saturated Nonpolar Liquids at El evated Pressures," AIChE Journal 19(2), 409-11 (March 1973).

18. D. E. Dean and L. I. Stiel, "The Viscosity of Nonpolar Gas Mixtures at Moderate and High Pressures," AIChE Journal 11(3), 526-32 (May 1965).

19. K. C. Chao and J. D. Seader, "A General Correlation of Vapor-Liquid Equilibria in Hydrocarbon Mixtures," AIChE Journal 7(4), 598-605 (December 1961).

20. G. W. Govier and $\mathrm{K}$. Aziz, The Flow of Complex Mixtures in Pipes, VanNostrand Reinhold Company, New York, 1972.

21. L. F. Moody, "Friction Factors for Pipe F1 ow," Trans. ASME 66, 671-84 (1944).

22. R. W. Lockhart and R. C. Martine11i, "Proposed Correlation of Data for Isothermal Two-Phase, Two-Component Fl ow in Pipes," Chemical Engineering Progress 45(1), 39-48 (January 1949).

23. A. E. Dukler, M. Wicks, and R. G. C1eveland, "Frictional Pressure Drop in Two-Phase F1 ow: A. A Comparison of Existing Correlations for Pressure Loss and Holdup," $A \bar{I} C h \bar{E}$ Journal 10(1), 38-43 (January 1964).

24. A. E. DeGance and R. W. Athertor, "Chemical Engineering Aspects of Two-Phase Flow," Reprint from Chem. Eng., McGraw-Hil1, 1970-71.

25. A. E. Dukler, "Gas-Liquid Fl ow in Pipelines. 1. Research Results," Monograph prepared on Project NX-28 at the University of Houston for the American Gas Association. Inc., and the American Petroleum Institute, May 1969.

26. Y. Taite1, D. Bornea, and A, E, Duk1er, "Mode11ing F1 ow Pattern Transitions for Steady Upward Gas-Liquid Flow in Vertical Tubes," AIChE Journal 26(3), 345-54 (May 1980). 
27. J. M. Mandhane, G. A. Gregory, and K. Aziz, "A Flow Pattern Map for Gas-Liquid F1ow in Horizontal Pipes," Int. J. Multiphase Flow 1. 537,553 (1974).

28. J. M. Mandhane, G. A. Gregory, and K. Aziz, "Critical Evaluation of Friction Pressure-Drop Prediction Methods for Gas-Liquid Flow in Horizontal Pipes," J. Pet. Technol., 1348-58 (October 1977).

29. G. A. Gregory, "Comments on the Prediction of Liquid Holdup for GasLiquid Flow in Inclined Pipes," Can. J. Chem. Eng. 52, 463-67 (August 1974).

30. G. A. Gregory, "Comparison of Methods for the Prediction of Liquid Holdup for Upward Gas-Liquid Flow in Inc1ined Pipes." Can. J. Chem. Eng. 53, 384-88 (Angust 1975).

31. J. M. Mandhane, G. A, Gregory, and K. Aziz, "rritical Evaluation of Holdup Prediction Methods for Gas-Liquid Flow in Horizontal Pipes," J. Pet. Technol., 1017-1026 (August 1975).

32. R. M. Turian and Tran-Fu Yuan, "Flow of S1urries in Pipelines," AIChE Journal 23(3), 232-43 (May 1977).

33. D. M. Newitt, J. F. Richardson, and B. J. Gliddon, "Hydraulic Conveying of Solids in Vertical Pipes," Trans. Instn. Chem. Engrs. 39, 93100 (1961).

34. H. E. Rose and R. A. Duckworth, "Transport of Solid Particles in Liquids and Gases," The Engineer 227(5903), 392 (1969); 227(5904), 430 (1969); 227(5905), 478 (1969).

35. D. M. Newitt, J. F. Richardson, M. Abbott, and R. B. Turt1e, "Hydrau1 ic Conveying of Solids in Horizontal Pipes," Trans. Instn. Chem. Enyy'd. 93, 93-106 (1955).

36. J. Orkiszewski, "Predicting Two-Phase Pressure Drops in Vertical Pipe," J. Pet. Technol., 829-38 (Ju1y 1967).

37. A. E. Dukler, M. Wicks, and R. G. C1eveland, "Frictional Pressure Drop in Two-Phase Flow: B. An Approach Through Similarity Analysis," AIChE Journal 10(1), 44-51 (January 1964).

38. G. A. Hughmark, "Holdap in Gas-Liquid F1ow," Chem. Eng. Prog. 58(4), 62-65 (Apri1 1962).

39. Crane Company, "Flow of Fluids Through Valves, Fittings, and Pipe," Technical Paper No. 410 (1976).

40. A. B. Metzner and J. C. Reed, "Flow of Non-Newtonian Fluids - Correlation of the Laminar. Transition and Turbulent Flow Regions," AIChE Journal 1(4), 434-40 (December 1955). 
41. J. Harris and A. Quader, "Design Procedures for Pipelines Transporting Non-Newtonian Fluids and Solid-Liquid Systems," Br. Chem. Eng. 16(4/5), 307-11 (April/May 1971). 
56

\section{THIS PAGE}

\section{WAS INTENTIONALLY \\ LEFT BLANK}




\section{Appendix A}

DETAIED CODE INPUT DESCRIPTION

This appendix could be used as an abbreviated user input guide to FFFAP; however, it is intended to illustrate instead the structure of the code input in more detail than was given in Sect. 4.2. The primary information blocks and the required order in the user-generated input are shown in Fig. A.1. As noted in Sect. 4.3, the INPUT module in FFFAP checks the order of the input stream (that is, it checks for the required sequence of the card images): if it finds card images out of sequence, the code will terminate the job at that point. Each card image uses the first ten columns for identification information: the first four columns are alphanumeric and are primarily used to identify libraries (the blocks in Fig. A.1); the next six columns contain a six-digit sequential identifier that INPUT uses to check the order. An example of a code input deck is given in Appendix B.2.

The card image construction for the FFFAP user-defined input stream is illustrated on pages 60 and 61 . At the top of each page (below the heading) is a line showing the 80-column field width of a card image. The

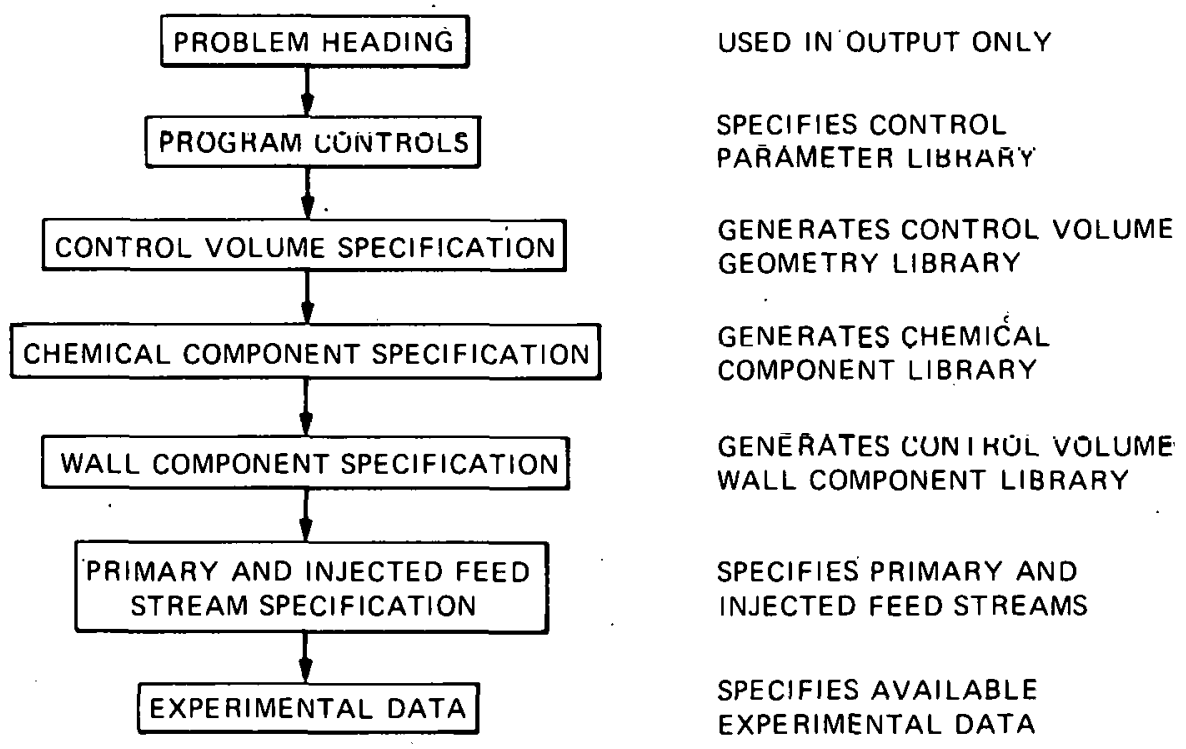

Fig. A.1. Outline of FFFAP nser input requirements. 
remainder of each page (60 and 61 ) contains the card images required and the input variables required for each card. The blocks in the outline in Fig. A.1 can be identified on pages 60 and 61 by the three letters beginning each card and by Table A.1.

Table A.1. FFFAP input blocks and card identifiers

\begin{tabular}{|c|c|}
\hline B1ock ${ }^{\alpha}$ & Card idontifier $b$ \\
\hline $\begin{array}{l}\text { Problem hoading } \\
\text { Program controls } \\
\text { Control volume specification } \\
\text { Chemioal component specification } \\
\text { Wall component specification } \\
\text { Primary feed specification } \\
\text { Injected feed specification } \\
\text { Experimental data }\end{array}$ & $\begin{array}{l}\text { HDR } \\
\text { CTT. } \\
\text { NOD } \\
\text { GHE } \\
\text { WAL } \\
\text { FED } \\
\text { IFD } \\
\text { DAT }\end{array}$ \\
\hline
\end{tabular}

The variable definitions (dcscriptions) fur the control volume speoification block (cards 100000-1XXX1J) are given on pages 62 and 63 . Line 100000 apyears only once and initiates the user-defined control volume information section. Line 100001 appears only once and defines the number of control volume modules ( 1 ines $1 \times \times \times 00-1 \times \times \times 1 J$ ) to be read (i.e., it is the total number of control volumes used by the user to model a flow system). Lines $1 \times X X 00-1 \times X X 03$ are required for each control volume and 1 ines $1 X X X 04$ and $1 X X X 10-1 X X X 1 J$ are optional for each control volume (inoludod only if KADBTC is nonzero).

The chemical library variable definitions (cards 200000-20XX07) are given on page 64 . Line 200000 appears only once and initiates the user chemical library section of the input. Line 200001 appears only once and defines the number of chemical compound modules (1ines 20xx00-20xx07) to be read. See page 68 for other pertinent notes on the chemical 1 ibrary input. 
The wall component 1 ibrary variable definitions (cards 250000-25YY01) are given on page 65 . Lines 250000 and 250001 appear only once. These lines initiate the user wall component 1 ibrary input section and define the number of wall material modules (1ines $25 Y Y 00$ and $25 Y Y 01$ ) to be read.

The primary and injected feed stream variable definitions (cards 300000-30000J and 350000-35ZZOJ) are given on page 66. Line 300000 appears once and initiates the user-defined feed stream specification section. Line 300001 appears once and defines the number of chemical compounds in the feed stream and specifies the feed stream temperature and pressure. Lines 300002-3000JJ fully define the feed stream composition by specifying the components in the stream and their mass flow rates: Line 350000 appears only once and initiates the user-defined injected feed stream specification section. Line 350001 appears only once and defines the number of injection feed stream modules ( 1 ines $35 Z Z 00-35 Z Z J)$ to be read.

The experimental data variable definitions (cards 400000-4001JJ) are given on page 67 . Line 400000 appears only once and initiates the user-defined experimental data specification section. Line 400100 appears only once and defines the number of experimental data sets ( 1 ines 400101-4001JJ) to be read.

A summary of pertinent notes related to the user-defined input stream is given on page 68 .

Line 999999 appears only once and defines the last 1 ine of user input. 
$\begin{array}{ccc}\star \star \star & \text { THE FLASHING FLUID FLOW ANALYSIS PROGRAM-VERSION } 1.0 \\ \star \star \star & \text { THE LINETFIELD COLUMN CONSTRUCTION } & \star \star *\end{array}$

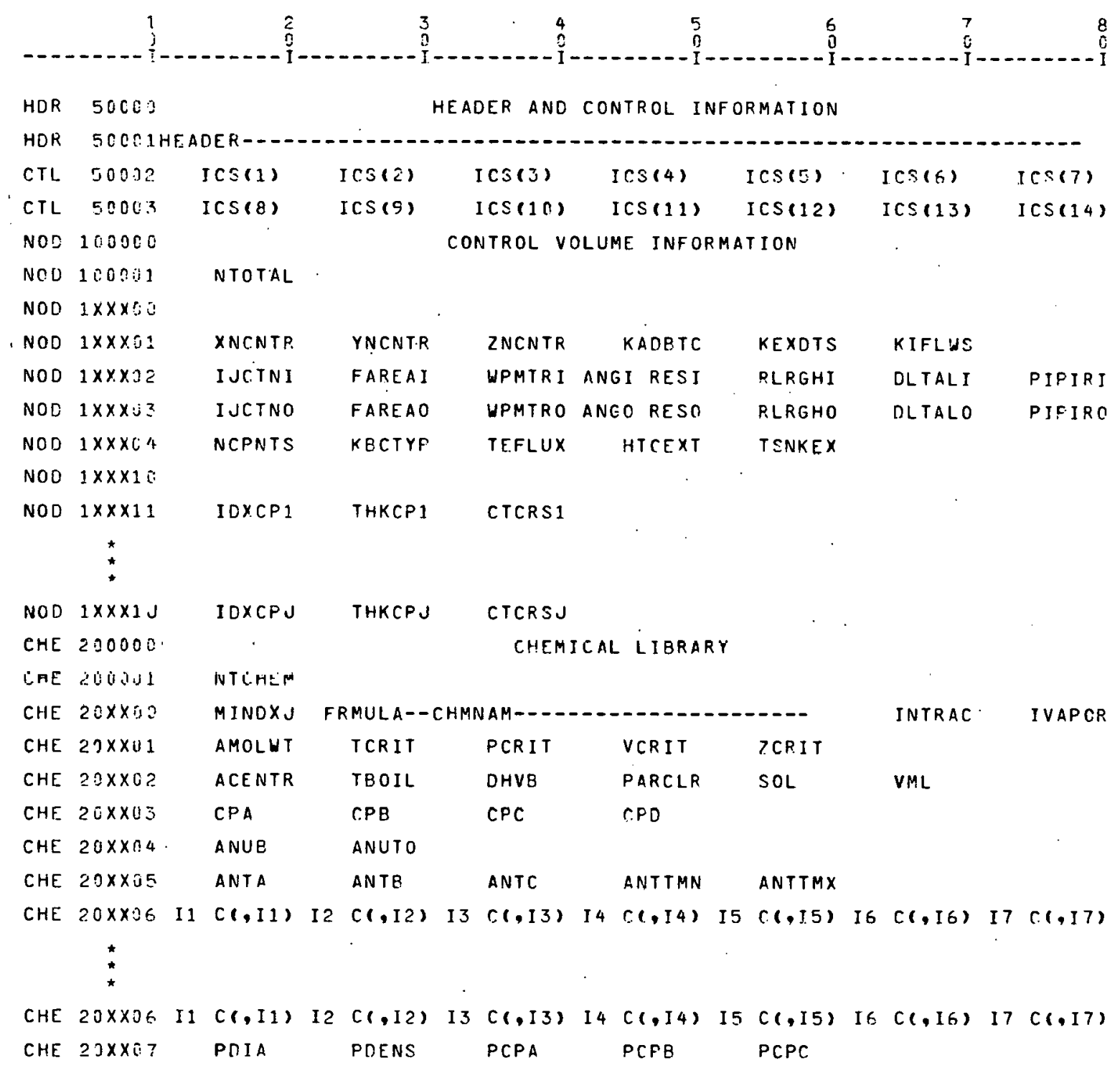



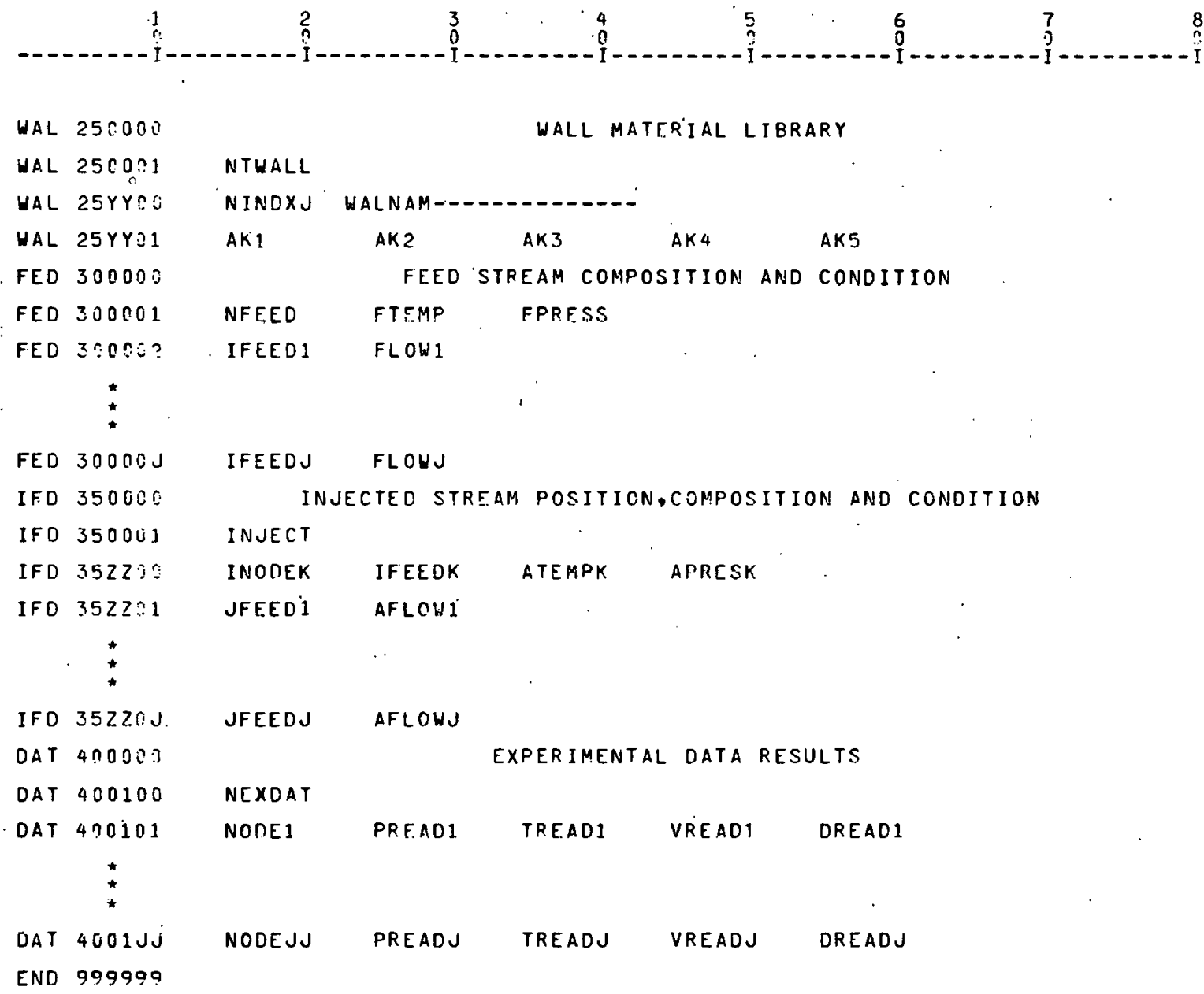
\#** THE. FLASHING FLUID FLOW ANALYSIS PROGRAM-VERSION 1 . *** CONTROL VOLUME INFORMATIUN SECTIUN

* * THE REQUiRed CONTROL VOLIIME VARTAPI.E DESTRTFTIONS

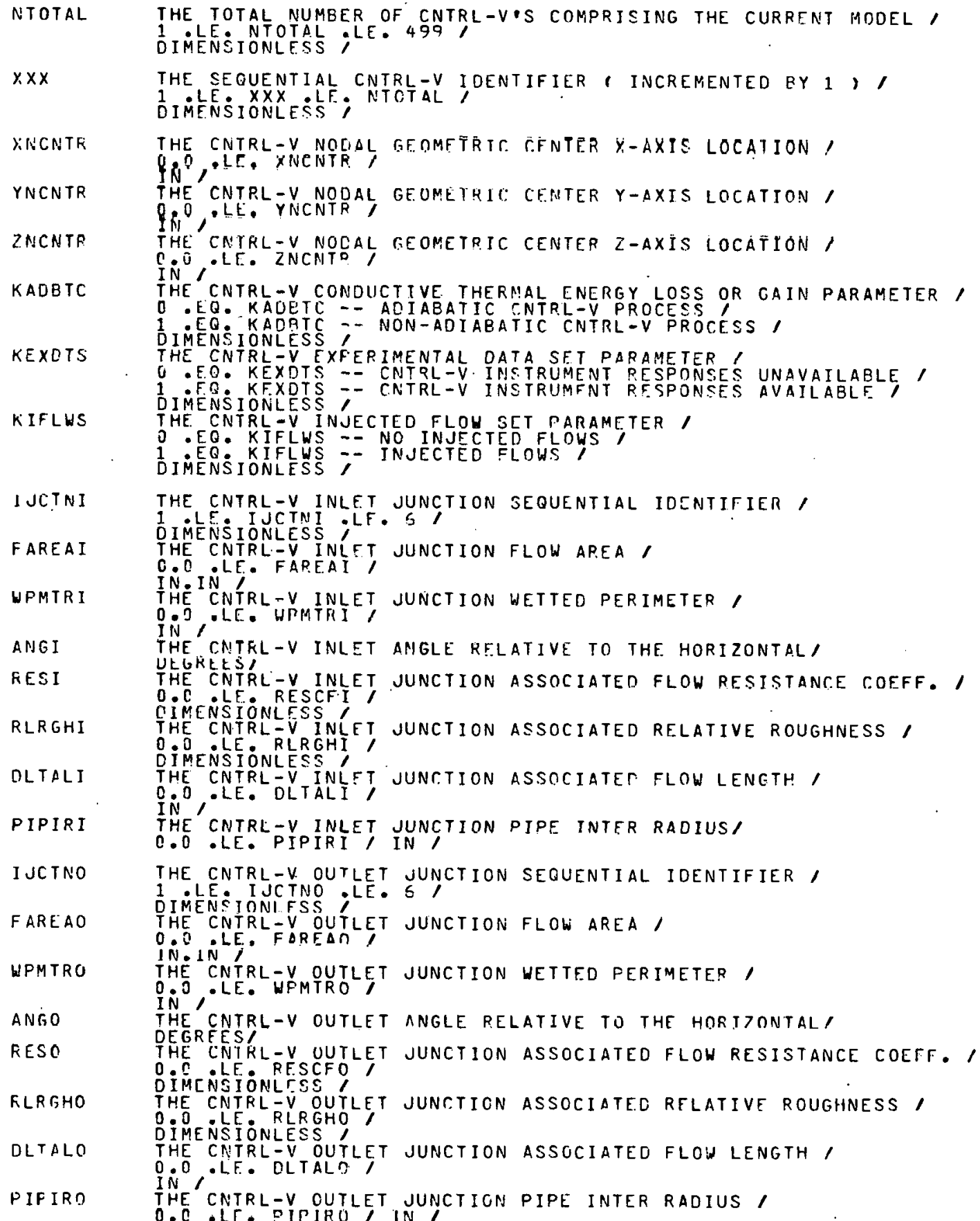


* * THE FLASHING FLUIO FLOW ANALYSIS PROGRAM-VERSION 1.0

*** $*$ CONTROL VR-DEFINED INPUT STREAM

***
** *HE OPTIONAL CONTROL VOLUME VARIARLE DESCRIPTIONS

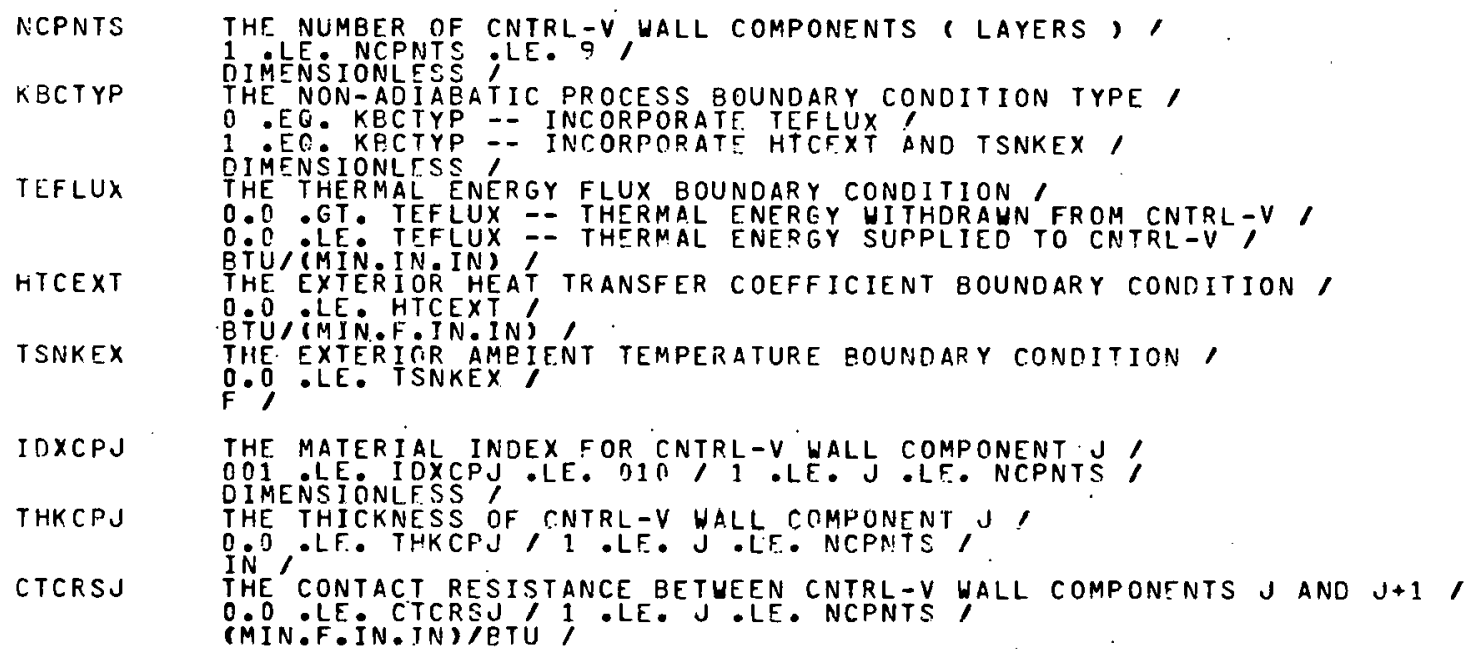

CTCRSJ 


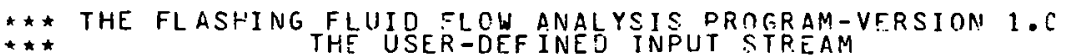
CHE MICAL LIBRARY INFO?MATION SECTION

THE CHEMICAL LIPRARY VAFIABLF DESCRIFTIONS

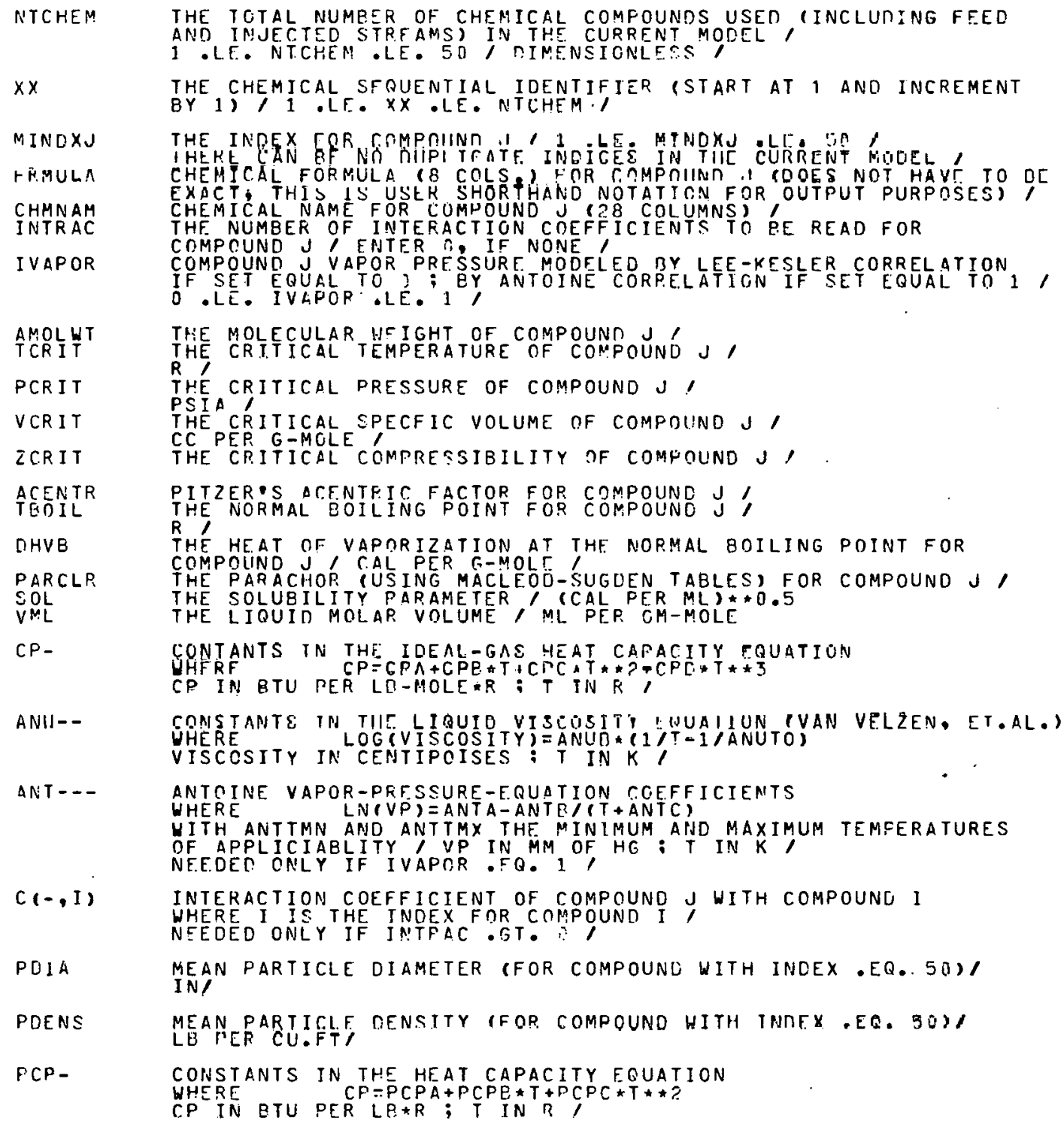

PDENS

PCPIN

MEAN PARTICLF, DENSITY IFOR COMPOUND HITH THNEX. EQ. 503

CONSTANTS IN THE HEAT CAPACITY EQUATION

WPERE IN BTU PER LP*R; T IN R 
* * THE FLASHING FLUIDFLOW ANALYSIS PROGRAM-VERSION 1.3
$\star \star *$ \#\# THE MATERTAL LIBRARY INFORMATION SECTION
** THE LIBRARY VAKIABLT DESCKIPIIONS

NTWALL THE TOTAL NUMBER OF MATERIALS USED IN THE CONTROL VOLUME

YY WALL CONSTRUCTION / 1 . LE. MTWALL.LE. I THE MATERIAL SEQUENTIAL IDENTIFIER (START AT 1 AND INCREMENT

NINDXJ

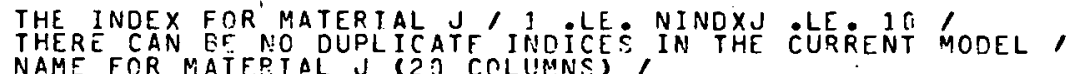

WALNAN CONSTANTS IN THE. THERMAL CONDUCTIVITY EQUATION FOR MATERIAL J WHERE INT PTU PER TN*MIN*R;TTINRI, TN

$A K$ - 


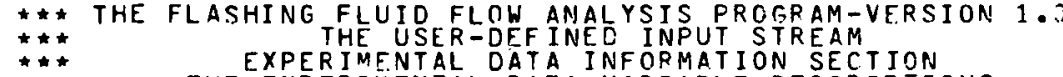
THE. EXPERIMENTAL DATA VARTABLE. TESCRIPTIONS

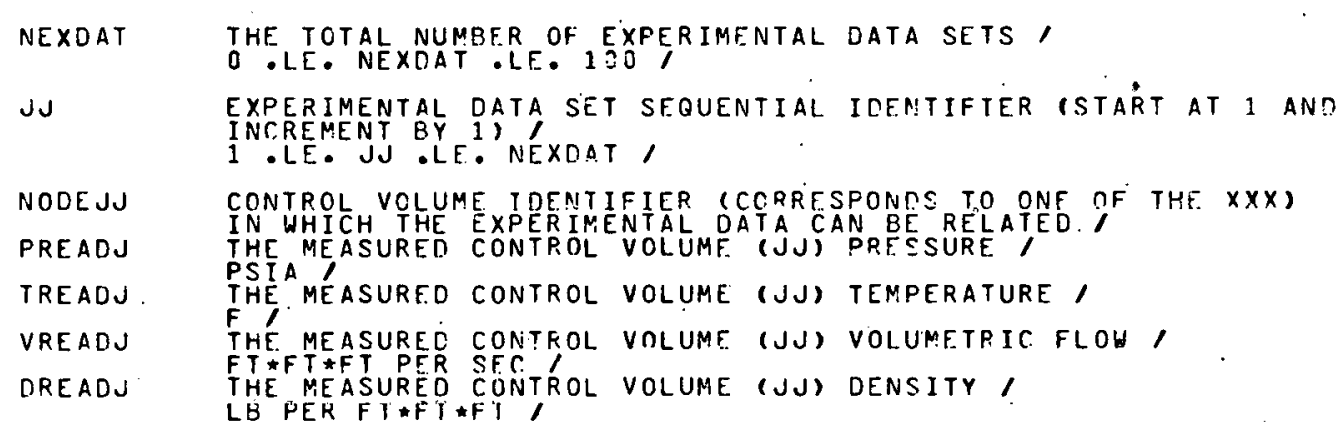




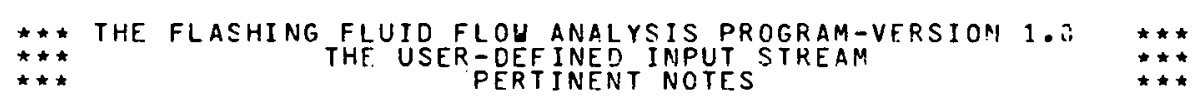

\# LIMI 1 POOOO APFEARS ONLY ONCE AND INITIATES THE USER-DEFINED INPUT STREAM CNTEL - V INFORMATION SECTION

\# LINE 1 TCOOI APPEARS ONLY ONCE AND DEFINES THE NUMBER OF CNTRL-V VARIABLE.

LINES $1 \times X \times 0 O$ THROUGH $1 \times X \times 03$ ARE REQUIRED FOR EACH CNTRL-V " LINES $1 \times X X O 4$ AND $1 \times X X X O$ THROUGH $1 \times X X 1 \mathrm{I}$ ARE OPTIONAL FOR EACH CNTRL-V AND

\# LINE 200000 APPEARS ONLY ONCE AND INITIATES THE USER-DEFINED INPUT STREAM CHEMICAL LIBRARY INFORMATION SECTION

+ LINE 230001 APPEARS ONLY ONCE ANO DEFINES THE NUMBER OF CHEMICAL COMPOUNC MODULES (LINES $20 X X 0 \mathrm{C}$ THROUGH $29 \times X O E$ ) TO BE READ

\# LINTS $20 X X O O$ THROUGH $20 X X O 4$ ARE REGUIRED FOR EACH CHEMICAL COMPOUNO (EXCEPT FOR XX.EQ.5G, THEN ONLY LINES 2 SXXOO AND $29 \times \times 07$ ARE NEEDED)

\# LINE $20 \times \times 95$ IS OPTIONAL FOR EACH CHEMICAL COMPOUND AND IS INCLUOED ONLY IF IVAPOR IS EQUAL TO 1

\# LINE(S) $23 \times X 06$ IS OPYIONAL FOR EACH CHEMICAL COMPOUND AND IS (ARE) INCLUDED ONLY IF INTRAC IS NONZERO. LINE $20 X X O 6$ CAN BE REPEATED AS MANY TIMES FOR EACH COMPOUND AS NECESSARY TO INPUT INTRAC VALUES OF THE INTERACTION COEFFICIENT ( 7 PER LINE).

\# LINF $20 X X E 7$ IS TO BE USED ONLY HHEN XX.EQ.55 [THAT IS, XX.EQ.5? IS

\# LINE $2500 G 0$ APPEARS ONLY ONCE AND INITIATES THF USER-DEFINED INPUT STREAM WALL MATERIAL LIBRARY SECTION.

\# LINF 250001 APPEARS ONLY ONCE AND DEFINES THE NUMBER OF WALL MATERIAL MODULES (LINES 25YYOC AND $25 Y Y D 1$ ) TO BE R.EAD.

\# LINES $25 Y Y 30$ AND $25 Y Y O 1$ ARE REQUIRED FOR EACH WALL MATERIAL.

\# LINE $3000 O 9$ APPEARS ONLY ONCE ANO INITIATES THE USER-DEFINED INPUT STREAM FEED STREAM SFECIFICATION SECTION.

$\#$ LINE 300001 APPEARS ONLY ONCE AND DEFINES THE NUMBER OF CHEMICAL COMPOUNDS IN THE FEED STREAM AND SPECIFIES THE FEEO STREAM TEMPERATURE ANU PRESSURE.

\# LINES 300002 THROUGH $30000 J$ FULLY DEFINE THF FEED STREAM COMPOSITION RY SPECIFYING THE COMPONENTS IN THE STREAM AND THEIR MASS FLOW RATES.

\# LINIS 350000 APPEARS ONLY ONCE AND INITIATES THE USER-DEFINED INPUT STREAN. INJECTICN FEED STREAM SPECIFICATION SECTION.

\# LINE $3500 C 1$ APPEARS ONLY UNCE AND DEFINES IHE. NUMBER OF 1 NJECIION FELU STR.F.AM MODULES (LINES $352 Z$ IC THROUGH $352 Z$ ПJ) TO BE READ.

\# LIPES 352200 THROUGH $352.20 \mathrm{~J}$ ARF REQUIRED FOR EACH INJECTION FEED

\# LINE 400000 APPEARS ONLY ONCE AND INITIATES THE USER-DEFINED INPUT STREAM EXPER IMENTAL DATA SPECIFICATION SECTION.

\# LINE 4 QOIOO APPEARS ONLY ONCE AND DLFINFS THF NUMBER OF EXPERIMENTAL DATA SETS (LINES $4001 C 1$ THROUEH 4DSIJU) TO BE READ.

\# LINE 999909 APPEARS ONLY ONCE ANE OEFINES THE LAST LINE OF USER INPUT. 


\section{Append ix $B$}

\section{SAMPLE PROBLEMS}

\section{B.1 Problem Definition and Description}

Five sample problems will be presented to demonstrate the versati1ity, capability, and applicability of FFFAP-Version 1.0.

The piping system to be studied is relatively simple (a schematic of the system is shown in Fig. B.1). Flow in the system is from point 1 to point 2 in Fig. B:1, and the fluid is a mixture of ethane, propene, and propane. The five case descriptions are given in Table B.1. The initial boundary conditions for the fluid at point 1 (Fig. B.1) are known and are given in Table B.1. The only difference between cases 1-4 is the initial temperature of the fluid. Case 5 contains an additional twist: the initial conditions at point 1 are the same as for case 4 , but a side stream has been introduced into the upper elbow in the piping system. The primary objective in these sample problems will be to determine the overall pressure drop between points 1 and 2 (Fig. B.1) and to determine the final state of the fluid at point 2 .

In these sample problems, 20 control volumes (nodes) are used to represent the piping system (Fig. B.1). The noding representation of

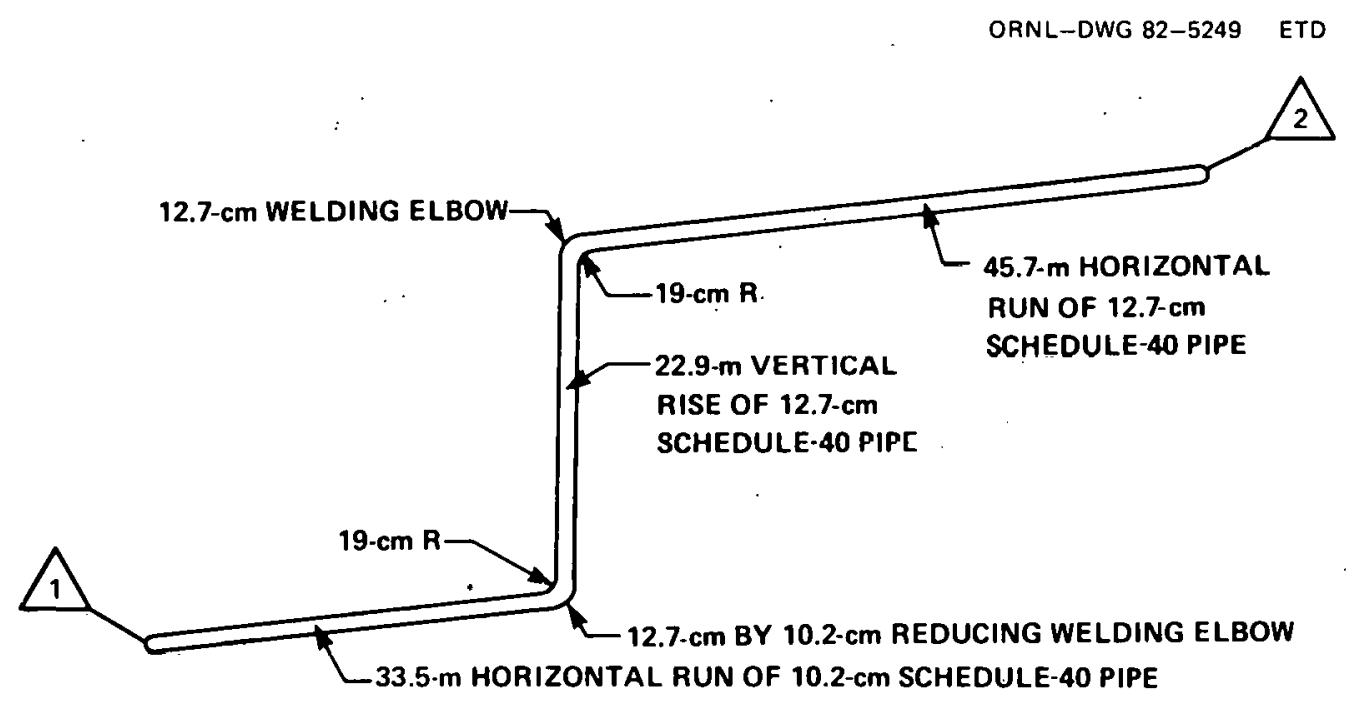

Fig. B.1. Piping system for sample problems. 
Table B.1. Sample p=oblem descriptions from piping syster (Fig. B.1)

\begin{tabular}{|c|c|c|c|c|}
\hline $\begin{array}{l}\text { Case } \\
\text { No. }\end{array}$ & Fluid & $\begin{array}{l}\text { Injected } \\
\text { fluid }\end{array}$ & Condition of feed at 1 in Fig. B.1 & $\begin{array}{l}\text { Condition of } \\
\text { injected feed }\end{array}$ \\
\hline 1 & $a$ & None & $\begin{array}{l}\text { Subcooled liquid at } 258.2 \mathrm{~K} \text { and } 689.5 \mathrm{kPE} \\
\left(5^{\circ} \mathrm{F} \text { and } 100 \mathrm{psia}\right)\end{array}$ & N/A \\
\hline 2 & $a$ & None & $\begin{array}{l}\text { Superheat } t \in d \text { vapor at } 283.2 \mathrm{~K} \text { and } 689.5 \mathrm{kPa} \\
\left(50^{\circ} \mathrm{F} \text { anc } 100 \text { psia }\right)\end{array}$ & $\mathrm{N} / \mathrm{A}$ \\
\hline 3 & $a$ & None & $\begin{array}{l}\text { Two-phase mixture at } 273.7 \mathrm{~K} \text { and } 689.5 \mathrm{kPa} \\
\left(3 \mathrm{~S}^{\circ} \mathrm{F} \text { and } 100 \mathrm{psia}\right)\end{array}$ & N/A \\
\hline 4 & $a$ & None & $\begin{array}{l}\text { Subcooled } 1 \text { iquid at } 269.3 \mathrm{~K} \text { and } 689.5 \mathrm{kPa} \\
\left(25^{\circ} \mathrm{F} \text { and } 100 \mathrm{psia}\right)\end{array}$ & $\mathrm{N} / \mathrm{A}$ \\
\hline 5 & $a$ & $b$ & $\begin{array}{l}\text { Subcooled liquid at } 269.3 \mathrm{~K} \text { and } 689.5 \mathrm{kPa} \\
(25.0 \mathrm{~F} \text { and } 100 \mathrm{psia})\end{array}$ & $\begin{array}{l}\text { Subcooled liquid } \\
\text { at } 272 \mathrm{~K} \text { and } \\
689.5 \mathrm{kPa}\left(30^{\circ} \mathrm{F}\right. \\
\text { and } 100 \mathrm{psia})\end{array}$ \\
\hline
\end{tabular}

\footnotetext{
$a_{\text {Ethane }}-0.605 \mathrm{~kg} / \mathrm{s}(80 \mathrm{lb} / \mathrm{min})$

Propene $-3.024 \mathrm{~kg} / \mathrm{s}(4 \mathrm{CO} \mathrm{1b} / \mathrm{min})$

Propane - $2.419 \mathrm{~kg} / \mathrm{s}(320 \mathrm{lb} / \mathrm{min})$

$b_{\text {Propene }}-0.756 \mathrm{~kg} / \mathrm{s}(1 \mathrm{CO} 1 \mathrm{~b} / \mathrm{min})$

Propane $-0.756 \mathrm{~kg} / \mathrm{s}(1 \mathrm{CO} 1 \mathrm{~b} / \mathrm{min})$
}

Note: In case 5, the injected fluid is introduced into the piping system in the 5-in. welding elbow. 
the piping system is shown in Fig. B.2. The code input for cases 1-4 is exactly the same except for the primary feed stream temperature. Since there are 20 control volumes in the model, there would be 33 total pages of FFFAP output for each sample problem. For case 5, the complete FFFAPVersion 1.0 outpat (a11 33 pages) will be given in Appendix B.7; however, for the remaining cases only pages 11 and 33 of the FFFAP output will be presented because these pages contain the initial and final state of the fluid in the system.

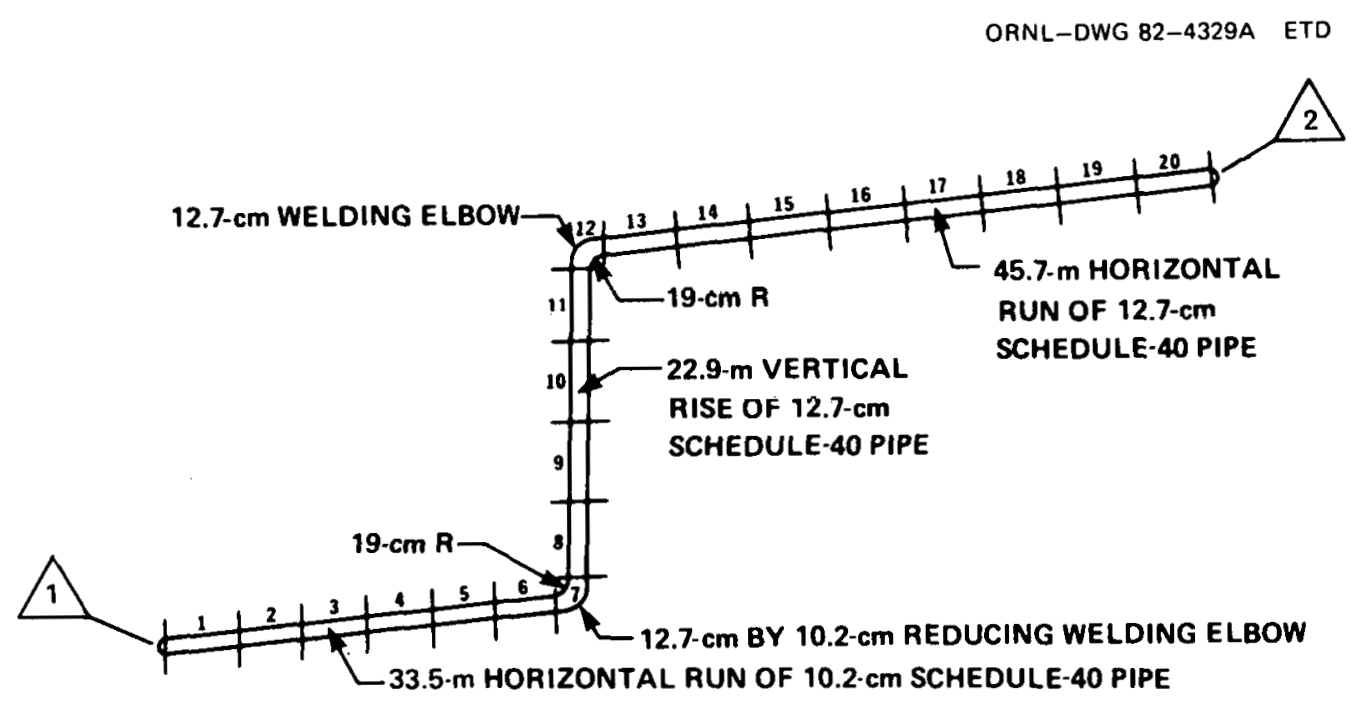

Fig. B.2. Control volume representation of piping system for sample problems. 
72

\section{THIS PAGE}

\section{WAS INTENTIONALLY}

LEFT BLANK 


\section{B.2 Code Input for Case 5}

The required code input for sample problem 5 is shown on the following page. The differences in the inputs for sample problems 4 and 5 are the following:

1. the 1 ast entry on card 101201 is 0 ,

2 . the entry on card 350001 is 0 , and

3. cards 350100-350102 are not included.

The only difference in the inputs for sample problems 1-4 is the primary feed stream temperature (the second entry on card 300001). 


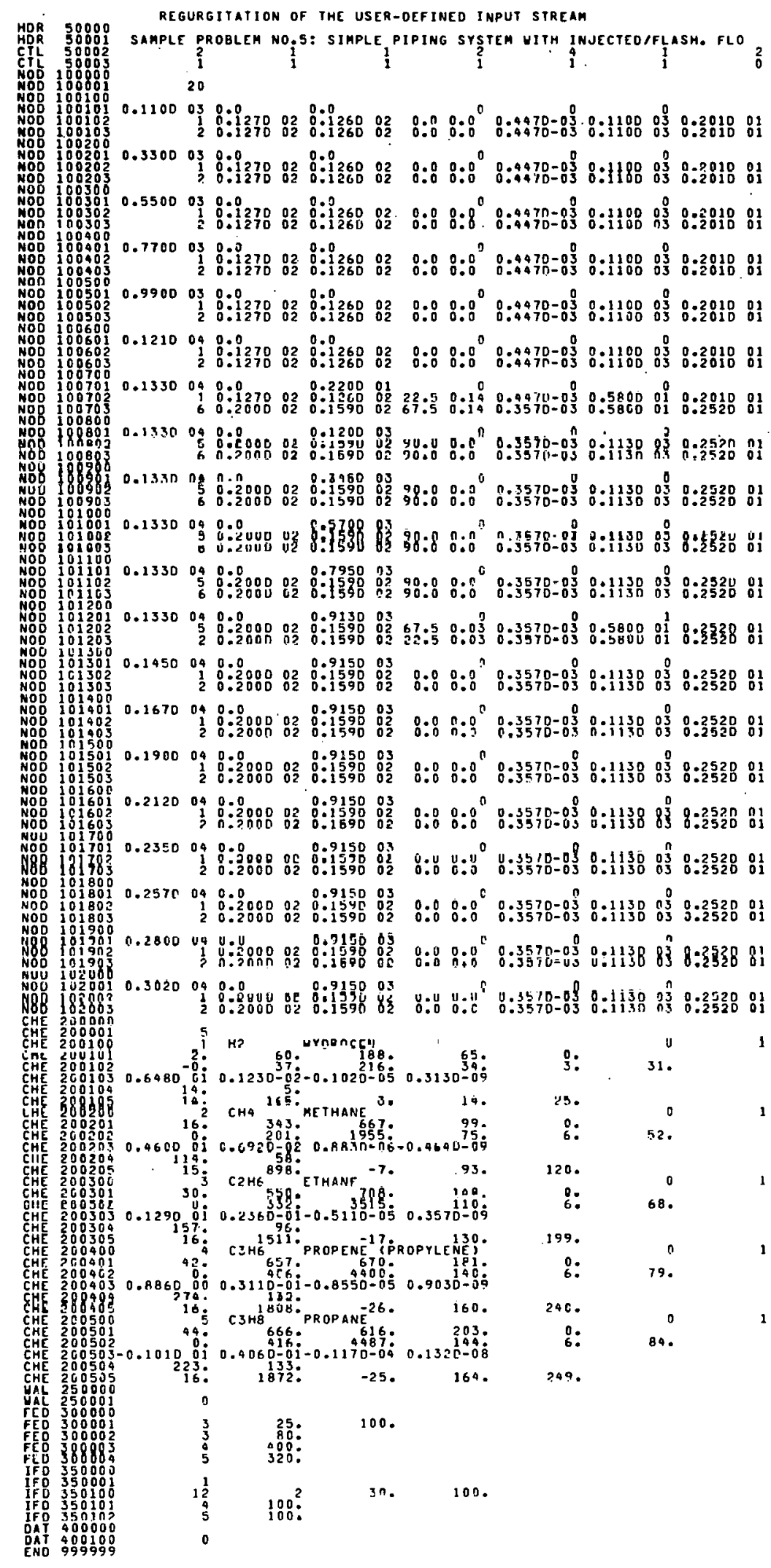




\section{B.3 Case 1: One-Phase (Liquid) Multicomponent Flow}

In case 1 , the fluid is $\sim 12.8 \mathrm{~K}\left(23^{\circ} \mathrm{F}\right)$ subcooled initially and remains subcooled throughout the piping system. The initial and final state of the fluid (points 1 and 2 in Fig. B.1, respectively) from the FFFAP outpat for this case are presented on the next two pages. In summary, a pressure drop of $128 \mathrm{kPa}(18.6 \mathrm{psi})$ and a temperature drop of $\sim 0.39 \mathrm{~K}$ $\left(0.7^{\circ} \mathrm{F}\right)$ occur between points 1 and 2 for case 1 . 
CONTEHTS OF THE PEED STREAM: ( 3 CONPONENTS)

a INDEX roRMULA DSER CBEMICAL NAME

$\begin{array}{lllll}1 & 3 & \text { C2H6 } & \text { ETHANE } \\ 2 & 4 & \text { C3H6 } & \text { PROFENE } \\ 3 & 5 & \text { C3H8 } & \text { PBOPANE } & \\ 3 & 5 & \end{array}$

FLOH FATE
(LBS/GIN)

$\begin{array}{rl}80.00 & 00 \\ 400.00 & 0\end{array}$

MOLECDLAR

(FLON RATR

FHACIJOA

0.1020
0.5050

30.07
42.08
44.10

2.600
9.505
7.257

0.1370
0.4894
0.3736

TOTAL UASS PLOW RATE $=$ TOOAO LBS/HIN

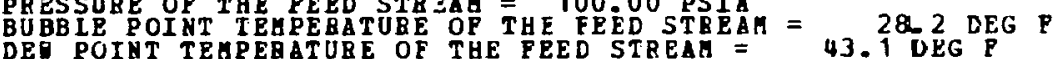

HEAT CONTENT OF THE LIUUID $=-131005.23$ ETU/HIN $=-163.76$ BFT $/$ LB

LIQUID DENSITY $=33.79$ LBU/CU.PT.

LIQUID VISCOSITY $=0.000075$ LBM 


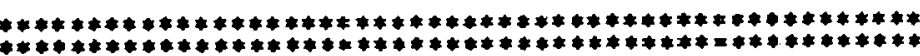 \\ * CONDITIOA (STATE) OP THE PRIAARY PEED STREAM ** \\ * CONDITION (STATE) OP THE PRIMARY PEED STREAM * \\ $* * * * * * * * * * * * * * * * * * * * * * * * * * * * * * * * * * * * * * * * * * * * * * * * * * *$}

CONTEATS OF THE FEEO STREAA: ( 3 COMPOH ZNTS)

n ingex formula user chemical bahe

$\begin{array}{lllll}1 & 3 & \text { C2H6 } & \text { ETHANE } \\ 2 & 4 & \text { C3H6 } & \text { PROPENE } \\ 3 & 5 & \text { C } 3 \text { (PRO } & \text { PEOPANE }\end{array}$

FLUN, RATE

80.00
400.00

TOTAL HASS PLOW AATE = 800. LBS/UIH 3 DEG

PRESSUAE OF THE FEED STREAH T O1.41 PSTA

STATE OR CONDITION OF THE PEED STREAL : SUBCOOLED LIQUID

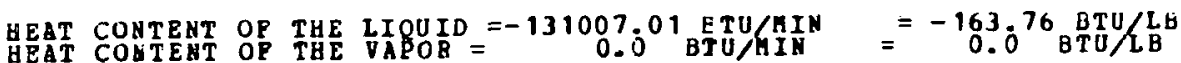

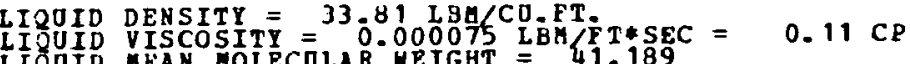

\begin{tabular}{|c|c|c|}
\hline $\begin{array}{l}\text { MEIGHT } \\
\text { PRACTIUN }\end{array}$ & $\begin{array}{l}\text { POL ECOLAD } \\
\text { WEIGAT }\end{array}$ & $\begin{array}{l}\text { PLOK RATE } \\
\text { (LBROLE/IIN) }\end{array}$ \\
\hline $\begin{array}{l}0: 1000 \\
0: 5000 \\
0: 4000\end{array}$ & $\begin{array}{l}30.07 \\
44: 07 \\
44: 10 \\
40\end{array}$ & $\begin{array}{l}2.600 \\
9=505 \\
7: 525\end{array}$ \\
\hline
\end{tabular}


78

\section{THIS PAGE}

\section{WAS INTENTIONALLY \\ LEFT BLANK}




\section{B.4 Case 2: One-Phase (Vapor) Mn1ticomponent Flow}

In case 2 , the fluid is $\sim 3.6 \mathrm{~K}\left(6.5^{\circ} \mathrm{F}\right)$ superheated initially and, like the fluid in case 1 , remains one-phase through the system. The FFFAP results (pages 11 and 33 ) are given on the next two pages. For this case, there is (1) an overall pressure drop of $242.7 \mathrm{kPa}(35.2 \mathrm{psi})$ and (2) a temperature drop of $2.39 \mathrm{~K}\left(4.3^{\circ} \mathrm{F}\right)$. 


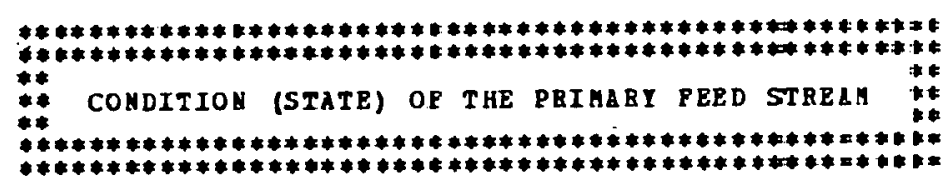

COYT EYTS OP THE PEED STEEAH: ( 3 COHPONENTS)

Y INDEX FORUULA USER CHEHICAL NARZ

$\begin{array}{lllll}1 & 3 & \text { C2H6 } & \text { RTHANE } \\ \frac{1}{2} & 4 & C 3 H 6 & \text { PROPENE } \\ 3 & 5 & \text { C3H8 } & \text { PROPANE } & \text { (PBOPYLEN.) }\end{array}$

FLOM RATE

90.000
400.00

320.00
HEIGHT
PHACTION

0.1000

0.4000

\section{MOL ECULAR}

30: 07

44.10
(LEOHOLETITIN)

9.660
EK ACL

0.1370

TOTAL HASS FLON RATE $=$ 800.0 LBS/RIN

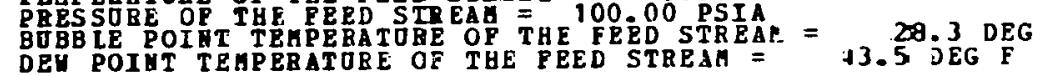
STATE OB COHDITION OP THE FEED STREAH : SEPERAEATES VAPOF

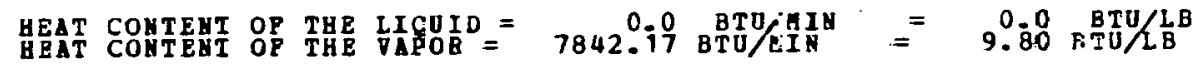

VAPOR DENSITY $=0.8528$ ZBM/CU.PT

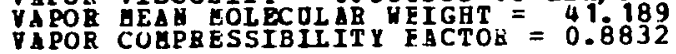

*SBC $=0.85389 \mathrm{DD}-02 \mathrm{CP}$ 


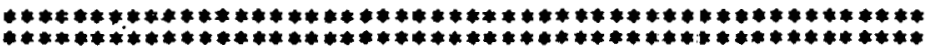 \\ * CONDITION (STATE) OP THE PRIHARY PEED STREAh

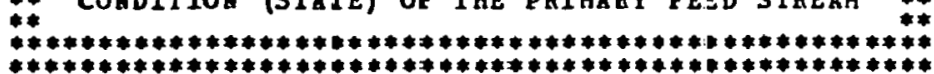

COBTEHTS OP THE FEED STREAH: ( 3 CONPONEHTS)

Y IUDEX PORAULA USER CHEMTEAL NAME

$\begin{array}{lllll}1 & 3 & \text { C2H6 } & \text { PTHANE } \\ 2 & 4 & \text { CHH6 } & \text { PROPE PE } \\ 3 & 5 & \text { C } 3 H 8 & \text { PROPANE }\end{array}$

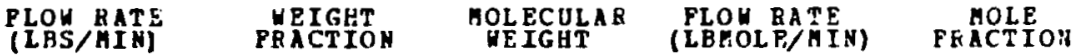

$\begin{array}{rrrrr}80.00 & 0.1000 & 30.07 & 2.660 & 0.1370 \\ 400.00 & 0.5000 & 42.08 & 9.505 & 0.4894 \\ 320.00 & 0.4000 & 44.10 & 7.257 & 0.3736\end{array}$

STREAH $=6475,7$ DEG $P$

GQESSURE OP T HE PEED STREA

STATE OB COADITION OP THE PEED STREAa : SOPERHEATED VAPOR

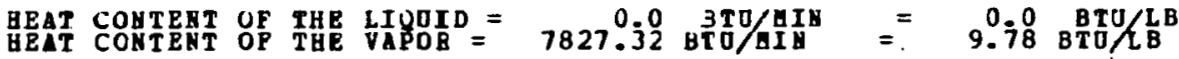

YAPOR DENSITT $=0.5319$ LBH/CD $\mathrm{PT}$ PTPT

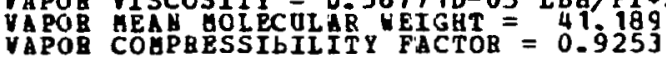




\section{2}

\section{THIS PAGE}

\section{WAS INTENTIONALLY LEFT BLANK}




\section{B.5 Case 3: Two-Phase (Vapor/Liguid) Multicomponent Flow}

At the initial conditions of $273.7 \mathrm{~K}\left(33^{\circ} \mathrm{F}\right)$ and $689.5 \mathrm{kPa}$ (100 psia), the fluid in case 3 is two-phase with the weight fraction of the feed stream being vapor equal to 0.1628 . There is (1) an overall pressure loss of $155.8 \mathrm{kPa}(22.6 \mathrm{psi}),(2)$ a temperature drop of $8.1 \mathrm{~K}\left(14.6^{\circ} \mathrm{F}\right)$, and (3) an increase in the fraction vaporized to 0.2064 . The FFFAP results (pages 11 and 33) are given on the next two pages. 


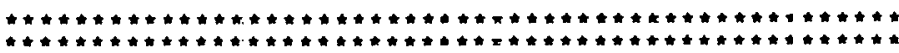 \\ \# CONDITION (STATE) OF THE PRIMARY FEed STREAM :

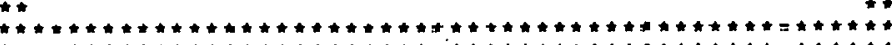

CONTENTS OF THE FEED STREAM: ( 3 COMFONENTS )

$N$ INDEX FORMULA USER CHEMICAL NAME

$\begin{array}{llll}1 & 3 & \text { C2HG } & \text { ETHANE } \\ 2 & 4 & \text { C } 3 H 6 & \text { PROPFNE APROPYLENE } \\ 3 & 5 & \text { C } 3 H 8 & \text { PROPANE }\end{array}$

TOTAL MASS FLOU RATE $=300.0$ LBS

TERPERATURE OF THETEED STREAM

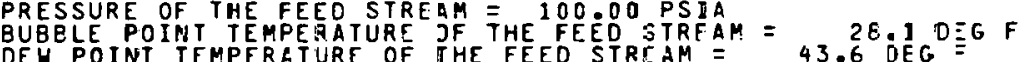

THE FEED STREAM IS TWO-PHASE AND HAS IHE FOLLDHING YAPOR/LICUIO SPLIT:

$$
\text { COMP JNENT }
$$

ETHANE (PROPYLENE)

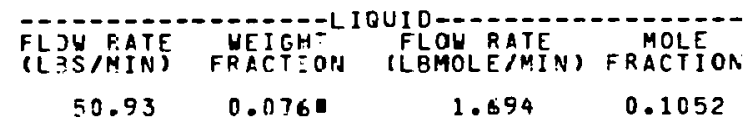

$\begin{array}{llll}50.93 & 0.076: & 1.094 & 0.1052 \\ 340.14 & 0.5078 & 8.083 & 0.5022 \\ 278.70 & 0.416: & 6.327 & 0.3927\end{array}$

TOTAL LJOUID MASS FLOW RATE = 669.78 LBSIMIN

WEIGHT FRACTION OF THE FCED STREAM TMAT TS VAPOR $=0.1628$

HEAT CONTENT OF THE LIOUTO $=-101098.66$ BTU/MIN $=-150.94$ BT'J/LB

HETAL HEAT CONTENT OF THE STREAM $=-100852.56$ BTU/MIN

LIOUIO OENSITY $=32.52$ OBMACU.FT'

IOUIO MEAN

VAPOR DENSITY $\overline{\bar{Y}}=0.8385$ LBM:CU.FT

VAPOR YISCOSITY $=0.571030-15$ LBHAFT

VAPOR/LIOUIO INTERFACIAL. SURFACE. TENSION $=0.550350-03$ LBF/FT $=$

B.031 DYNERCM

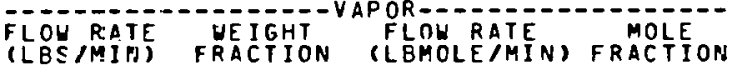

$\begin{array}{ccccc}\text { FLOH RATE } & \text { MEIGHT } & \text { MJECULAR } & \text { FLOH RATF } & \text { MMOLE } \\ \text { (LBSIMIN) } & \text { RACIION } & \text { JEIGHT } & \text { ILSMOLEIMIN) } & \text { FRACTION } \\ 80.00 & 0.1000 & 30.07 & 2.660 & 0.1370 \\ 400.00 & 0.5000 & 42.08 & 9: 505 & 0.4994 \\ 320.00 & 0.4000 & 44.10 & 7.257 & 0.3736\end{array}$




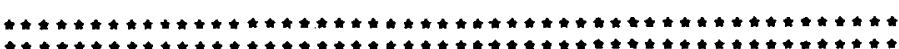

: CONOITION (STATE) DF THE PRIMARY FEED STREAM :

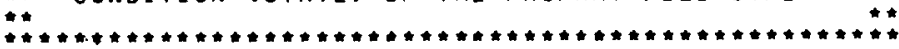

CONTENTS OF THE FEED STREAM: ( 3 COMPONENTS)

$N$ INDEX FORMULA USER CHEMICAL NAME

$\begin{array}{llll}1 & 3 & \text { C2H6 } & \text { ETHANE } \\ 2 & 4 & \text { C3 } 36 & \text { PROPENE } \\ 3 & 5 & \text { C } 3 H 8 & \text { PROPANE }\end{array}$

FLOH RATE MEIGHT MOLECULAR FLOH RATE
(LESIMINS FRACTION MEIGHT MOLE

$\begin{array}{rllll}80.00 & 0.1000 & 30.07 & 2.660 & 9.1370 \\ 400.000 & 0.5000 & 42.08 & 9.505 & 0.4894 \\ 320.00 & 0.4000 & 44.10 & 7.257 & 0.3736\end{array}$

TOTAL MASS FLOWRATE E 800 TE LBS/MIN

PRESSURE OF THE FEED STREAM

THE FEED STREAM IS THO-PHASE AND HAS THE FOLLOUING VAPOR/LIOUIO SPLIT:

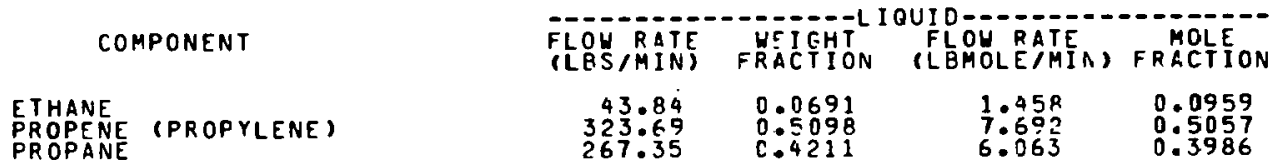

\begin{tabular}{|c|c|c|c|}
\hline $\begin{array}{l}\text { FLOU RATE } \\
\text { (LOS,MIN) }\end{array}$ & $\begin{array}{l}\text { UEIGHT } \\
\text { FOACTION }\end{array}$ & $\begin{array}{l}\text { FLOU } \\
\text { (LERTIMINS }\end{array}$ & FRACTION \\
\hline $\begin{array}{l}35: 16 \\
75: 3 \frac{1}{1} \\
52: 65\end{array}$ & $\begin{array}{l}0.2190 \\
0.4622 \\
0.3188\end{array}$ & $\begin{array}{l}1.282 \\
1: 914 \\
1.194\end{array}$ & $\begin{array}{l}0.2 \\
0: 4 \\
0.2\end{array}$ \\
\hline
\end{tabular}

TOTAL LIOUID MASS FLOH RATE $=634.88$ LBSIMIN
TOTAL VAPOR HASS FLOURATE $=165.12$ LBSTININ
WEIGHT FRACTION OF THE FEED STREAM THAT IS VAPOR $=0.2064$

HEAT CONTENT OF THE LIQUID $=-100616.07$ BTU/MIN $=-158.48$ BTU/LB

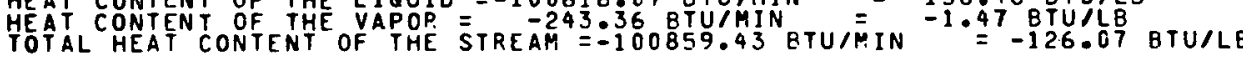

LIOUID OENSITY $\overline{\bar{N}}=33.36$ LBM/CU FT'

VAPOR DENSITY $=0.6556$ LBM/CU.FY F

VAPOR MEAN MOLECULAR WEIGHT $=39.207$

VAPOR/LIOUID INTERFACIAL SUFFACE TENSION $=0.622860-03$ LBF/FT =

9.089 DYNE/CM 
86

\section{THIS PAGE}

\section{WAS INTENTIONALLY LEFT BLANK}




\section{B.6 Case 4: F1ashing Mn1ticomponent F1ow}

In case 4 , the fluid is $\sim 1.8 \mathrm{~K}\left(3.2^{\circ} \mathrm{F}\right)$ subcooled initially and remains subcooled until control volume 9 (Fig. B.2), where the computed bubble-point temperature falls below the primary stream temperature and thus flashing occurs. Flashing initiates in node 9, and additional vaporization continues through node 20. The initial and final states of the fluid for case 4 are presented on the next two pages. Overa11, there is (1) a pressure drop of $\sim 107.6 \mathrm{kPa}$ (15.6 psi), (2) a temperature drop of $3.1 \mathrm{~K}\left(5.6^{\circ} \mathrm{F}\right)$, and (3) a weight fraction vaporized of 0.054 . 


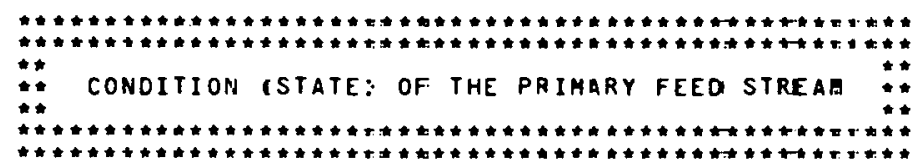

CONTENTS DF THE FEED STREAM: 13 COMPONENTS

$N$ INDEX FORIILA USER CHEMICAR NAME

$\begin{array}{llll}1 & 3 & \text { C2HG } & \text { ETHANE } \\ 2 & 4 & \text { CYHG } & \text { PROPENE } \\ 3 & 5 & \text { C } 3 H 8 & \text { PROPANELENE: }\end{array}$

\begin{tabular}{|c|c|c|c|}
\hline $\begin{array}{l}\text { LOU, RATE } \\
\text { LASMINI }\end{array}$ & $\begin{array}{l}\text { FEYGHT } \\
\text { FRACTION }\end{array}$ & $\begin{array}{l}\text { 4OLECULAR } \\
\text { WEIGHT }\end{array}$ & 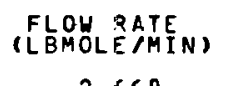 \\
\hline $\begin{array}{rl}800 & 0 \\
4000 \\
320 \\
320 \\
0.00\end{array}$ & 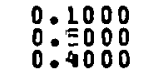 & $\begin{array}{l}30: 07 \\
4208 \\
44.10\end{array}$ & $\begin{array}{l}2: 660 \\
9: 565 \\
7: 257\end{array}$ \\
\hline
\end{tabular}

TOTAL MASS FLOW RATE

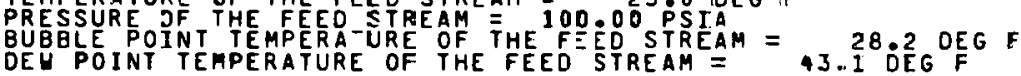

STATE OR CONDITION OF THE FEED STREAM : SUBCOOLCE LIOUIO

HEAT CONTENT OF THE LIQLID $=-119577.66$ BTU/MIN $=-149.43$ BTU/LB

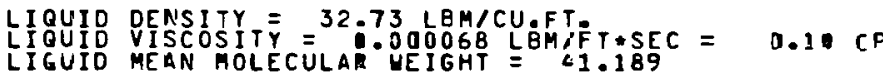




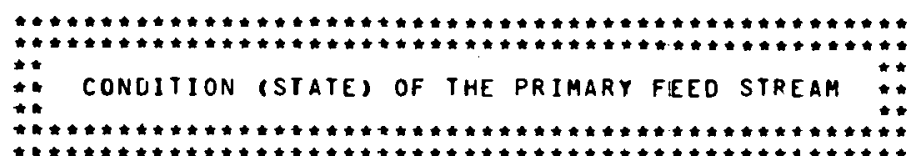

CONTENTS OF THE FEED STREAM: ( I COMPONENTS)

N INDEX FORMIJLA USER CHEMICAL NAME

$\begin{array}{llll}1 & 3 & \text { C2HG } & \text { ETHANE } \\ 2 & 4 & \text { C } 3 H 6 & \text { PROPENE } \\ 3 & 5 & \text { C } 3 H B & \text { PROPANE }\end{array}$

\begin{tabular}{|c|c|c|c|c|}
\hline $\begin{array}{l}\text { FLOH,RATE } \\
\text { (LESIMINS) }\end{array}$ & FEEIGHT & $\begin{array}{l}\text { MOLECULAR } \\
\text { WEIGHT }\end{array}$ & $\begin{array}{l}\text { FLON RATE } \\
\text { (LEMOLEIMIN) }\end{array}$ & $\begin{array}{l}\text { MOLEE } \\
\text { FRACTION }\end{array}$ \\
\hline 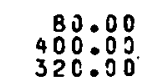 & $\begin{array}{l}0.1000 \\
0.5000 \\
0.4000\end{array}$ & $\begin{array}{l}30.07 \\
42: 08 \\
44.10\end{array}$ & $\begin{array}{l}2.660 \\
0: 505 \\
7.257\end{array}$ & $\begin{array}{l}0.1370 \\
0.4894 \\
7.3736\end{array}$ \\
\hline
\end{tabular}

TOTAL MASS FLOW RATE $=800 \%$ LBSIMIN:

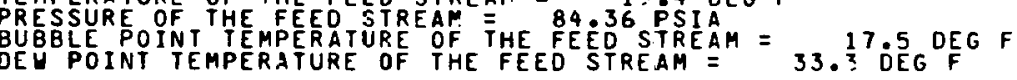

THE FEED STREAM IS TWD-PHASE AND HAS THE FOLLOUING VAPOR/LIQUID SPLIT:

\begin{tabular}{|c|c|c|c|c|c|c|c|c|}
\hline COMPONENT & $\begin{array}{l}\text { FLOU RATE } \\
\text { (LSSIMINI }\end{array}$ & FPACTION & $\begin{array}{l}\text { FLOY RATE } \\
\text { (LBMOLEIMIN) }\end{array}$ & FRACTION & $\begin{array}{l}\text { FIOURATE } \\
\text { CLSIMIN) }\end{array}$ & $\begin{array}{l}\text { WEAGHT } \\
\text { FRACTION }\end{array}$ & $\begin{array}{l}\text { FLOWORATE } \\
\text { (LEMOLETMIN) }\end{array}$ & FRACTION \\
\hline $\begin{array}{l}\text { ETANE } \\
\text { PROPENE (PROPYLENE) } \\
\text { PROPANE }\end{array}$ & $\begin{array}{l}68.29 \\
381: 15 \\
307: 29\end{array}$ & $\begin{array}{l}0.0902 \\
0: 5037 \\
0.0061\end{array}$ & $\begin{array}{l}2.271 \\
9: 058 \\
6.969\end{array}$ & $\begin{array}{l}0.1241 \\
0: 4951 \\
0.3809\end{array}$ & $\begin{array}{l}11: 71 \\
18: 85 \\
12: 71\end{array}$ & $\begin{array}{l}0.2705 \\
8: 4354 \\
0.2937\end{array}$ & $\begin{array}{l}0.389 \\
8: 448 \\
0.288\end{array}$ & $\begin{array}{l}0.3455 \\
0: 3974 \\
0.2557\end{array}$ \\
\hline
\end{tabular}

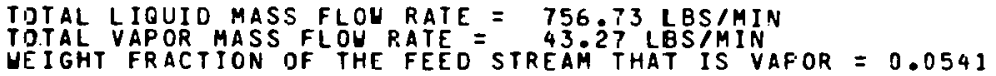

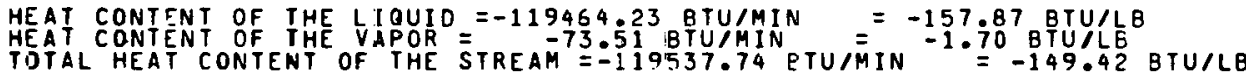

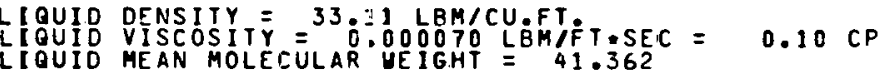

VAPOR DENSITY $\overline{\bar{C}}=0.7015 \mathrm{LBM} / \mathrm{CU}$.FT

VAPOR MEAN MOLECULAR WEIGHT = 38.387

VAPOR/LIOUIO INTERFACIAL SURFACE TENSION $=0.606550-03$ LBF/FT $=8.851$ DYNE/CM 
90

THIS PAGE

WAS INTENTIONALLY

LEFT BLANK 


\section{B.7 Case 5: F1ashing Multicomponent F1ow with an Injected Side Stream}

The initial set-up for case 5 is the same as for case 4 . In fact, the calculational results are the same through control volume 11; however, an injected side stream is then introduced into control volume 12, thus causing differences in case 4 and 5 calculations downstream of control volume 12. The complete 33-page FFFAP output for this case is presented in the following pages. 


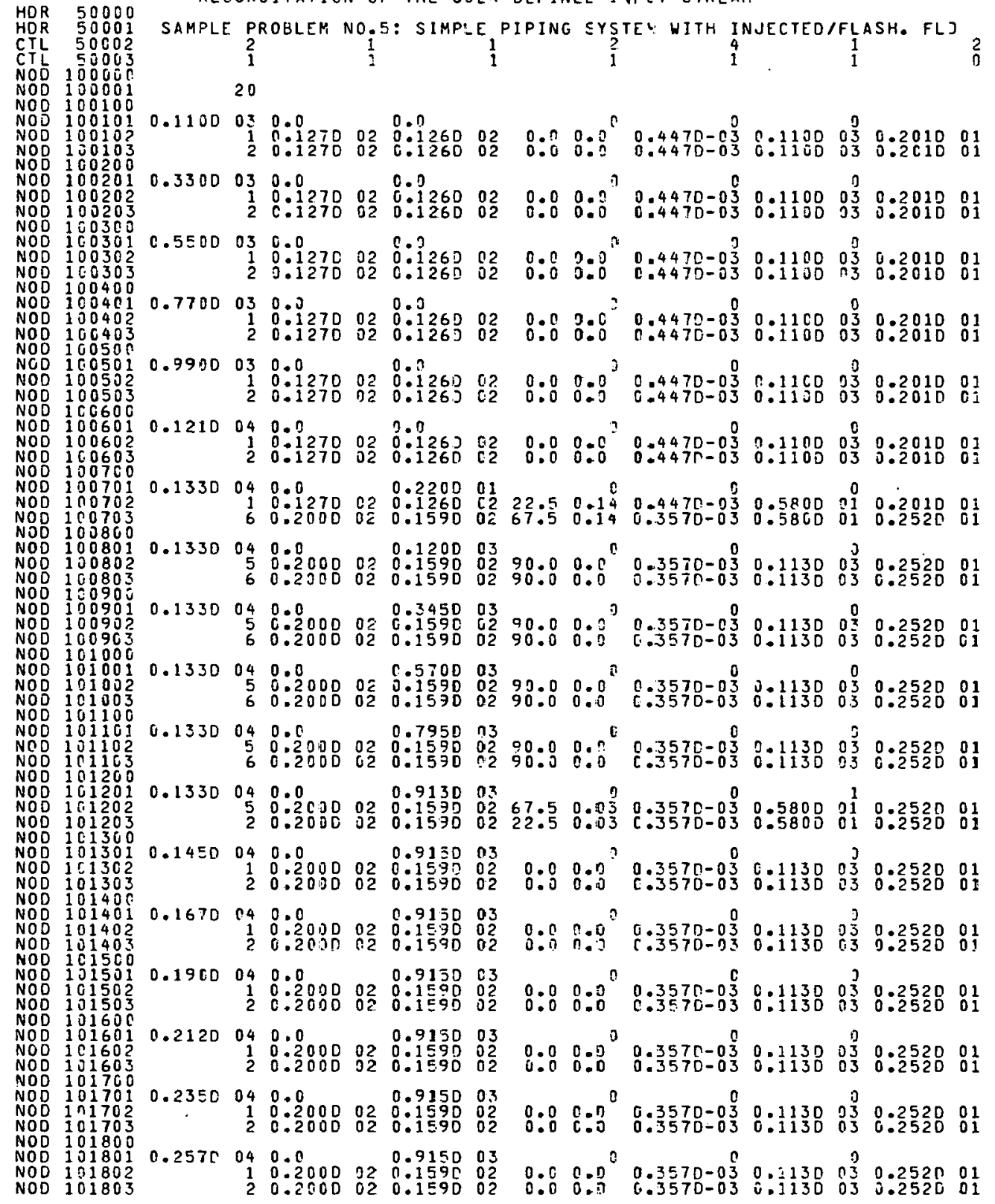




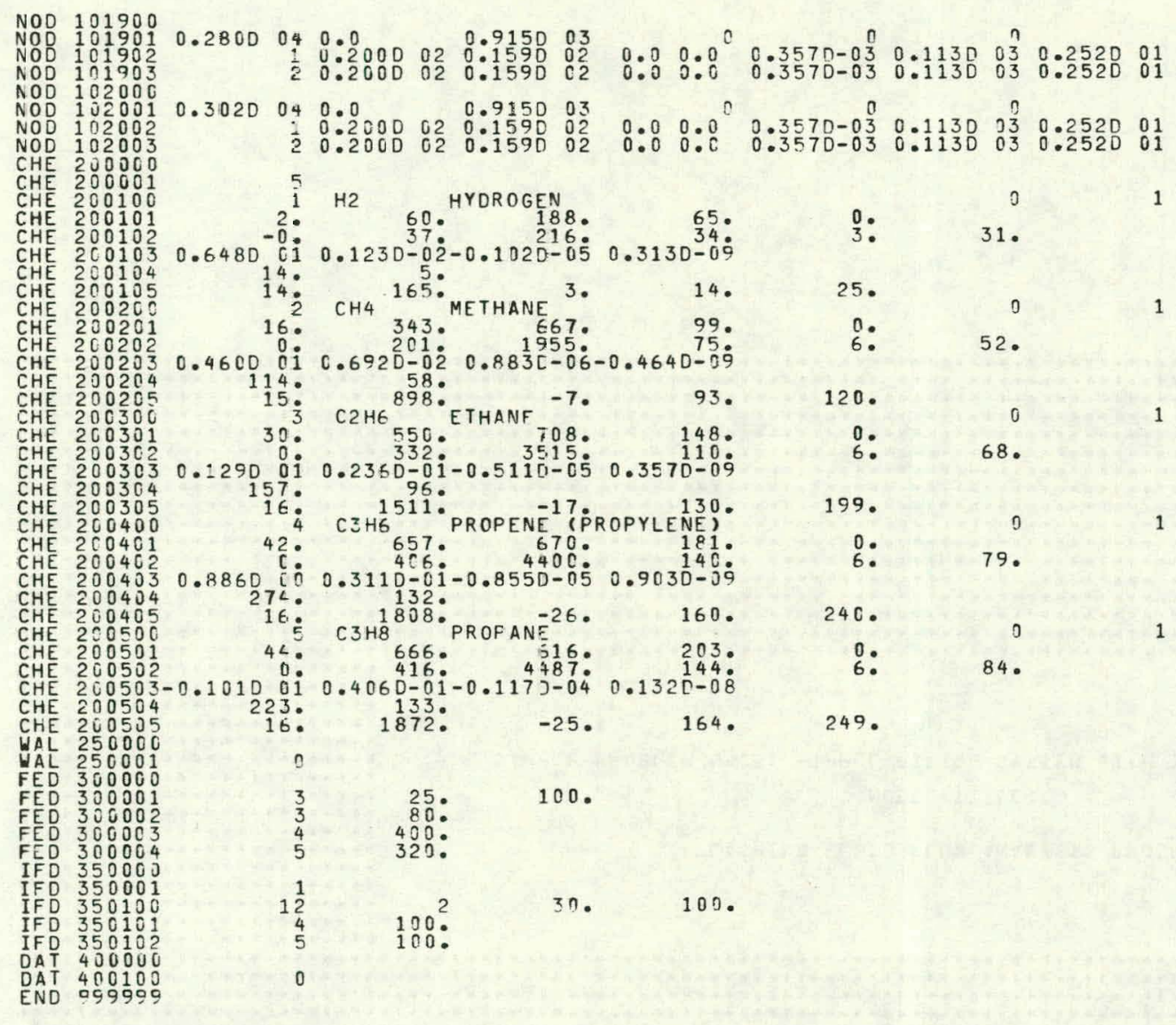




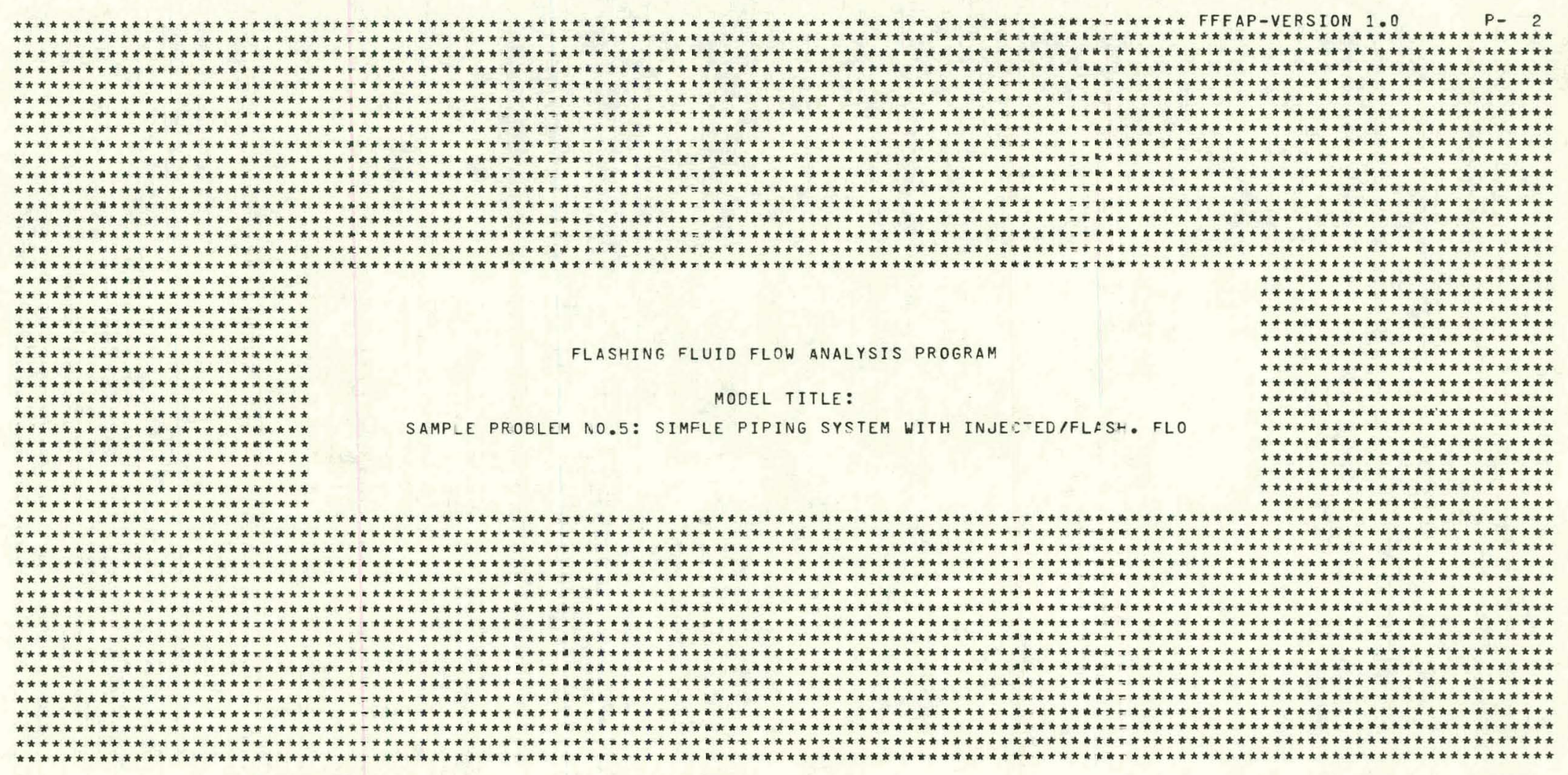




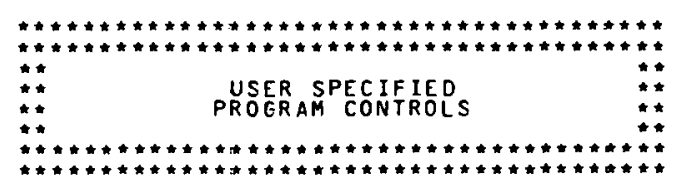

FFFAP-VERSION 1.0

CONTROL VARIABLES ARE SPECIFIED ON CARDS 50002 ANO 50003 GF THE USER GENERATEO PROGRAM INPUT.

CONTROL
VARIABLE

EXPLANATION

ICS(1)

FLASH TECHNIQUE:

STATUS

INPUT DEFAULT
VALUE

ICS(2)

ENTHALPY CALCULATIONS:

$=1$
$=2$
$=2$

NOT AVAILABLE

I Cs ( 3$)$

YEN $=1$
$=2$
$=3$

$\operatorname{Ics}(3)$

BUBBLE AND DEW POINT CALC:

$=1$
$=2$
$=2$

NOT AYAILABLE

ICS (4) FRICTIIONAL CORFEL: FOR
VERTICAL SLURRY F:OH:

ICS (5)

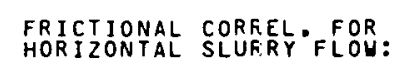

ICS (6)

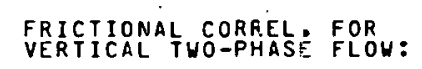

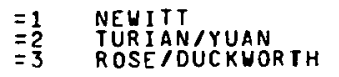

$=1$ NEHITT

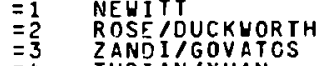

$=1$ ORKISZEUSKI

ICS (7)

FRICTIONAL COPAEL FOR
HOR IZONAL TWOPHISE FLOU:

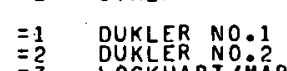

DUKLER NO 2
$=2$
$=2$
$=2$

FRICTIONAL CORREL: FOR
SINGLE PHASE FLOW:

$\operatorname{ICS}(8)$

SINGLE PHASE FLON:

I $\operatorname{cs}(9)$

I Cs $(10)$

LIEUID HOLDUP CORREL. FOR

$=1$
$=2$
$=2$

$=\frac{1}{2}$ HUGHMARK

LIOUID HOLDUP CORREL. FOR
HORIZONTAL FLOH:

$=1$ HUGHMARK

DUKLER
$=2$
$=3$
$=$

$\operatorname{Ics}(11)$

COMPUTATION OF LIOUID
VISCOOSTYY

$=1$
$=2$
$=2$

ICS (12) COMPUTATION OF LIQUID DENSITY

I Cs (13)

CHUEH PPPAUSNITZ

$=1$
$=2$
$=2$
NOT AVAILABLE

NOT AVAILABLE

NOT AVAILAELE

NOT AVATLABLE
NOT AVAILABLE

NOT AVAILABLE

NOT AVAILABLE

NOT AVAILABLE

NOT AVAILABLE 


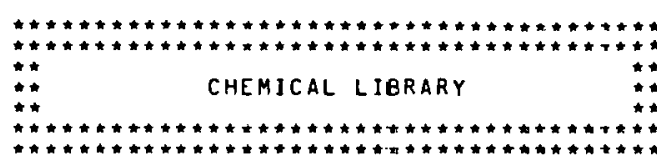

THERE IS A, TOTAL OF 5 EHEMICAL COMFOUNOCS, IN THE CLLFREN L:BRARY.

$N$ INDEX FORMULA

N IVDEX FORML

PCRIT VCRIT ZCRIT OMEGP.

TBOI: HFGB PARACHOR SOL

VML

$1 \quad 1 \quad H 2$

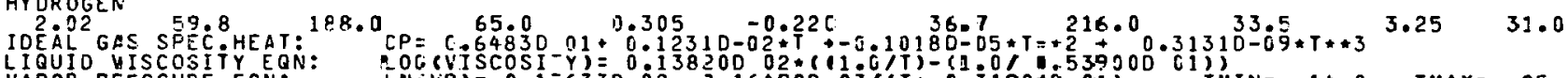

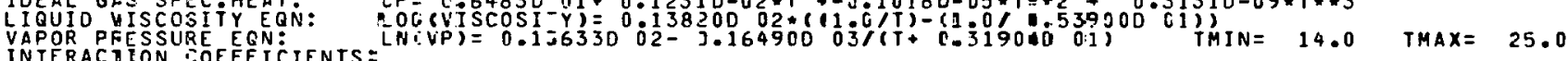
ALL.EQ.0.0, EXCEPT FOR THOSE NOTED.

$2 \quad 2 \quad \mathrm{CH} 4$

ME THANE

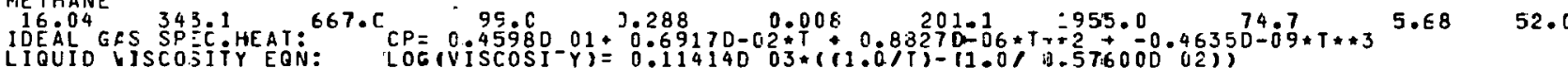

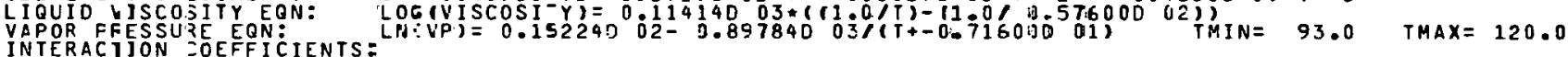
ALL.EQ.C.O. EXCEPT FOR THOSE NOTED.

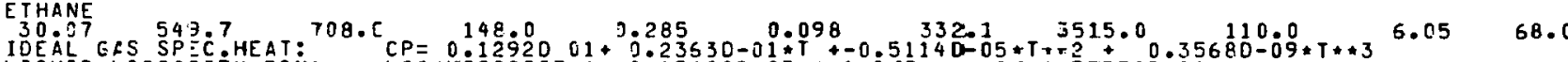

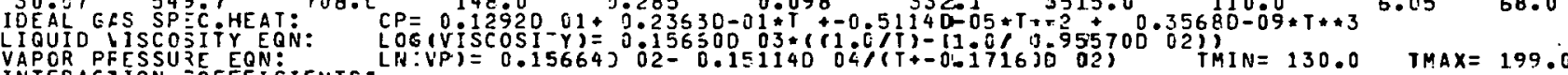
INTERACIION SOEFFICIENTS:

$4 \quad 4 \quad C 3 H 6$

PROPENE (PROPYLENE)

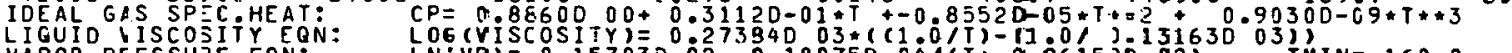

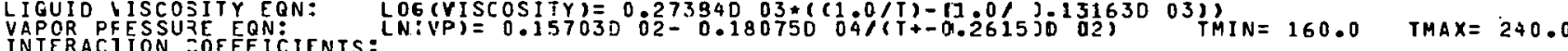
$A L L . E Q .0 .0$, EXCEPT FOR THOSE NOTED.

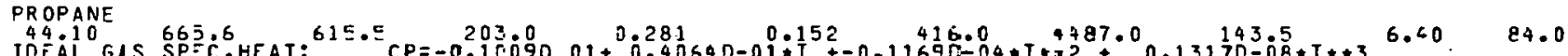

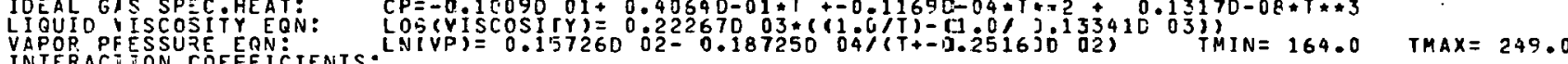
ETS: 


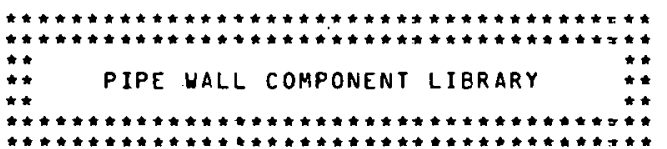

\section{THERE IS A TOTAL OF O PIPE HALL COMPONENTS IN THE CURRENT LIBRARY}

THERMAL CONDUCTIVITY TEMPERATURE FIT 


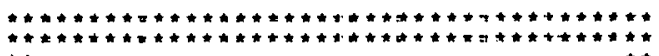

\# EXPERIMENTAL DATA. SETS

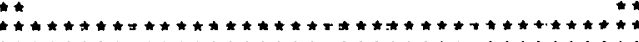

THERE IS A TOTAL OF O EXPERIBENTAL DATA SET(S) IN IHE CUREENT JOB INPUT.

$N$ NODF PRESSURE TEMPERATURE FLOW DENSITY 


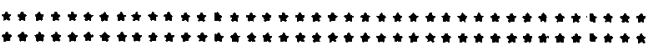

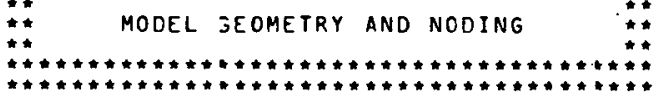

FFFAP-VERSION 1.0

P- 7

THERE IS A TOTAL OF 20 CONTROL VOLUMES IN THE CURRENT MODEL.

NODE $X$

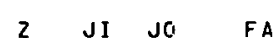

FAO WPI WPO
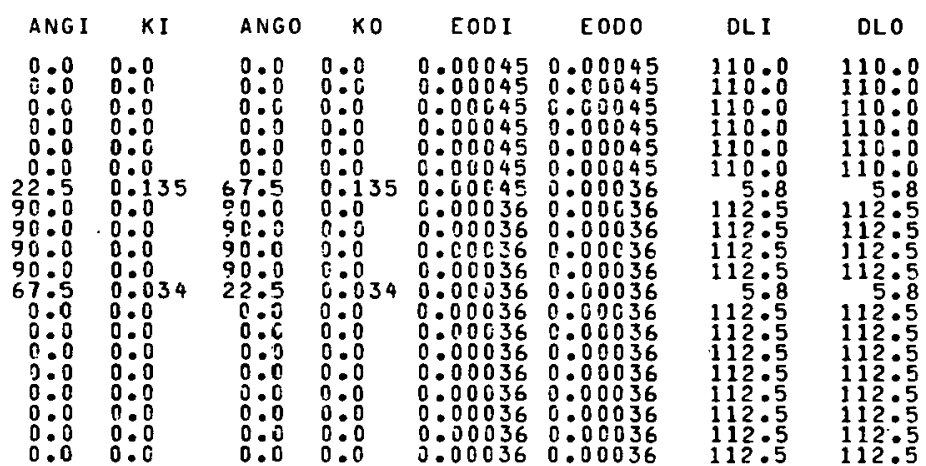
MODEL GEOMETRY AN) NODING (CONTINUED):

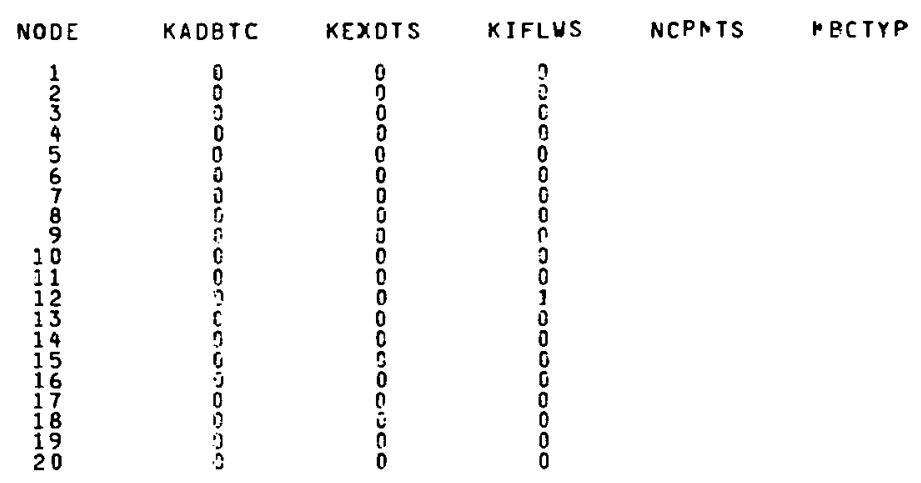




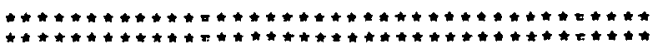

* primari ano injected feed streams :"

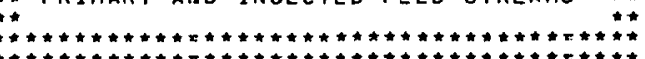

PRIMARY FEED STREAM:

THERE IS A TOTAL OF 3 CHEMICAL COMPOUNR(S) IN THE CURRENT MODEL.

EED STREAM PRESSURI $=$ IOT. 0 PSE IAEG F

N INOEX FORMULA USER CHEMICAL NAME

$\begin{array}{llll}1 & 3 & \text { C2H6 } & \text { ETHANE } \\ \frac{1}{2} & 4 & \text { C3H6 } & \text { PFOPENE (PROPYLENE) } \\ 3 & 5 & \text { C3H8 } & \text { PFOPANE }\end{array}$

MASS FLOU RATE

80.00
5000000 
INJECTED FEED STREAMS:

THERE IS A TOTAL OF 1 INJECTED FEED STREAHS IN THE CURRENT MODEL.

STREAM NO STREAM TEMPERATURE INJECTED IN NOOE 12 AND HAS A TOTAL OF 2 CHEMICAL COMPOUNDS. STREAM TEMPERATURE $=0.30$ PO DEG

$N$ INDEX FORMULA USER CHEMICAL NAME

MASS FLOU RATE

$\begin{array}{llll}\frac{1}{2} & 4 & \text { C } 3 H 6 & \text { PROPENE } \\ 2 & 5 & \text { C } 3 H 8 & \text { PROPANE }\end{array}$

100000
100000 


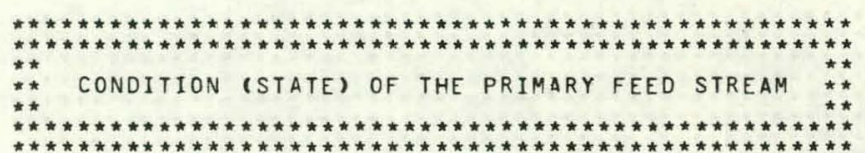

CONTENTS OF THE FEED STREAM: ( 3 CCMPONENTS)

\begin{tabular}{|c|c|c|c|c|c|c|c|}
\hline N INDEX & FORMULA & USER CHEMICAL NAME & $\begin{array}{l}\text { FLOH RATE } \\
\text { (LESIMIN) }\end{array}$ & $\begin{array}{l}\text { HEIGHT } \\
\text { FRACTION }\end{array}$ & $\begin{array}{l}\text { MOLECULAR } \\
\text { WEIGHT }\end{array}$ & $\begin{array}{l}\text { FLOW RATE } \\
\text { (LBMOLEMMIN) }\end{array}$ & $\begin{array}{l}\text { MOLE } \\
\text { FRACTION }\end{array}$ \\
\hline $\begin{array}{l}3 \\
4 \\
5\end{array}$ & $\begin{array}{l}\text { C2 } 2 \mathrm{H} 6 \\
\text { C3 } 3 \mathrm{HG} \\
\mathrm{C} 3 \mathrm{H} 8\end{array}$ & $\begin{array}{l}\text { ETHANE } \\
\text { PROPENE (PROPYLENE) } \\
\text { PROPANE }\end{array}$ & $\begin{array}{l}80.000 \\
400: 05 \\
320.00\end{array}$ & $\begin{array}{l}0.10000 \\
0.50000 \\
0.4000\end{array}$ & $\begin{array}{l}30: 07 \\
42: 08 \\
44: 10\end{array}$ & $\begin{array}{l}2.660 \\
0: 505 \\
7.257\end{array}$ & $\begin{array}{l}0.1370 \\
0.13894 \\
0.03736\end{array}$ \\
\hline
\end{tabular}

TOTAL MASS FLOW RATE $\bar{E}$ TEMPERATURE COF THE FEED STREAM LBS M IN

DEW POINT TEMPERATURE OF THE FEED STREAM = 43.18 DEG FEG F

STATE OR CONEITION OF THE FEED STREAM : SUBCOOLED LIQUID

HEAT CONTENT OF THE LIQUID $=-119547.66$ BTU/MIN $=-149.43$ BTU/LE

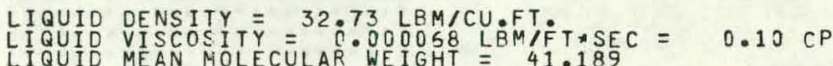




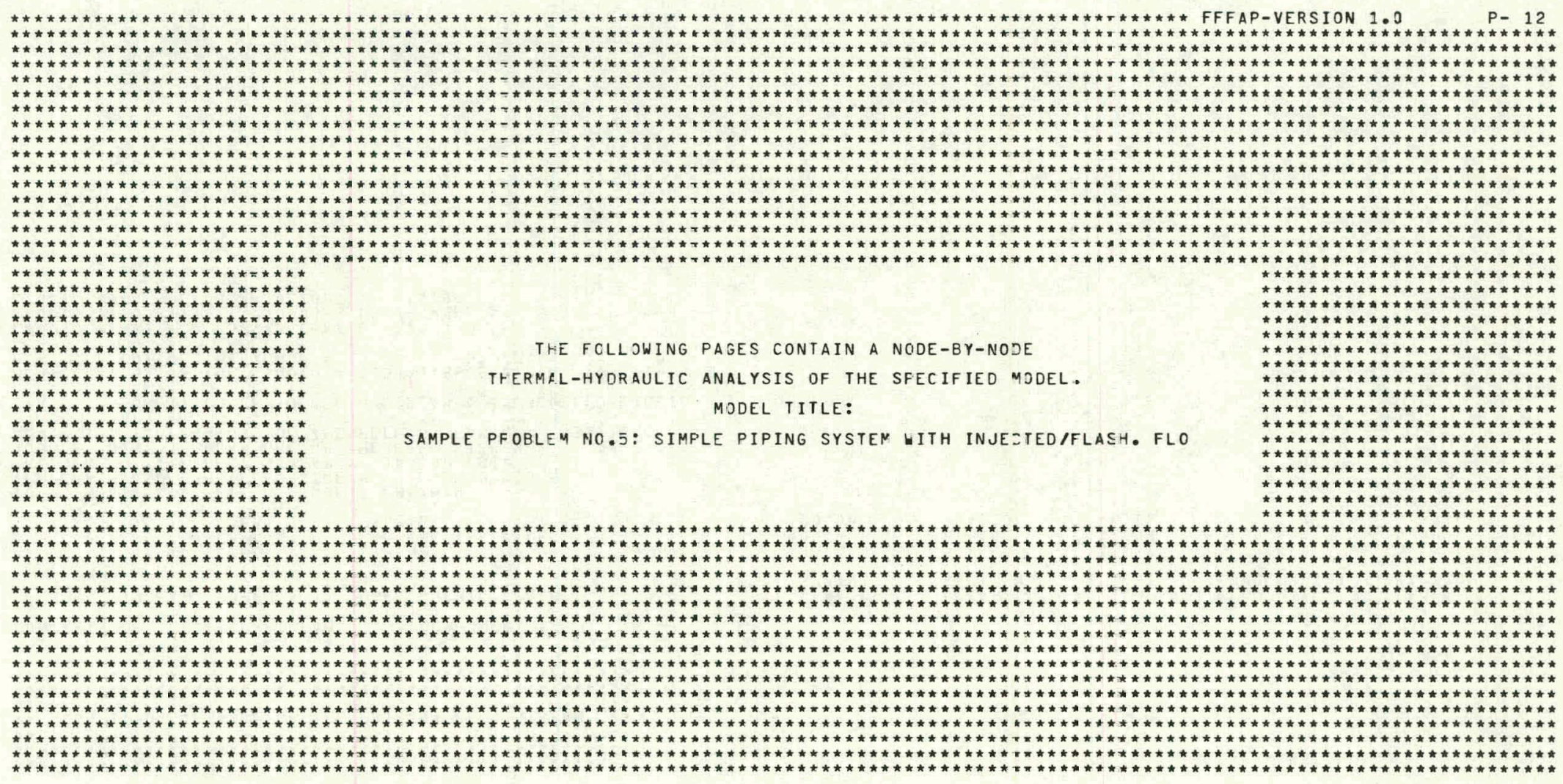




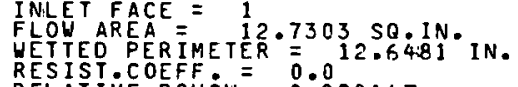

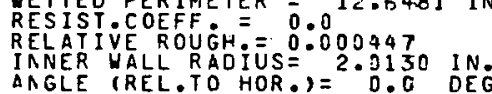

\section{EEPERIMENTAL DATA: NO}

CONTENTS OF THE PRIMARY STREAM: ( 3 COMPONENTS)

$N$ INDEX FORMULA USER CHEMICAL NAME

\begin{tabular}{llll}
1 & 3 & C2HG \\
2 & 4 & C $3 H G$ \\
3 & 5 & C3HE & ETHANE \\
\hline
\end{tabular}

TOTAL MASS FLOH RATE $=800.0$ LBS/MTN

TEMPERATURE OF THE PRIMARY STREAM = 25 .0 CES F

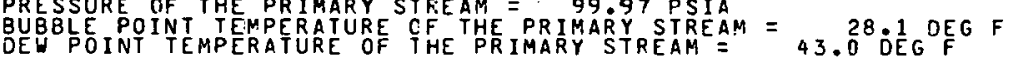

STATE OR CONOITION OF THE PRIMARY STREAM : SUBCOOLEO LIOUID

HEAT CONTENT OF THE LIQUID $=-119547.66$ RTUMMIN $=-149.043$ BTU/LB

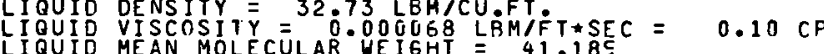

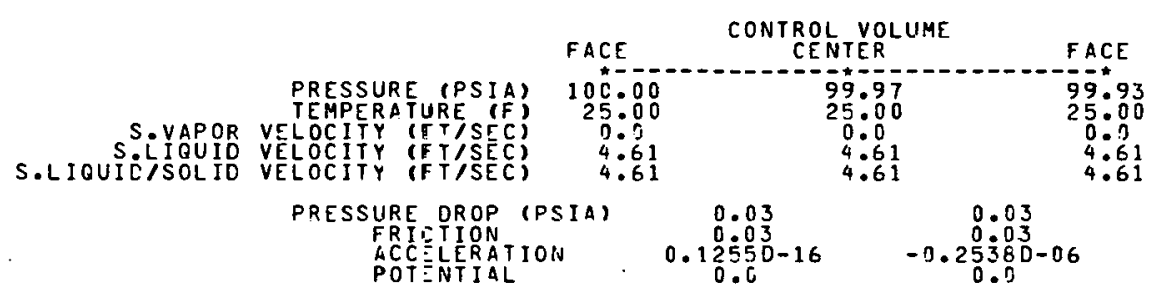

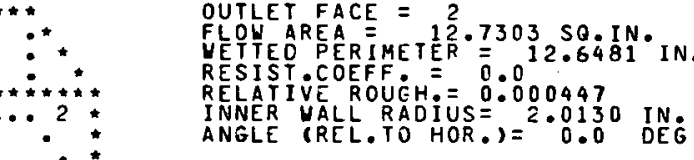

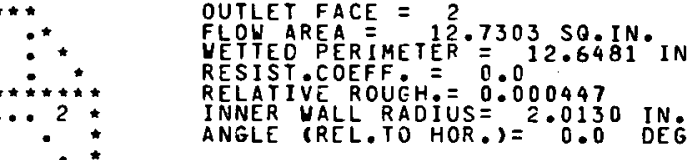

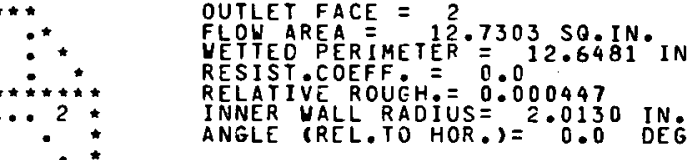

\begin{tabular}{|c|c|c|c|}
\hline $\begin{array}{l}\text { FLOU RATE } \\
\text { (LOSTHIN) }\end{array}$ & $\begin{array}{l}\text { HEIGHT } \\
\text { FRACTION }\end{array}$ & MOLEECULAR & $\begin{array}{l}\text { FLOH RATE } \\
\text { (LBMOLE EMIN) }\end{array}$ \\
\hline $\begin{array}{rl}80 & 09 \\
400 & 90 \\
320000\end{array}$ & $\begin{array}{l}0.1000 \\
0: 5000 \\
0: 4000\end{array}$ & $\begin{array}{l}30: 07 \\
42: 08 \\
44: 10\end{array}$ & $\begin{array}{l}2.660 \\
97505 \\
7.257\end{array}$ \\
\hline
\end{tabular}




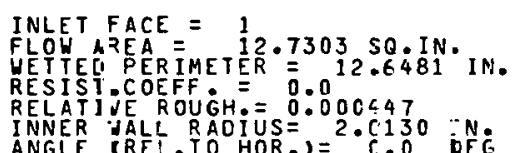
RENER JALL RADIUS $=2 . C 130$ ON
ANGLE IREL. TO HOR.)

\section{EXPERINENTAL DATA: NO
INJECTED FELON:
ADIABATC: NO}

CONTENTS OF THE PRIMARY STFEAM: $(3$ IOMPONEVTSI)

$N$ INGEX FORAULA USER CHE.MICAL NAME

$\begin{array}{llll}1 & 3 & \text { C2HG } & \text { ETHANE } \\ 2 & 4 & C 3 H 6 & \text { PROPENE } \\ 3 & 5 & C 3 H 8 & \text { PROPANE }\end{array}$

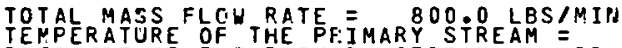

源

DEW POINT TEMPERATURE OF THE PRIMARY STREAF $=43.2811$ DEG F

STATE OR CONDITION OF THE PRIMARY STREAM : SUECODLED LIQUID

HEAT CONIENT OF THE LIQUID $=-119547.68$ ETUIMIN $=-149.43$ BTUMLB

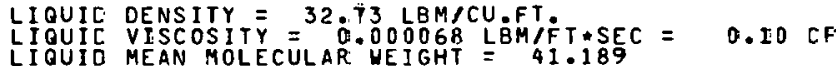

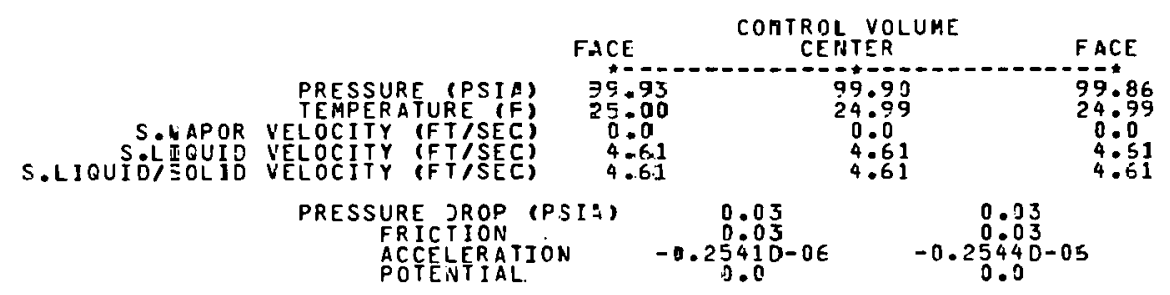

\begin{tabular}{|c|c|}
\hline 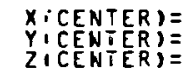 & $\begin{array}{ccc}330.0000 & \text { IN. } \\
0: 0 & \text { IN } \\
0.0 & \text { IN }\end{array}$ \\
\hline FLCWU LENGTH & I FLOH LENGTH \\
\hline $110.0000 \mathrm{IN}$ & $110.00001 \mathrm{I}$ \\
\hline
\end{tabular}

OUTLET FACE $=12.7303$ SQIIN.

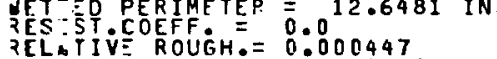

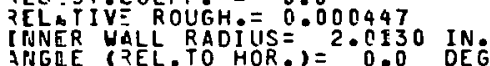




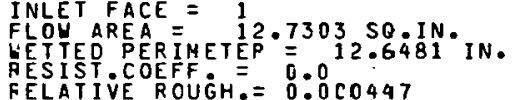
FELLATVEROUGH $=0.000447$ INNER WALL RADIUS $=2.0130$ IN.

\section{EXPERIMENTAL DATA: NO
INJECTED FLOW: NOS}

CONTENTS OF THE PRIMARY STREAM: $(3$ COMPONENTS

$N$ INCEX FORMULA USER CHEMICAL NAME

$\begin{array}{llll}1 & 3 & C 2 H 6 & \text { ETHANE } \\ \frac{2}{2} & 4 & \text { C3HG } & \text { PROPENE (PROPYLENE) } \\ 3 & 5 & \text { C3H8 } & \text { PROPANE }\end{array}$

TOTAL MASS FLOH RATE $=800.0$ LBS/MIN

TEMPERATURE OF THE PRIMARY STREAM = 25 B DODG F

BUBLE POINT TEMPERATURE OF THE PRIMMRY STREAM $=428.1$ OEG F

STATE OR CONDITION OF THE PRIMARY STREAM : SUBCOOLEO LIQUIO

HEAT CONTENT DF THE LIQUID $=-119547.70$ BTUMMIN $=-149.43$ BTU/LB

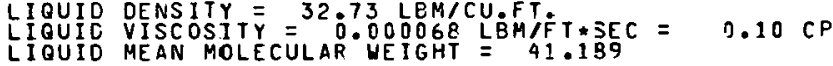
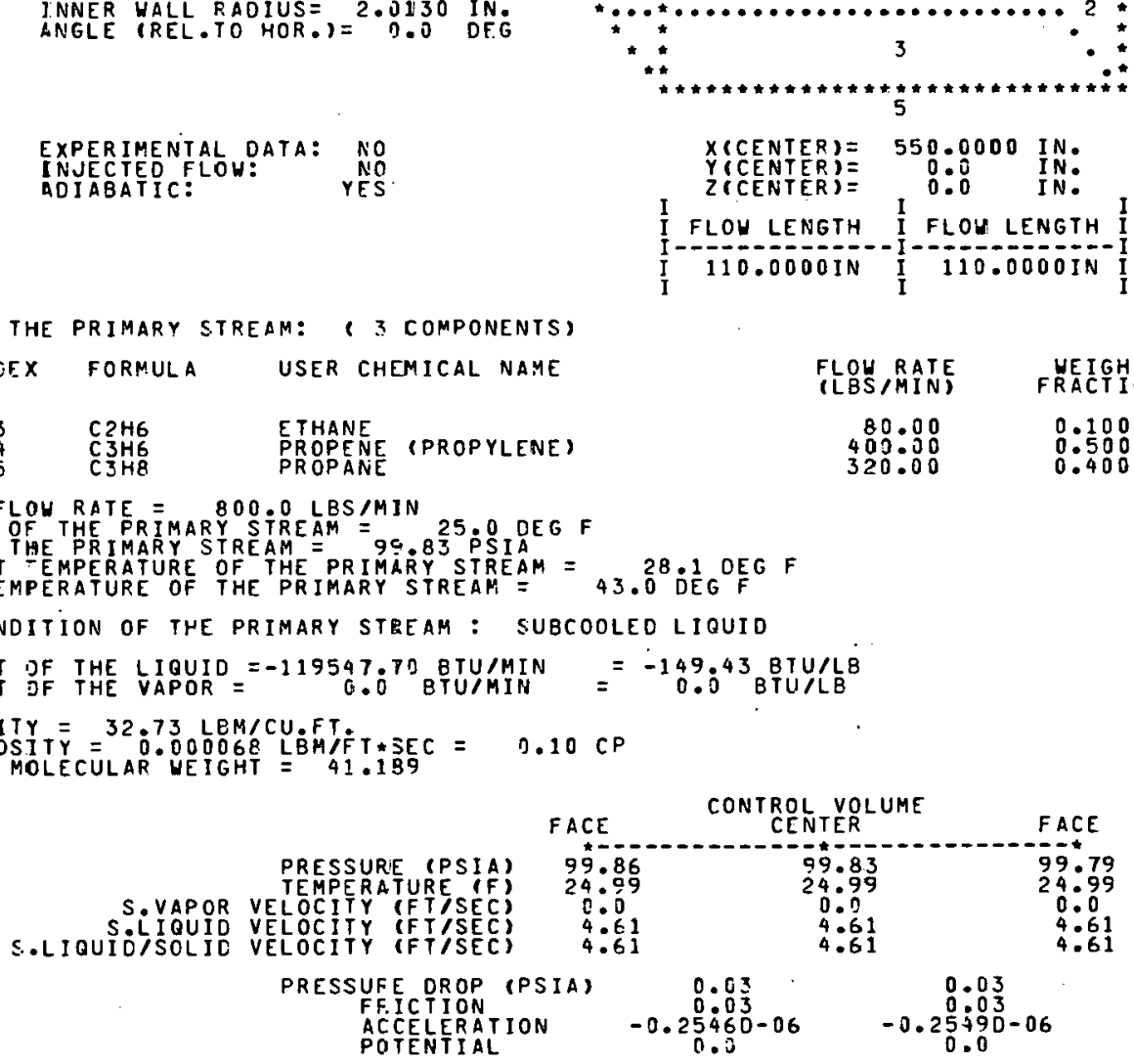

OUTLET FACE = 2 27303 SQ.IN.

RESIST COEFF = 0.000047

INNER WALL RADIUSS= 2.0130 IN.

\begin{tabular}{|c|c|c|c|}
\hline $\begin{array}{l}\text { FLOU, RATE } \\
\text { CLBS,MIN) }\end{array}$ & $\begin{array}{l}\text { WEIGHT } \\
\text { FRACTION }\end{array}$ & $\begin{array}{c}\text { MOLECULAR } \\
\text { WEIGHT }\end{array}$ & $\begin{array}{l}\text { FLOU RATE } \\
\text { (LBMOLEMMIN }\end{array}$ \\
\hline $\begin{array}{l}80.000 \\
400 \\
320000\end{array}$ & $\begin{array}{l}0.1000 \\
0: 5000 \\
0: 4000\end{array}$ & $\begin{array}{l}30: 07 \\
420 \\
44: 10\end{array}$ & $\begin{array}{l}2: 600 \\
7: 065 \\
7: 257\end{array}$ \\
\hline
\end{tabular}




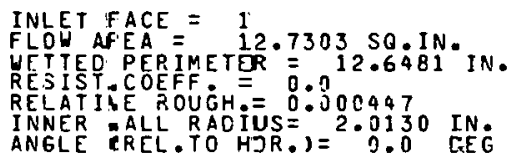

EXPERIAENTAL DATA: NO
INJECTED FLOH:
ADIABAIC: NO

CONTENTS OF THE PRIMARY STREAF: 13 COMPOAENTS

$N$ INDEX FORMULA LSER CHEMICAL NAME

$\begin{array}{llll}1 & 3 & \text { C2HG } & \text { ETHANE } \\ 2 & 4 & \text { C } 3 H 6 & \text { FROPENE } \\ 3 & 5 & \text { C } 3 H 6 & \text { PROPANE }\end{array}$

TOTAL MASS FLON RATE = 800 OOLBSIMIN

TEMESSURE OF THE PHE PRIMAPY STREAM = 25 , 25 MEE: $F$

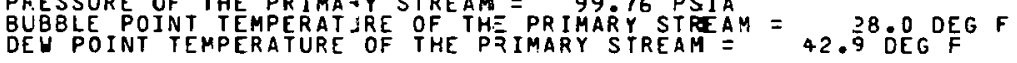

STATE OR ZONEITIOH OF THE PRIMARY SIREAM : SUBZCOLED LIQUID

HEAT CDNTENT OF THE L TOUID $=-119547.71$ ETUMMIN $=-149.0^{43}$ BTUMLB

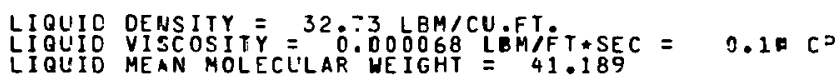

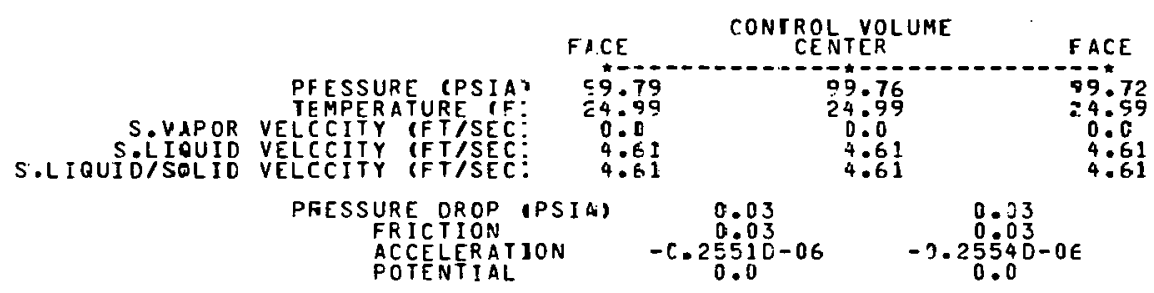

$X(C E N T E R)=770.0000$ IN
Y(CENTER)

Z(CENTER) $=10.0$ IN.
I FLON LENGIH I FLOU LENGTH I I
I I $113.0000 I N$ I I

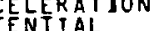

OUTLETFACE. $=22.7303$ S0.IN.

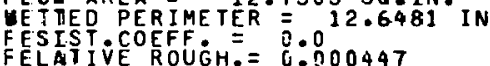

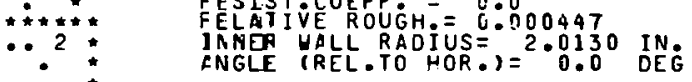


FFFAP-VERSION 1.0

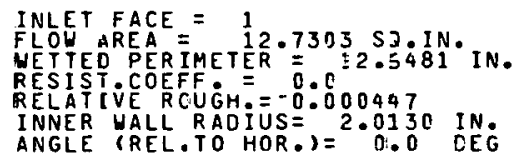

EXPERIMENTAL DATA: NO
INUECTED FELOE:
ADIABAIC:

CONIENTS OF THE PRIMARY STREAM: $(3$ COMPONENTS

$N$ INDEX FCRMULA USER CHIMICAL NAME

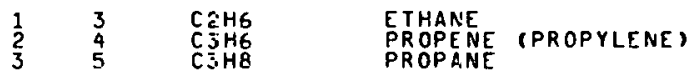

TOTAL MASS FLOW RA-E $=800.0$ LBS/MIN

TEMPERATURE OF THE PRIMARY STREAM = 25 . D DEG F

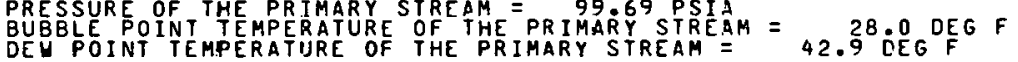

STATE OR CONDITION OF THE PRIMARY STREAM : SUBCOOLEO LIQUID

MEAT CONTENT OF THE LIQUID $=-119547.73$ BTUMMIN $=-149.43$ BTULLB

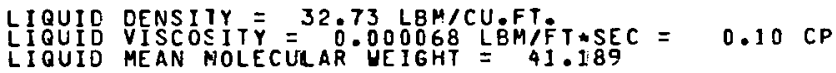

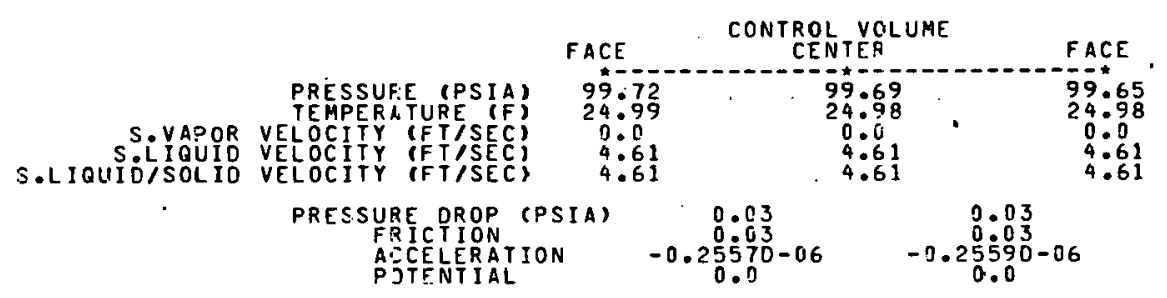

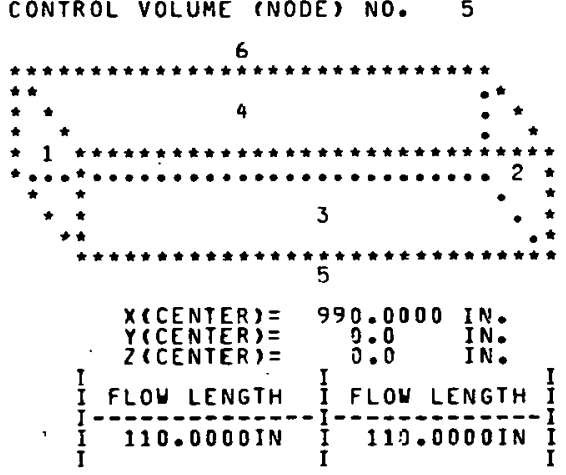

\begin{tabular}{|c|c|c|c|c|}
\hline $\begin{array}{l}\text { FLOV, RATE } \\
\text { (LOSIMIN) }\end{array}$ & $\begin{array}{l}\text { HEIGHT } \\
\text { FRACTION }\end{array}$ & $\begin{array}{l}\text { MOLECULAR } \\
\text { WEIGHT }\end{array}$ & $\begin{array}{l}\text { FLOY RATE } \\
\text { (LBMOLEMIIN) }\end{array}$ & $\begin{array}{l}\text { MOLE } \\
\text { FRACTION }\end{array}$ \\
\hline $\begin{array}{r}8000 \\
400 \\
320: 00\end{array}$ & $\begin{array}{l}0: 100 \\
0: 500 \\
0: 4000\end{array}$ & $\begin{array}{l}40: 07 \\
44: 108\end{array}$ & $\begin{array}{l}9: 50 \\
7: 5050\end{array}$ & $: 989$ \\
\hline
\end{tabular}




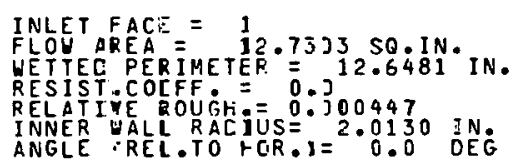

$\because *$

$1 *$

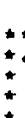

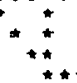

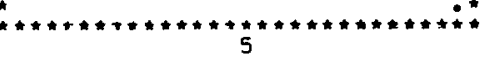

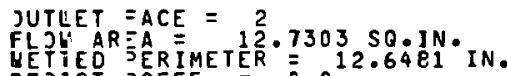
RESTST OOEFF =

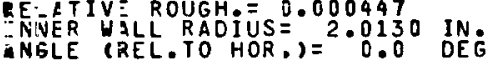

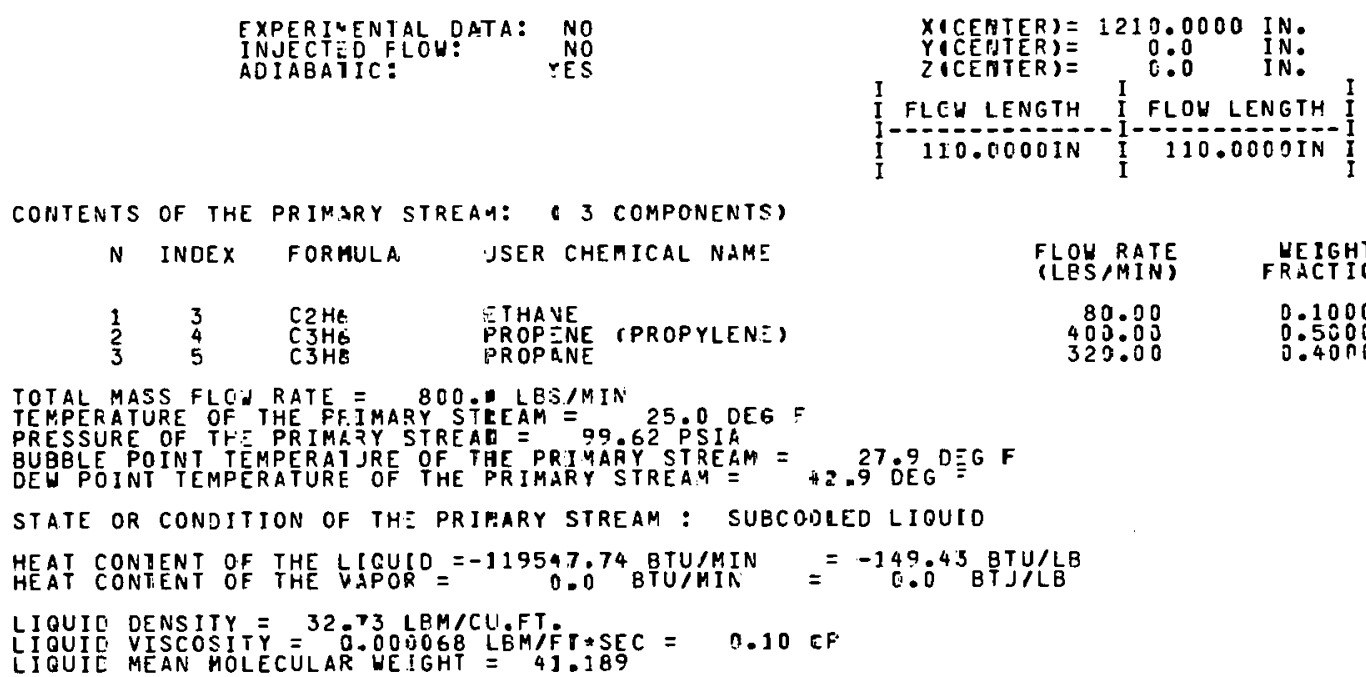

\section{EXPERIYENTAL DATA: NO
INJECYEDCLOW: NO
ADIABAIC:}

CONTENTS OF THE PRIMARY STREAM: I 3 COMPONENTS

N INOEX

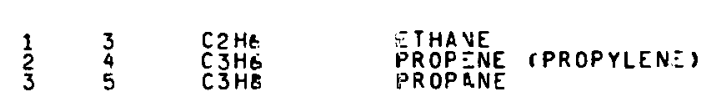

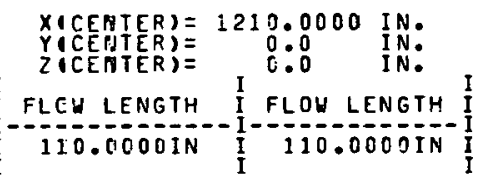

TOTAL MASS FLCOARATE

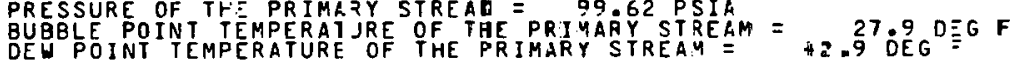

STATE OR CONDITION OF THE PRIPARY STREAM : SUBCODLED LIOUID

HEAT CONDENT OF THE LICULO $=-119547.74$ BTUMMIN $=-149.43$ BTUMLB

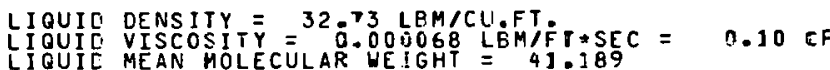




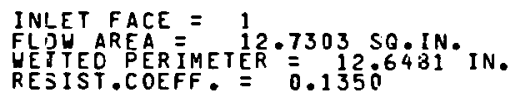
RELATIVEROUGH:=

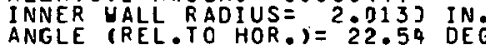

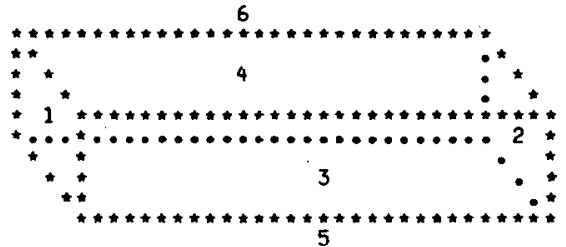

OUTLET FACE $=26.0058$ SQ.IN.

WETTEOPERIMETER $=15.8556$ IN

RESIST COEFF $=0.1350$

RE
INNER WALL RADIUS $=2.5235$ IN.
ANGLE TRO TOROR $=267.46$ OEG

EXPERMENTAL DATA: NO
INUECTED FLOW:
ACIABATIC:

CONTENTS OF THE PRIMARY STREAM: I 3 COMPONENTS

$N$ INDEX FORMULA USER CHEMECAL NAME

$\begin{array}{llll}1 & 3 & \text { C2H6 } & \text { ETHANE } \\ 2 & 4 & \text { C } 3 H 6 & \text { PROAE } \\ 3 & 5 & \text { P } 3 H 8 & \text { PROPANE (PROPYLENE) }\end{array}$

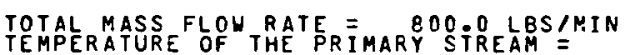

PRESSURE

BEH POINT TEMPERATURE OF THE PRIMAR! STREAMAM =

$42 .{ }^{27} \dot{D E G} \mathrm{DEF}^{\circ} \mathrm{F}$

STATE OR CONOITION OF THE PRIMARY STREAM : SUzCOOLED. LIQUID

HEAT CONTENT OF THE LIQUIO $=-119547.77$ ETUMMIN $=-149.43$ BTULLB

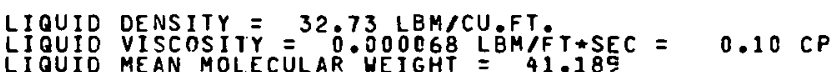

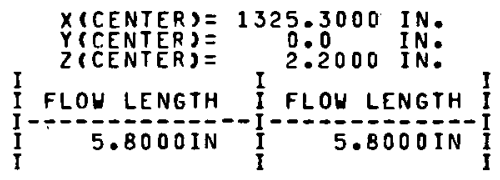

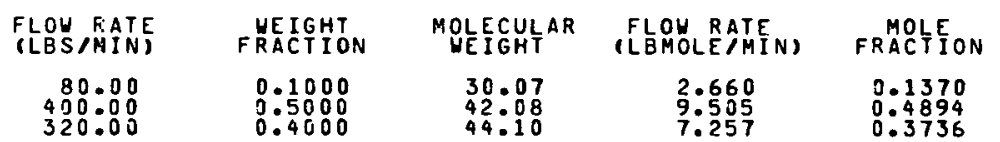




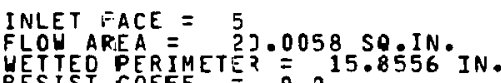
RESIST COEFF. $=0.00035$ INNER VALL RAOTHS $=205535$ IN.

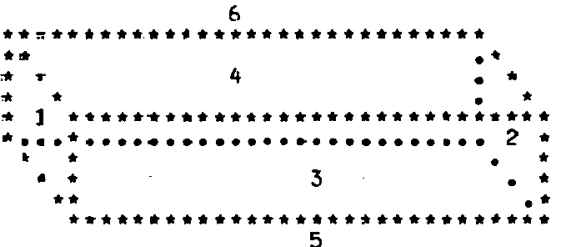

CUTLET FACE =

FLCY AFA A $=20.0059$ SO, IN.

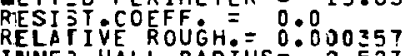

INNE? YALL RADIUS $=20$ 'E235 IN.

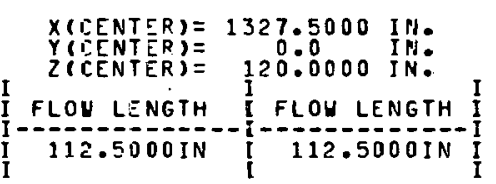

CONTENTS OF THE PRIMAFY STREAM: ( 3 COMPONENTSI $N$ INDEX FORMLLA USER CHEMICAL INAME $\begin{array}{llll}1 & 3 & \text { C2HG } & \text { ETHANE } \\ 2 & 4 & C 3 H 6 & \text { PROPENE COROPYLENE } \\ 3 & 5 & \text { C } 3 H B & \text { PROPANE }\end{array}$

TOTAL MASS FLOU RATE $=8000$ OLBS/MIN

TEMPERATURE OF THE PR TMARY STREAM = 24.9 OEG F

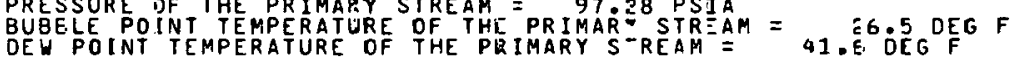
STATE OR CONOIIION OF THE PRIMARY STREAM : SUBCODELE LIQUIJ HEAT CONTENT OF THE LIJUIJ $=-1: 9548.26$ BTUMHIN $=-149.0^{44}$ BTUALB

LIOUID DENSITY $=32.73$ LBM/CU.FT'

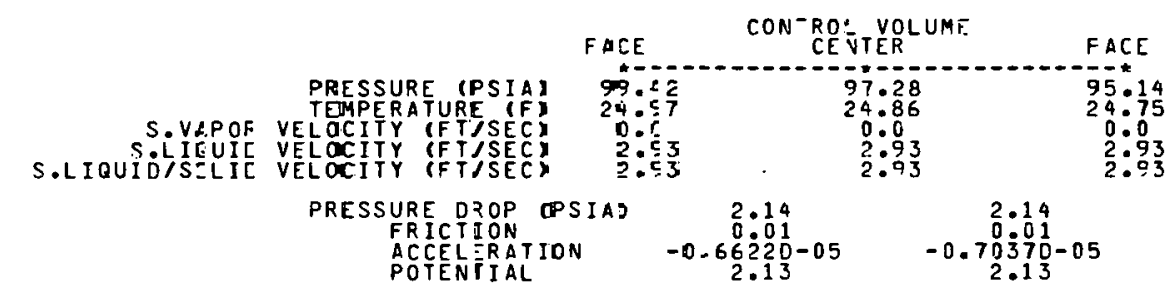

\begin{tabular}{|c|c|c|c|}
\hline FLO & $\begin{array}{l}\text { WEIGHT } \\
\text { FRATIION }\end{array}$ & $\begin{array}{l}\text { MELECWLAR } \\
\text { WETGTO }\end{array}$ & $\begin{array}{l}\text { FLOU RATE } \\
\text { (LBMOLEMMIM) }\end{array}$ \\
\hline $\begin{array}{l}800: 00 \\
400 \\
320 \\
300 \\
0.00\end{array}$ & $\begin{array}{l}0.1000 \\
0: 55000 \\
0.000 \\
0.000\end{array}$ & $\begin{array}{l}30: 07 \\
32: 08 \\
44: 10\end{array}$ & $\begin{array}{l}2: 660 \\
9: 505 \\
7: 25\end{array}$ \\
\hline
\end{tabular}




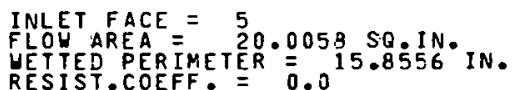
REAT INNER YALL RADIUS $=2.535$ IN.

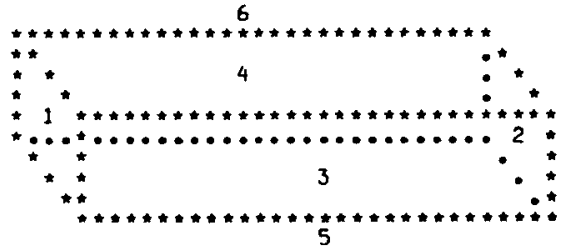

EXPERIMENTAL DATA:
INJECTED FLLU:
ADIABATIC:

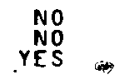

CONTENTS OF THE PRIMARY STREAM: 13 COMPONENTS

N INDEX FORMULA USER CHEMICAL NAME

$\begin{array}{llll}1 & 3 & C 2 H 6 & \text { ETHANE } \\ 2 & 3 & \text { C2MH6 } & \text { PROPE } \\ 3 & 5 & \text { P } 3 H 8 & \text { PROPANE (PROPYLENE) }\end{array}$

TOTAL MASS FLOU RATE $=8000$ O LBSIMEN

TOTAL

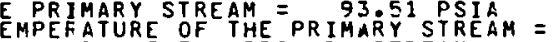

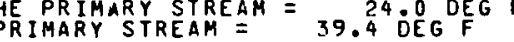

THE PRIMARY STREAM IS THO-PHASE AND HAS THE FOLLOHING VAPOR/LIQUID SPLIT:

COMPONENT

ETHANE
PROPENE (PROPYLENE)
PROPANE

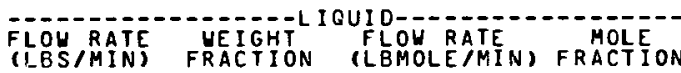

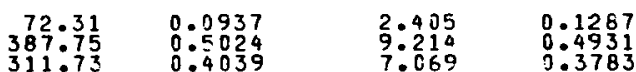

TOTAL LIOUID MASS FLOW RATE $=771.83$ LOSSMIMA

WEIGHT FRACTION OF THE PRIMARY STREAM THAT IS VAPOR $=0.0353$

MEAT CONTENT OF THE LIOUID $=-119537.73$ BTUMMIN $=-154.88$ BTU/LB

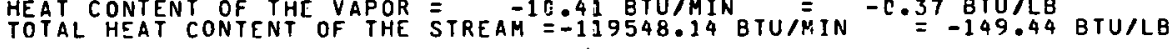

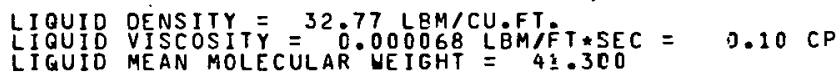

VAPOR DENSITY $=0.7746$ LBM

VAPOR MEAN MOLECULAR YEIGHT $=38.365$

VAPOR/LIQUID INTERFACIAL SURFACE TENSION $=0.576980-03$ LBF/FT $=8.420$ DYNE/CM

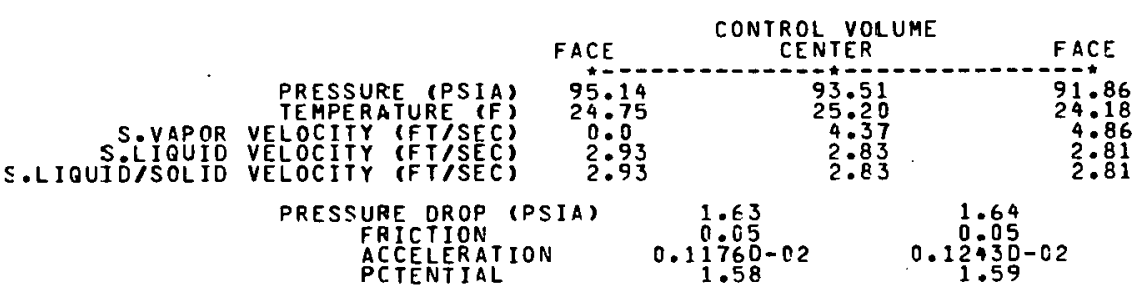

OUTLETFACE $=26.0058$ SQ.IN.

RESIST PERIMETER $=0.0005$

RELATIVE ROUCH. 0.000357
INNER YALLRADIUS 02.5235 IN
ANGLE (REL.TOHOR.)= 90.00 DEG

$X(C E N T E P)=132705000$ IN:
Y (CENTER)
Z(CENTER) 34500000 IN
IN

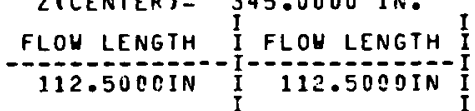

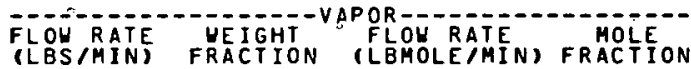

$\begin{array}{rlll}7.69 & 0.2725 & 0.256 & 0.3477 \\ 12: 25 & 0: 4344 & 0.281 & 0.3960 \\ 8.27 & 0.2931 & 0.187 & 0.2550\end{array}$ 


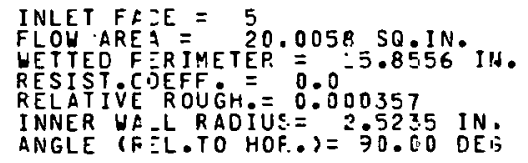

EXPERIMENTAL DATA:
INJECTEE FLOW:
ADIABTIS: YIJ

CONTENTS CF THE PRIMARY STREAM: I 3 COMPONENTS,

$N$ JNOEX FORMLLA USER CHEMICAL DAME

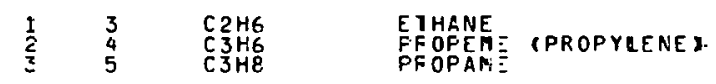

TOTAL MASE FLOW RATE $=$ EOOO OOLES $11 \mathrm{~N}$

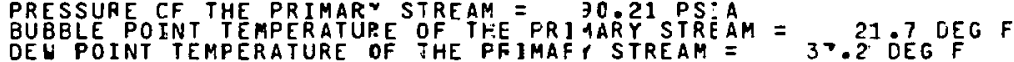

THE PRIMAFY STREAM IS IWO-PHASE ANG HAS THE FOLLOU:NG VAPOR/LIJUIO SPLIT:
COMPONENT

\section{ETLANE
PROPENE IPROPYLENE:
PROPANE}

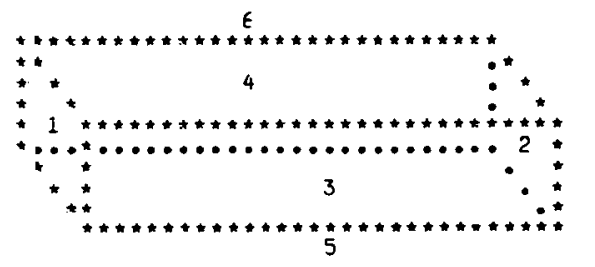

I FLOU LENGTH I FLOW LENGTH I
$X(C E N T E R)=1327.5000$ IN.
$Y$ (CENTER)
RESTST COEFF. = 0.00035

IN NER YALL RADIUS $=295235$ IN.
AN $B L E$ (REL.TO HOR, $)=90.00$ OEE

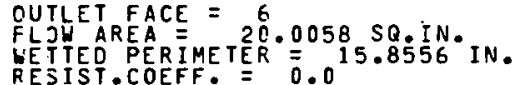

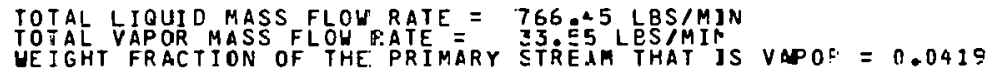

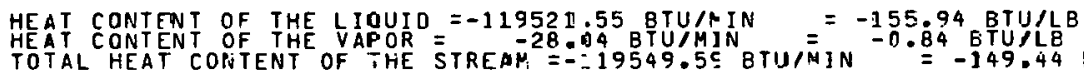

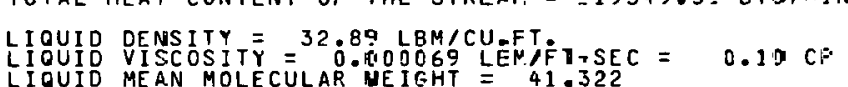

VAPOR DENSITY $=0.7482$ LBM/CU.FT.

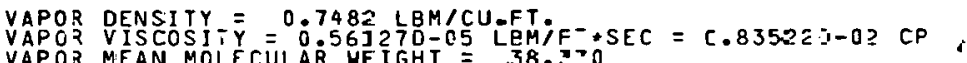

VAPOR MEAN MOLECULAR WEIGHT $=38.370$
VAPOR COMPRESSIEILITY FACTOR $=0.830$

VAP0.2/LIQUIC INTERFACIAL SURFACE TENSION $=6.58738[-03$ LBF/FT $=8.571$ DYNE/CM

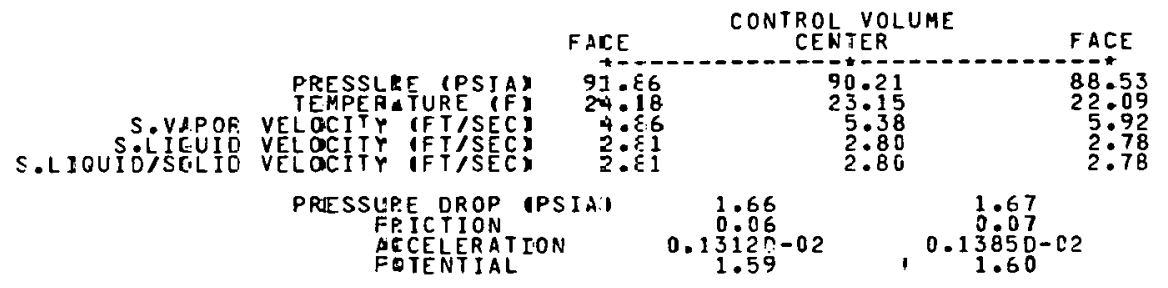




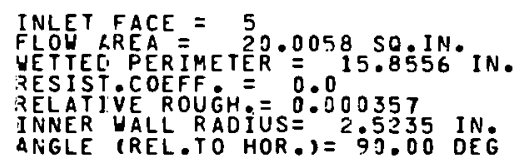

EXPERIMENTAL DATA: NO
NNJECEDOFLON:
ADIAGATIC: YOS

CONTENTS OF THE PRIMARY STREAM: ( 3 COMPONENTS)

N INDEX. FORMULA USER.CHEMICAL NAME

$\begin{array}{llll}1 & 3 & \text { C2HG } & \text { ETHANE } \\ 2 & 4 & C 3 H G & \text { PROPENE (PROPYLENE) } \\ 3 & 5 & \text { C } 3 H 8 & \text { PROPANE }\end{array}$

TOTAL MASS FLOW RATE = 800 OOLBSIMEN

21.0 DEG F

BUBGLE POINT TEMPEFATURE OREAM $=86.85$ PSIA

DF THE PRIMARY STREAM $=35.0^{19}$ DEG ${ }^{3}$ DEG F

THE PRIMARY SITREA IS TWO-PHASE AND TAS THE FOLLOHING VAPOR/LIQUIO SPLIT:

COMPONENT

ETHANE
PROPENE (PROPYEENE)
PROPANE

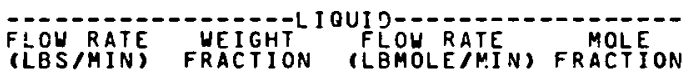

$\begin{array}{llll}69.41 & 0.0912 & 2.308 & 0.1254 \\ 383.00 & 0.5033 & 9.101 & 0.4945 \\ 308.54 & 0.4055 & 6.997 & 0.3802\end{array}$ $\vdots *$

$+$

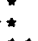

Z(CENTER) $=7900000$ IN.

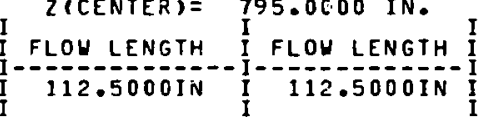

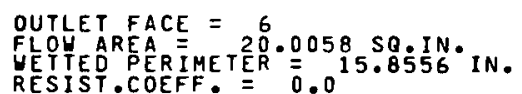

RELATIVE ROUGH $=0.00035$

INNER YALL RADIUS $=2.5235$ IN

\begin{tabular}{|c|c|c|c|c|}
\hline $\begin{array}{l}\text { FLON RATE } \\
\text { (LBS MININ) }\end{array}$ & $\begin{array}{l}\text { YEIGHT } \\
\text { FRACTION }\end{array}$ & $\begin{array}{l}\text { MOLECULAR } \\
\text { WEIGHT }\end{array}$ & $\begin{array}{l}\text { FLOU RATE } \\
\text { (LLBMOLEIMIN) }\end{array}$ & $\begin{array}{l}\text { MOLE } \\
\text { FRACTION }\end{array}$ \\
\hline $\begin{array}{r}80.00 \\
450: 00 \\
320000\end{array}$ & $\begin{array}{l}0.1000 \\
0.55000 \\
0.4000\end{array}$ & $\begin{array}{l}30.07 \\
42: 08 \\
44: 10\end{array}$ & $\begin{array}{l}2.660 \\
9: 505 \\
7.257\end{array}$ & $\begin{array}{l}0.1370 \\
0: 4894 \\
0.3736\end{array}$ \\
\hline
\end{tabular}

TOTAL LIQUID MASS FLOH RATE = 760.94 LBS/MIN

TOTAL VAPOR MASS FLOW RATE

HEAT CONTENT OF THE LIOUID $=-119499.50$ BTU/MIN $=-157.04$ BTU/LB

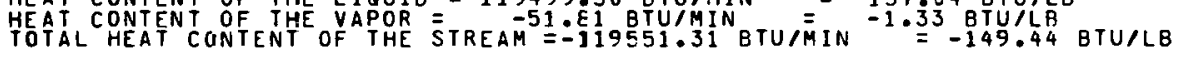

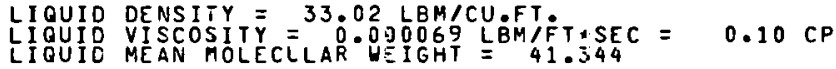

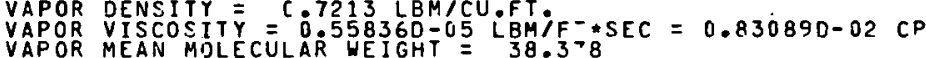

VAPOR MEAN MOLECULAR WEIGHT $=38.378$

VAPOR/LIOUIO INTEPFACIAL SURFACE TENSION $=0.598280-03$ LBF/FT $=8.730$ DYNE/CM

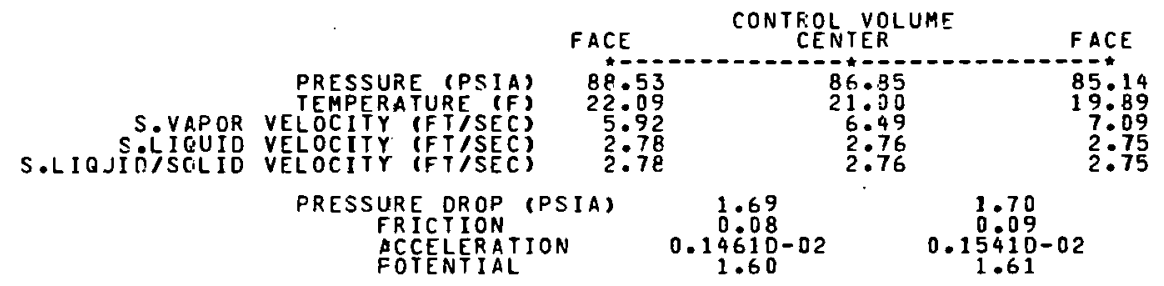

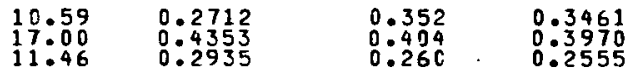

ACCELERATION
FOTENTIAL

$0.15410-02$ 


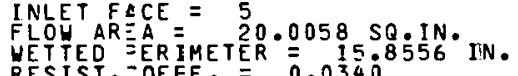
RESIST

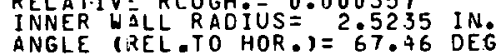

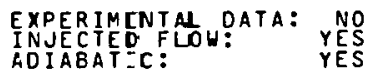

CONTENTS OF THE PRIMAFY STREAM: ( 3 CCMPONENTS)

N INDEX FORMLLA

$\begin{array}{llll}1 & 3 & \text { C2HG } & \text { ETHANE } \\ 2 & 4 & \text { C3HG } & \text { PROPENE (PROPYQENE) } \\ 3 & 5 & \text { C3HE } & \text { PROPANE }\end{array}$

TOTAL MASS FLOW RATE

PRESSURE OF THE PR IMARY S-REAM = 85.039 PS 1 A

BUBBLE POINT TEMPERATUFE CF THE PRIMARY STREAM $=33.7^{3}$ DE DEC. F

THE PRIMARY STREAM IS THO-PHASE AND HAS THE FOLLJWING VAPORILIQUID SPLIT:

COMPONENT

CTHANE
PROPENE IFROPYLENE
PROPANE

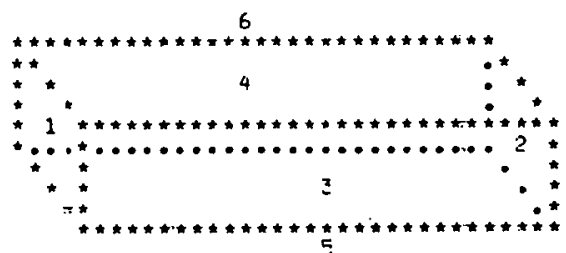

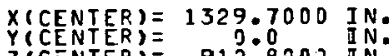

I FLOW LENGTH I FLOW LENGTH I

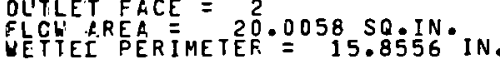

RESIST.CCEFF $=0.0340^{8}$

INNER HALL RADIUS $=2.5235$ IN

\begin{tabular}{|c|c|c|c|}
\hline FLOU & $\begin{array}{l}\text { WEIGHT } \\
\text { TEACTION }\end{array}$ & 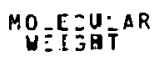 & $\begin{array}{l}\text { FLOH RATE } \\
\text { (LEMOLEMIMN) }\end{array}$ \\
\hline $\begin{array}{l}80: 30 \\
400 \\
320: 30 \\
320\end{array}$ & $\begin{array}{l}0: 1000 \\
0: 5500 \\
0 \\
0\end{array}$ & 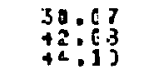 & $\begin{array}{l}2: 660 \\
9: 505 \\
7: 257\end{array}$ \\
\hline
\end{tabular}

TOTAL LIOUID MASS FLOH RATE $=757.92$ LBS/MIN

WETAL VAPOR MASS FLOU RATE

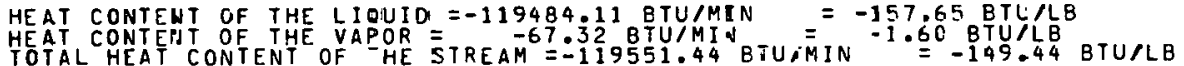

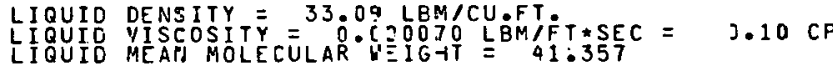

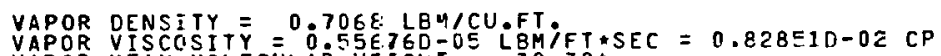

VAPOR VISCCOSITY
VAPOR MEAN
VAPOR COMPELEC

VAPOR/LIQUID INTERFACIAL S JRFACE TENSION $=0.6043 .30-03 \mathrm{LBF/FT}=$

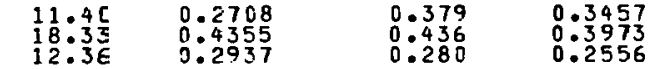


CONDITION (STATE) OF THE INNECTED FEED STREAM
CONTENTS OF THE FEEO STREAM! C 2 COMPONENTSI

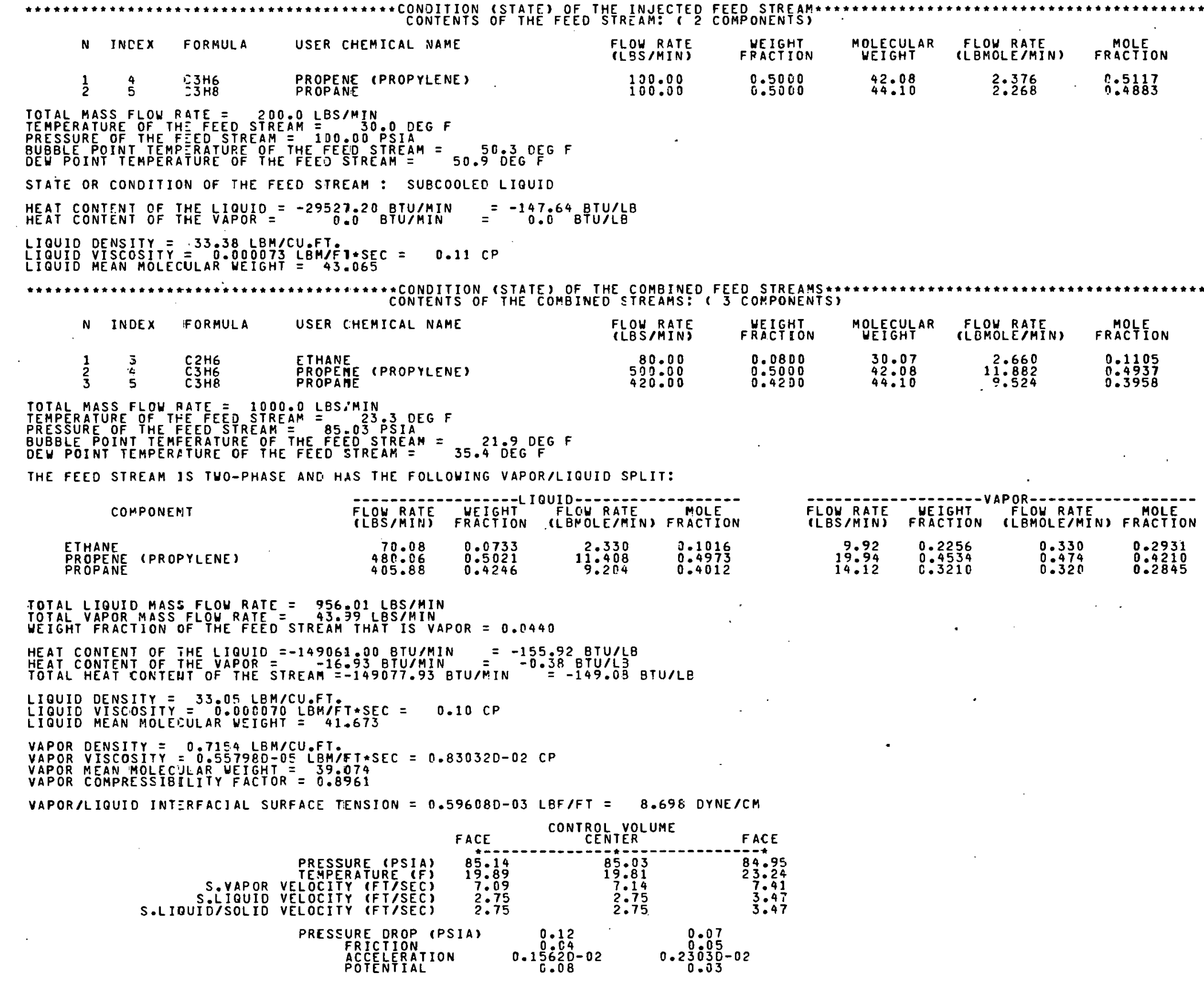


FFFAP-VEFSION 1.0

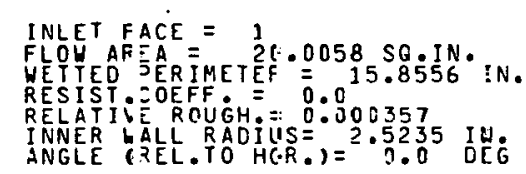

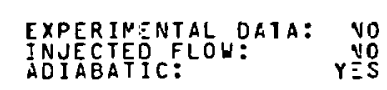

CONTENTS OF THE PRIMARY STREAR: 13 COMPOAENTE)

$N$ INDEX FORMULA LSER ZHEMICAL NAME

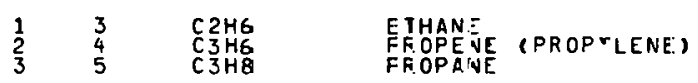

ZONTROL VJLUME (NODE) NO. 13

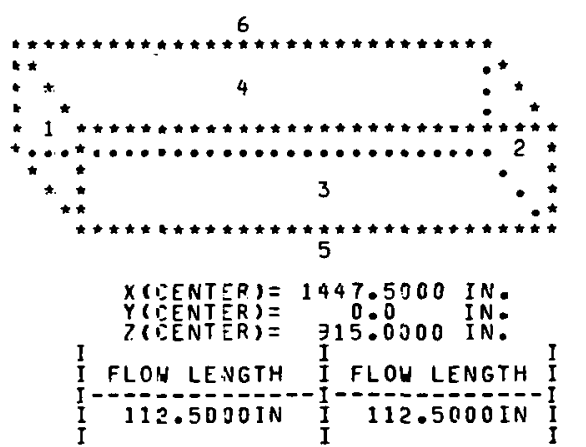

OJTLET FACE =

FIOH AREA

R $=L A$ IVE ROUGH $=0.00035$

I NAEF WALL RADIUS $=2.5235$ IN.

\section{TOTAL MASS FLOW RATE T 1000 TLLRSIMIN 23 TECE F}

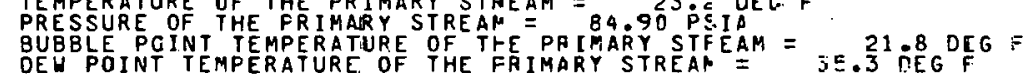

THE PRIMARY STREAM IS TWO-PLIASE ANO HAS THE FO!LOHING VAPOR/LIQUID SPLIT:

\begin{tabular}{|c|c|c|c|c|}
\hline $\begin{array}{l}\text { FLOH ZATE } \\
\text { (LBS/MIN) }\end{array}$ & FEEISTH & MDLECULAR & $\begin{array}{l}\text { FLOW RATE } \\
\text { (LBMOLEIMIN) }\end{array}$ & $\begin{array}{l}\text { MOLE } \\
\text { FRACIION }\end{array}$ \\
\hline $\begin{array}{r}80.00 \\
500: 00 \\
420.00\end{array}$ & $\begin{array}{l}0.0800 \\
0: 5000 \\
0.5200\end{array}$ & $\begin{array}{l}3.3 .07 \\
42: 08 \\
44: 10\end{array}$ & $\begin{array}{r}2.650 \\
11: 882 \\
9: 524\end{array}$ & $\begin{array}{l}0.1105 \\
0: 4937 \\
0: 3958\end{array}$ \\
\hline
\end{tabular}

COMPONENT

ETHANE
PROPENE (PFOPYLENE)
PROPANE

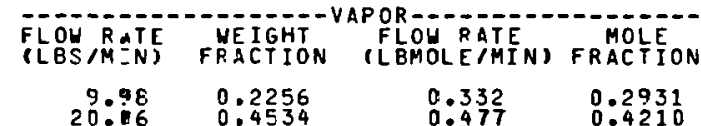

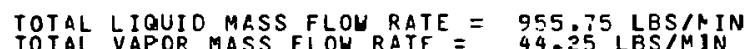

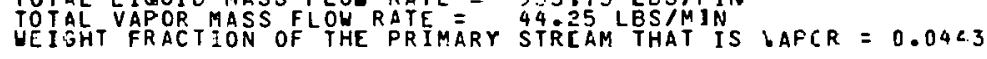

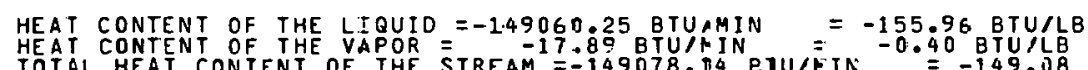

Ов вти/Lв

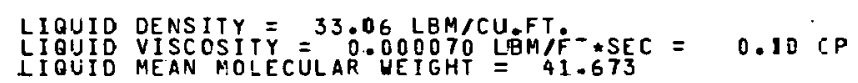

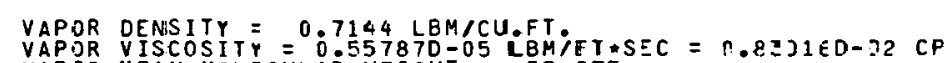

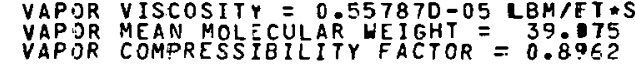

VAPORALIQUIO INTERFACJAL SURFACE TENSION $=0.555560-33$ LBFIFT $=8.704$ DYNE/CM

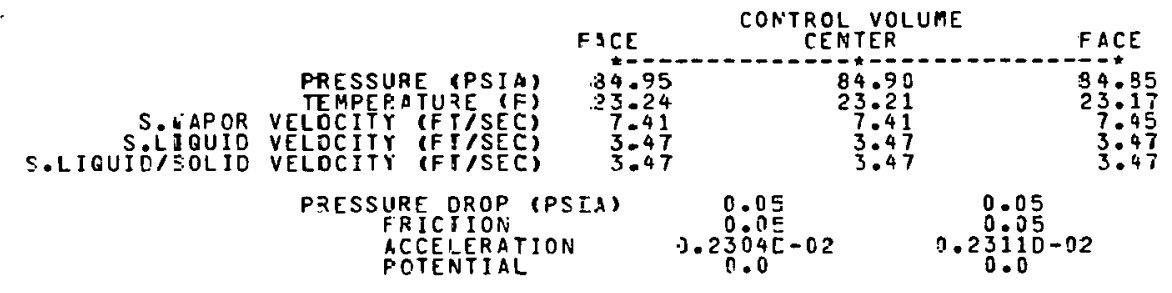




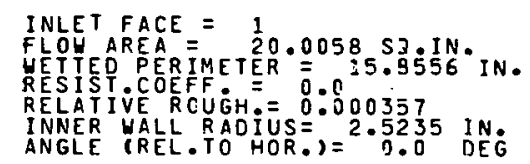

EXPERIMENTAL DATA: NO
INJECTEOCLOH:
ADIABATIC:

CONTENTS OF THE PRIMARY STREAM: ( 3 COMPONENTS)

INDE FORMULA

$\begin{array}{llll}1 & 3 & \text { C2HE } & \text { ETHANE } \\ 2 & 4 & C 3 H 6 & \text { PROPENE } \\ 3 & 5 & C 3 H E & \text { PROPANE }\end{array}$

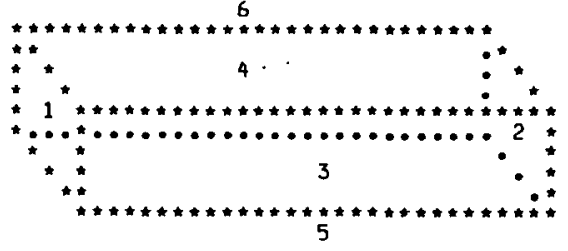

$X(C E N T \equiv R)=1672.5000$ IN.

Z(CENTER) $=915: 0000$ IN: I FLOH LENGTH I FLOU LENGTH I
OUTLET FACE $=2$
FLOUE AREA
UETTED PER IMETER 0058 SO.IN. $=15.8556$ IN.

RESIST COEFF. $=0.000037$

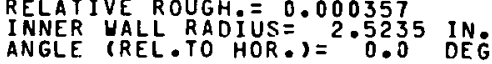

TEMPERATURE OLE RATE THE 1000 TO LBS /MIN 23 T 11 DEG

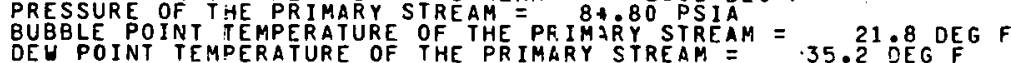

THE PRIMARY STREAM IS TWO-PHASE ANO HAS THE FOLLOHING VAPOR/LIQUIO SPLIT:

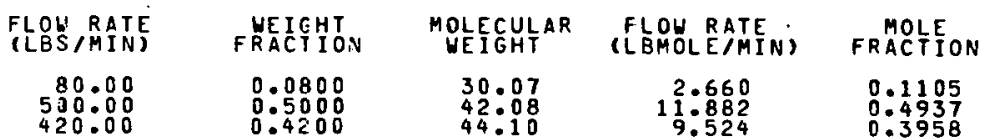
COMPONENT

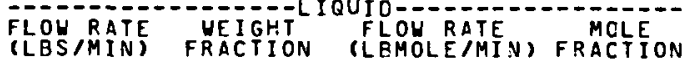
ETHANE
PROPENE (PROPYLENE)

$\begin{array}{llll}69.97 & 0.0732 & 2.327 & 0.1015 \\ 479.84 & 0.5022 & 11.403 & 0.4973 \\ 405.73 & 0.4246 & 9.201 & 0.4013\end{array}$

TOTAL LIOUID MASS FLOW RATE $=955.54$ LBS/MIN

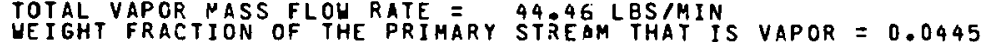

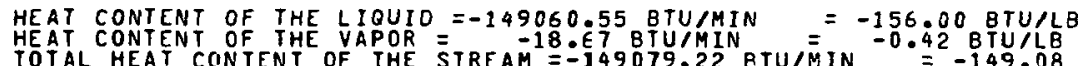

LOUID DENSITY $=33.06$ LBM/CU.FT'P
LIOUID VISCOSITY
LIOUID MEAN

VAPOR OENSITY $=0.7136$ LBM/CU FT

VAPOR VISCOSTTY $=07557780-55$ LEM 5 T

VAPORルLIQUID INTERFACIAL SURFACE TENSION $=0.596830-03 \mathrm{LBF} / F T=8.709$ DYNE/CM

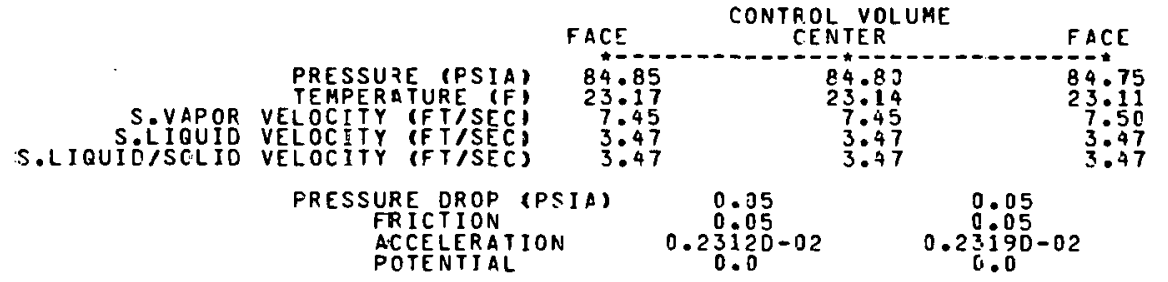

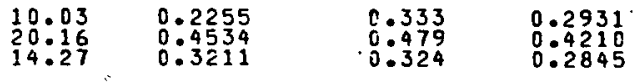



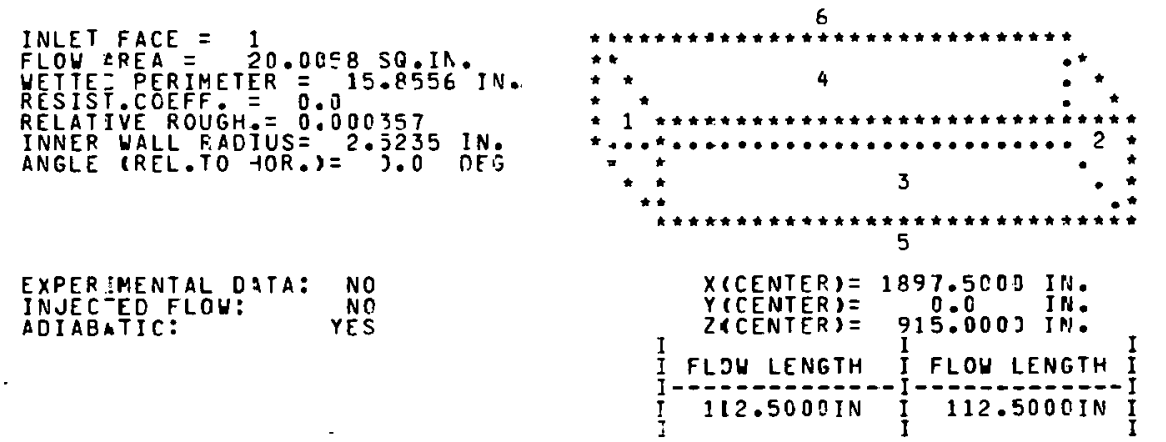

CONTENTS OF THE PRIMARY STREaM: ( 3 COMPONEN-S,

$N$ INDEX FOFMULA USER CHEMICAL NARE

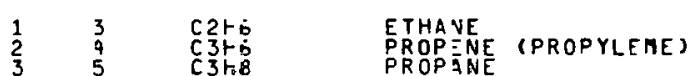
TOTAL MASS FLCH RATE = 1000 OR LRS IMIN TEMPERATURE OF THE PPIMARY SIAEAM $=84.723$ P 1 OEG BUBBLE FOINT TEMPERAIURE OF THE PRIMARY STREA 35.11 DEGFG F

THE PRIMARY STREAM IS THO-PHASE APID HAS THE FCLLOWIVE VAPCR/LIOUID SPLIT:

COMPONENT

\section{ETHANE
PROPENE (FROPYLEVE)
PROPANE (FOP}

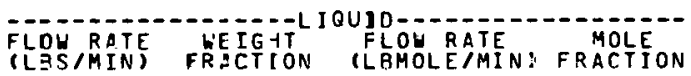

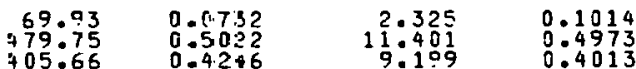

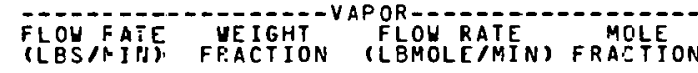

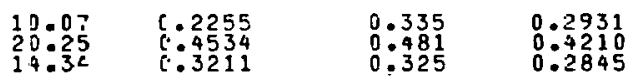

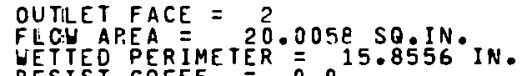

RELATITEROUGH. $=0: 000357$

INANR WALL RADIUS $=2.5235$ IN.

TOTAL LIOUIEMASS FLYWRATE $=955.33$ L8S/MIV

WEIGHT FPACTION OF THE PRIMARN STFEAM THAT IS VAPOP $=0.0447$

HEAT CONIENT OF THE LIOUID $=-1490 E 0.8+$ BTU $/ M I N=-156.013$ BTU/LB

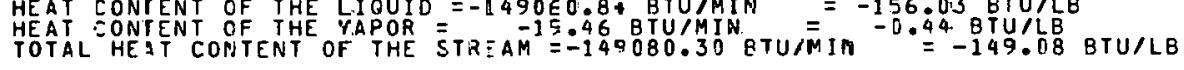

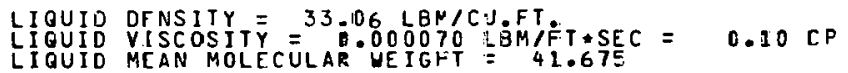

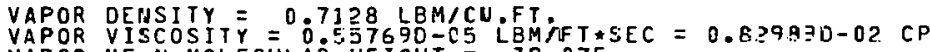

VAPOR MEAN MOL ECULAR WEIGHT $=39.075$

VAPOR/LIOUID INTERFACIAL SURFACE TEVSION $=0.597170-03$ LBFIFT $=8.714$ DYNEICM

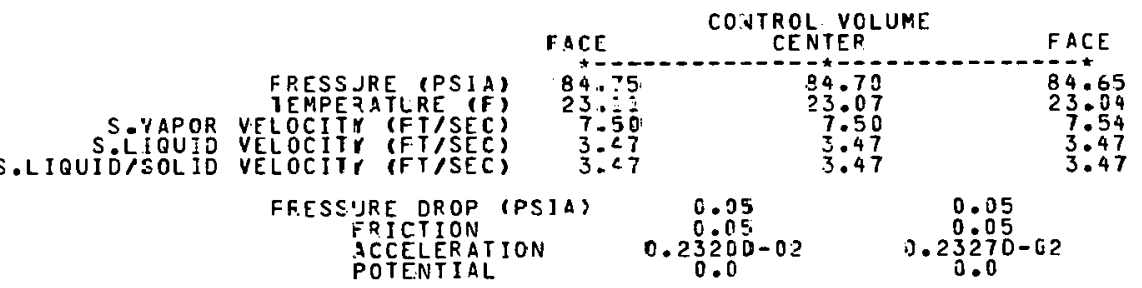




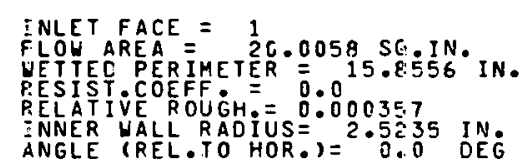

*<smiles>C1[C@H]2C[C@H]12</smiles>

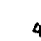

4

$*$

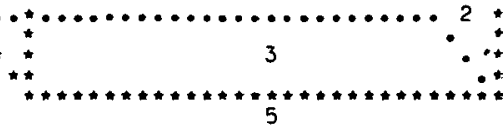

$X(C E N T E R)=2122.5000 \mathrm{IN}$

EXPER IMENTAL DATA: NO
INJECIED FLOH: NO
IDIABETIC:

CONTENTS OF THE PRIMARY STREAM: ( 3 IOMPONENTS,

N INOEX FORMULA USER CHEAICAL NAME

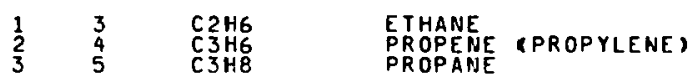

TOTAL MASS FLOW RATE $=1$ COOOJ LBSTMIN

ESSUE OF THE

BUBBLE POINT TEMPERATURE OF THE PRIMARY STSIAM

$35.1^{21} D_{E G}{ }^{D E G ~ F}$

THE PRIMARY STREAM IS TWO-PHASE AND HAS THE FOLLOWING VAPOR/LIQUID SPLIT:

COMPONENT

ETHANE (PROPYLENE)

PROPENE
FOU RATE FHEIGHT IQUIDOU FLOATE

$\begin{array}{rrrr}69.88 & 0.0732 & 2.324 & 0.1214 \\ 479.65 & 0.5022 & 11.398 & 0.4073 \\ 465.59 & 0.4246 & 9.198 & 0.4013\end{array}$

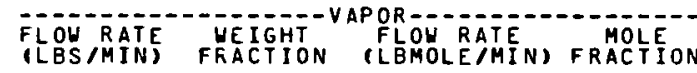

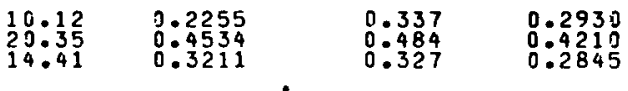

OUTLET FACE $=20^{2} .0058 \mathrm{SQ}$ IN. IN.

RESIST COEFF = $=0.00035$

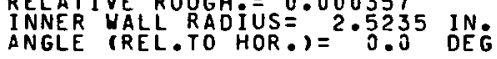

TOTAL LIGUID MASS FLOW RATE $=955.12$ LES MIN

UEIGHT FRACTICN OF THE PRIMARY STREAM THAT IS VAPOR $=3.0449$

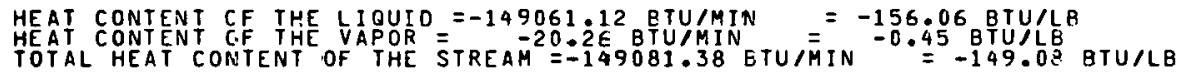

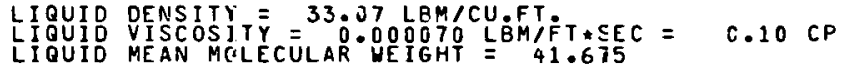

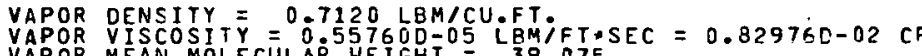

VAPOR MEAN MOLECULAR WEIGHT $=39.875$

VAPOR/LIQUID INTERFACIAL SURFACE TENSION $=0.597500-03 \mathrm{LBF/FT}=8.719$ DYNE/CM

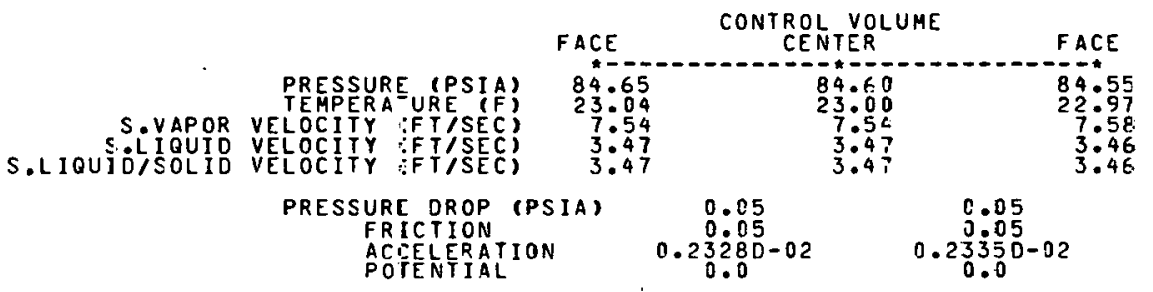




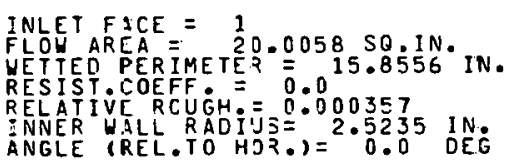

EXPERIMENTAL DATA: NO
INJECTECFLOH:
ACIABATEC:

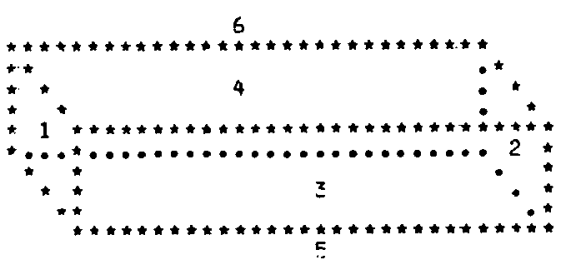

$X(C E N I E R)=2347.5000$ IN.

Y(CENTER)= 91500000 IN:

I FLON LENGTH I FLOU LEVGTH I

CONIENTS JF THE PRIMAPY STREAM: ( 3 COMPONENTS:

N INDEX FORMLLA U.JeR CHEMICAL VAME

$\begin{array}{llll}1 & 3 & \text { C2HG } & \text { E } 2 H A N E \\ 2 & 4 & C 3 H 6 & \text { PROPE } \\ 3 & 5 & C 3 H 8 & \text { PROPANE }\end{array}$

FLOY RATE HEIGHT

MOECJLAR FLOU RATE

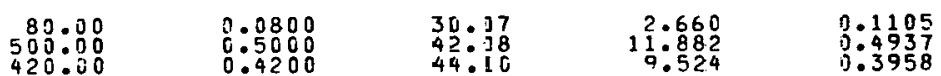

TOTAL MASS FLOH RATE 1000 TOOLBSIMIV 22.0 DEGF

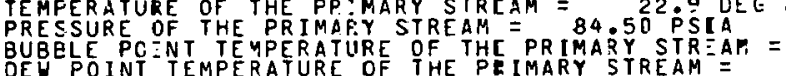

THE PFIMAFY STREAM IS TUO-PHASC AND HAS THE FOLLOUING VAPOR/LIQUID SPLIT:

COMPONEN T

ETHANE
PROPEDE (PROPYLENE)
PROPAHE

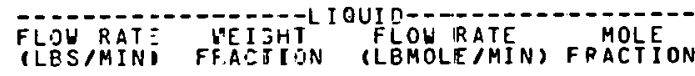

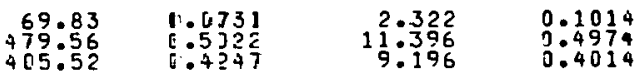

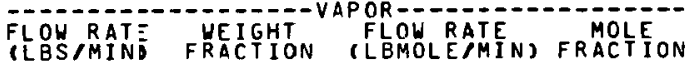

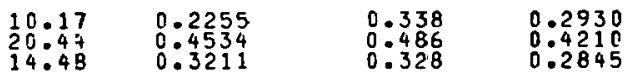

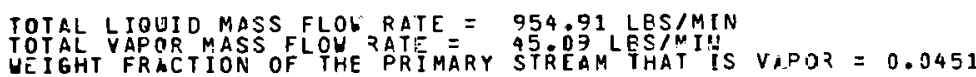

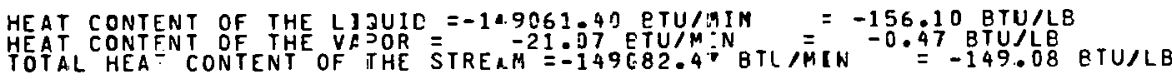

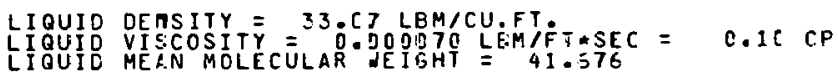

VAPOR DENSITY $=0.71112$ LBM/CUEFTH

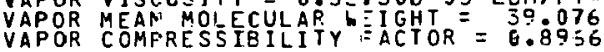

VAPOR/LIQUID INTERFACIAL SURFACE TEVSICN $=\$ .593840-03$ LEF/FT $=8.724$ DYNE/CM

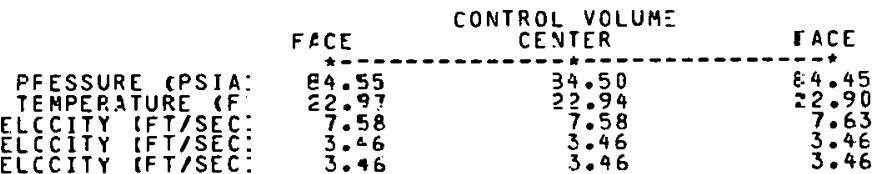

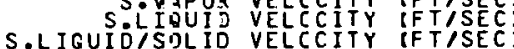

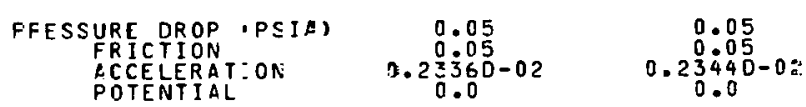

FLOLAREACE $=20.0158$ SO.IN. IN.

RESIST COLFF. $=$

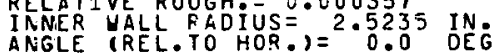




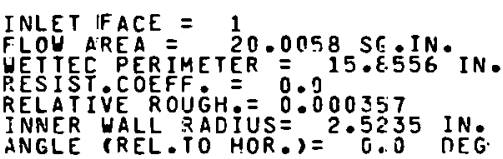

EXPER :MENTAL DATA: NO
INUEC EDEFLW:
ADIABTIC:

CONTENTS OF THE PFIMARY STREAM: ( 3 COMPONENTS )

$\begin{array}{llll}1 & 3 & C 2-16 & \text { ETHANE } \\ 2 & 4 & C 316 & \text { PROPENE (PROPYLENE) } \\ 3 & 5 & C 338 & \text { PROPANE }\end{array}$

TOTAL MASS FLCU RATE $=1000$ OOLES MMIN

TEMPERATURE OF THE PRIMARY STREAM $=22$.9 DEG

BUBBLE POINT TEMPERATURE OF THE PRIMARY STREAM

THE PRIMARY STREAM IS TWO-PHASE AND HAS THE FOLLOUING VAPOR/LIGUID SPLIT:
COMPONENT

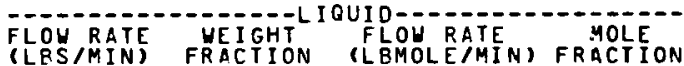

ETHANE (PROPYLENE)
PROPENE (PROPL $\begin{array}{rrrr}69.79 & 0.0731 & 2.321 & 0.1013 \\ 479.46 & 0.5502 & 11.394 & 0.4774 \\ 405.46 & 0.4247 & 9.195 & 0.4014\end{array}$

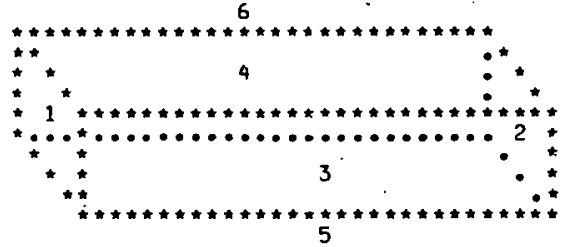

$X(C E N T E R)=2572.5000 \mathrm{IN}$

Z(CENTER) $=915: 0000$ IN: I FLOH LENGTH I FLOU LENGTH
RETIED PERIMETER $=15.8556 \mathrm{IN}$

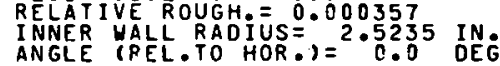

OUTLET FACE $=220058$ SQ.IN.

TOTAL LIOUID MASS FLOH RATE $=954.70$ LBS/MIN

TOTAL VAPOR MASS FLOH RATE Ä 45.30 LBSTMIN

HEAT CONIENT DF THC LIOUID $=-149061.077$ BTU/MIN $=-156.13$ BTU/LB

HOTAL HEAT CONTENT OF THE STREAM $=-179083.56$ BTU/MIN $=0.48$ BTU/LE $=149.08$ 3TU/LB

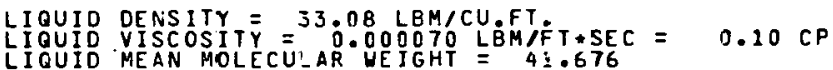

VAPOR DENSITY $=0.7103$ LBM

VAPOR MEAN MOLECULAR WE IGHT $=39.076$
VAPOR COMPRESSIBILITY $K$ TCTOR $=0.8967$

VAPOR/LIQUID INTERFACIAL SURFACE TENSION $=0.598190-03$ LBF/FT $=8.729$ OYNE/CM

CONTROL VOLUME

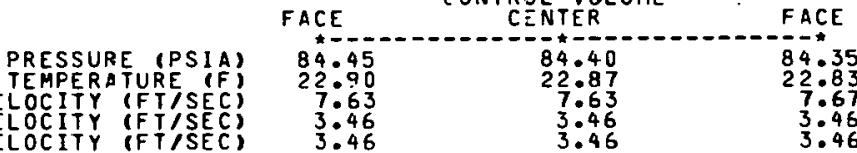

S. VAPOR VELOC VITY (FISSEC)

PRESSUF:E DROP (PSIA)

FEICCTION

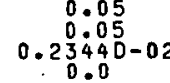

0.05
$0.235205-02$
0.00

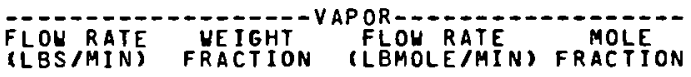

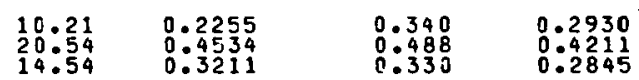




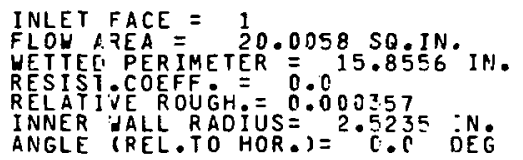

EXPERIMENTAL DATA: NO
INJECTED FLOH: NO
ADIABTIC:

CONTENTS OF THE PRIMAARY STREAM: I 3 COMPCNENTS

N INDEX FORIMULA USEA CHEMICAL NAYE

$\begin{array}{llll}1 & 3 & \text { C2H } & \text { ETHAUE } \\ 2 & 4 & C 3 H G & \text { PROPCNE } \\ 3 & 5 & \text { C } 3 H E & \text { PROPANE }\end{array}$

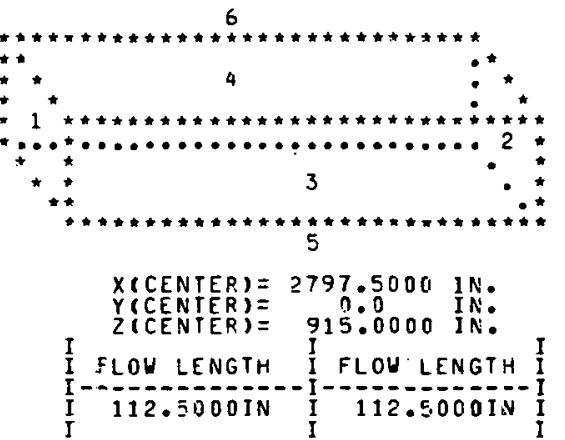

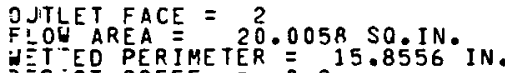

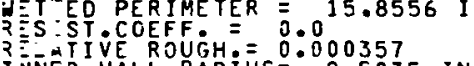

I NNER HALL RADIUS $=2.5535$ IN.
ANGL (REL.TOHOR.)
0.00

TOTAL MASS FLOW RATE = $10000^{0}$ LBSIMIN 22.8 DEG F PRESSURE OF THE PRIMARY STREAM $=84.292$ FS DEG

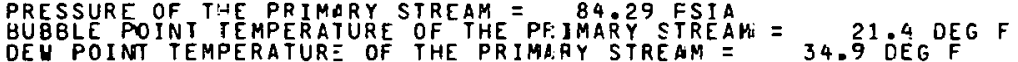

THE PRIMARY STREAM IS TWO-PHASE AMO HAS THE FGELCWIVG VAPOR/LIOUID SPLIT:

COMFONENT

ETHANE
PROPENE (PROPYLENE)
PROPANE

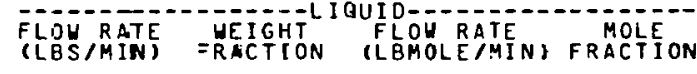

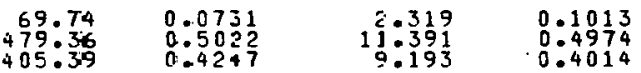

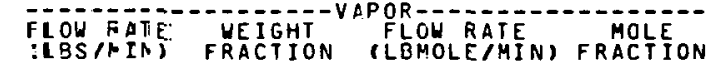

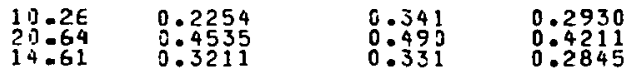

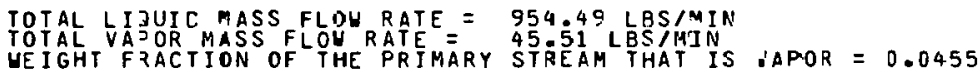

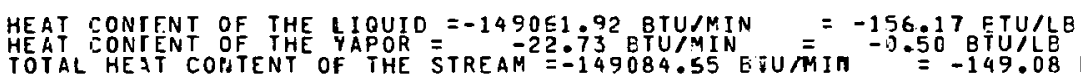

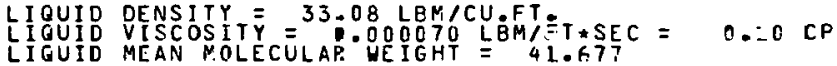

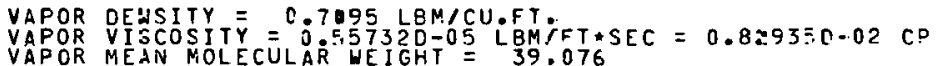

VAFOR COAPRESSIBILITY FACTOR $=0.3968$

VAPOR/LIOUID INTERFACIAL SURFACE TENSION $=0.598530-03 \mathrm{LBF} / F T=8.734$ OYNE/CM

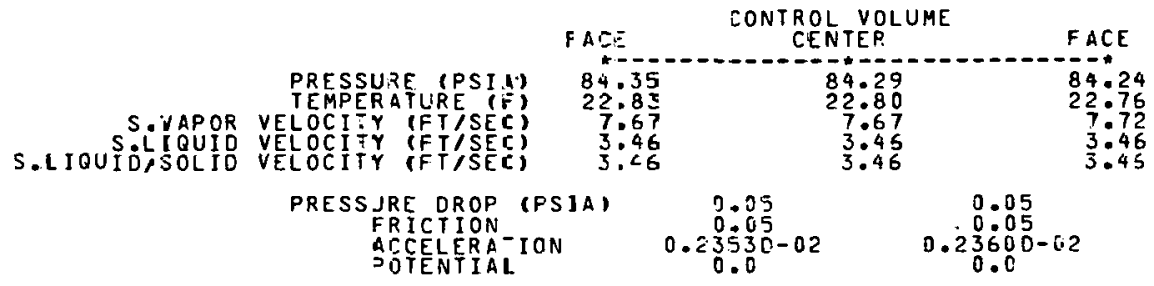




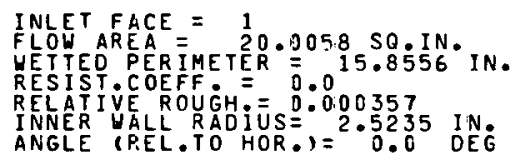

EXPERIMENTAL DATA: NO
INJECTEDTELW:
ADIABATIC:

CONTENTS OF THE PRIMARY STREAM: ( 3 COMPONENTS)

$N$ INDEX FORMULA USER CHEMICAL NAME

$\begin{array}{llll}1 & 3 & \text { C2H6 } & \text { PTHANE } \\ 2 & 4 & \text { C3HE } & \text { PRDPENE } \\ 3 & 5 & \text { C3HE } & \text { PRDPANE }\end{array}$

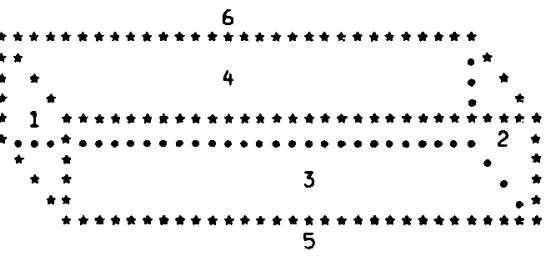

$X(C E N T E R)=3922.5000$ IN.
Y(CENTER $)=9000000$ IN:
Z(CENTER $=915.0000$ IN:

I FLOH LENGTH I FLOH LENGTH I I

OUTLET FACE $=22.0058$ SO.IN.

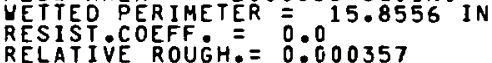

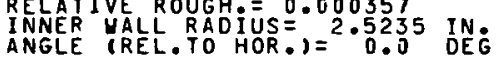

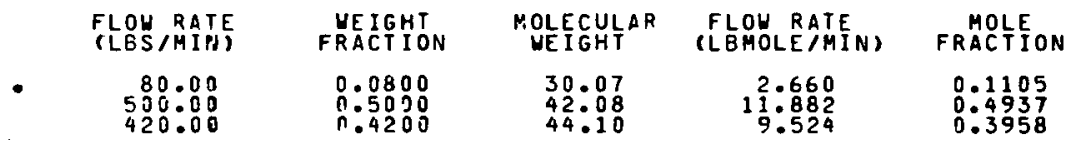

PRESSURE OF THE PR IMARY STREAM = 84 . 19 PSIA
BUBBLE POINTTEMPERATUR OF THE PRIMARY STREAM =
DEW POINT TEMPERATURE OF THE PRIMARY STREAME DEG F

THE PRIMARY STREAM IS TUO-PHASE AR:D HAS THE FOLLOUING VAPOR/LIQLIO SPLIT:

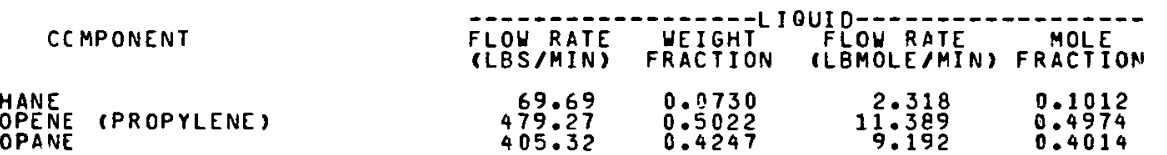

ETHANE
PROPENE (PROPYLENE)
PROPANE

$\begin{array}{llll}469.69 & 0.0730 & 2: 318 & 0.1012 \\ 405: 37 & 0: 5022 & 11309 & 0.4974 \\ 405 & 0.4247 & 9.192 & 0.4014\end{array}$

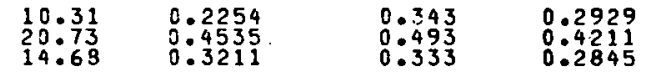

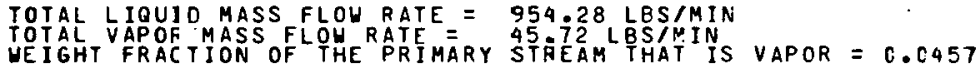

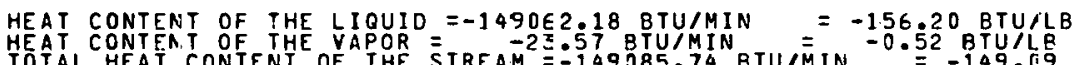

6. BTU/LA

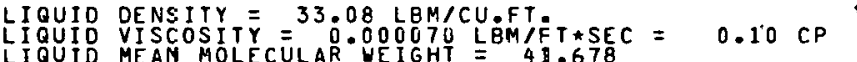

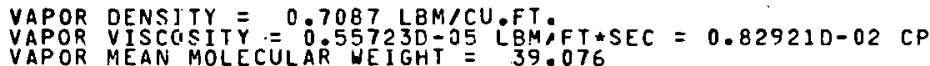

VAPOR MEAN MOLECULAR WEIGHT $=39.076$

VAPOR/LIGUID INTERFACIAL SURFACE IENSION $=0.598870-93$ LBF/FT $=9.739$ OYNE/CM

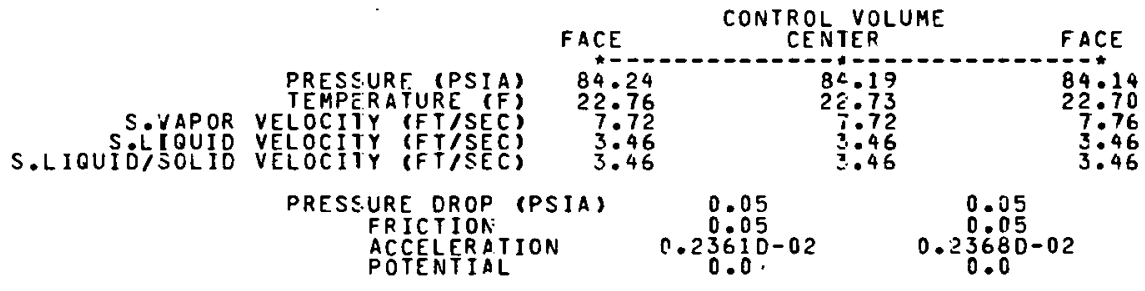




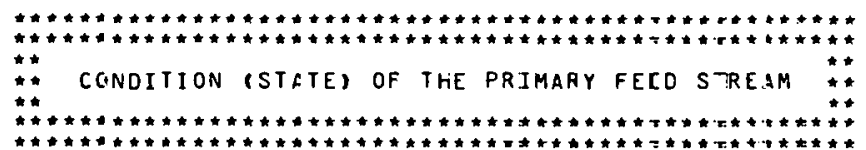

CONTERTS OF THE FEED STREAM: ( 3 COMPOUENTE)

$N$ INDEX FORMULA USER CHEMICAL WAME

$\begin{array}{llll}2 & 3 & \text { C2HE } & \text { ETHANE } \\ 2 & 4 & \text { C } 3 H E & \text { PRDPENE } \\ 3 & 5 & \text { C } 3 H B & \text { PRDPAOPYE }\end{array}$

TOTAL MASS FLOW RETE $=1000.0$ LESTMIN

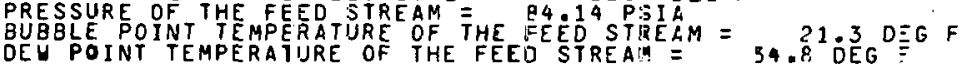

THE FEED STREAM IS TWO-PHASE ANO HAS THE FO_LCdING VAPOZ/LIQUIC SPLIT:

COMPONEN 1

E-HANE
PFOOPENE (PROPYLENE)
PFOPANE (POT

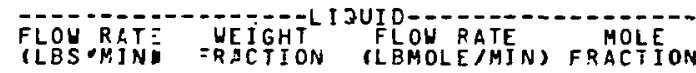
$\begin{array}{llll}69.67 & 0.9730 & 2.317 & 0.1912 \\ 473.22 & 0.5022 & 11: 386 & 0.4974 \\ 405.28 & 0.4248 & 9.191 & 0.4014\end{array}$

TOTAL LIOUID MASS FLON RATE $=954.1713$ STMEN

TOTAL VAPOR MASS FLOWRATE = 4 TEA FRACTION OF THE FEED STREAM THAT IS AAP JR $=0.0458$

HEAT CONTENT OF THE LIQUID $=-149061.88$ TTUM OIN $=-155.22$ BTU

LIOUID DENSITY $=33.09$ LLBM/CU.FTET

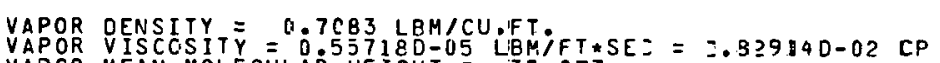

VAPOR MEAN MOLLCULAR UEIGHT $=3$ TE 30777
VAPOR COMPRESSIBILITYFACTOR $=0.8969$

VAPOR:LIQUIO INTEFFACIAL SURFACE TENSIOA $==.559550-03$ LBF/FT $=.8 .741$ DYNEACM

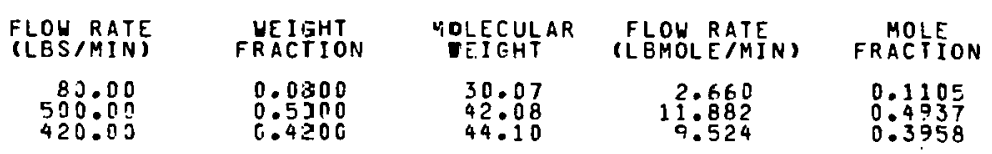


ORNL/TM-8160

\section{Internal Distribution}

$\begin{aligned} \text { 1. } & \text { R. A. Bradley } \\ 2 . & \text { P. K. Carlson } \\ 3 . & \text { D. W. Collins } \\ 4 . & \text { D. M. Eissenberg } \\ 5 . & \text { D. S. Griffith } \\ 6 . & \text { J. R. Horton } \\ 7-11 . & \text { A. A. Khan } \\ 12 . & \text { E. L. Long, Jr. } \\ 13-17 . & \text { L. J. Ott }\end{aligned}$

18. M. Siman Tov

19. E. C. Slade

20. C. B. Smith

21. H. E. Tramme11

22. ORNL Patent Office

23. Central Research Library

24. Document Reference Section

25-26. Laboratory Records Department

27. Laboratory Records (RC)

\section{Externa1 Distribution}

Wil sonville SRC Pilot P1ant, Catalytic, Inc., Wilsonville, AL 35186
28. P. Barnett
29. H. Blair
30. H. E. Lew is

Southern Company Services, Inc., P.0. Bóx 2625, Birmingham, AL 35202

31. E. L. Huf fman

H-Coal SRC Pilot P1ant, Ash1and Synthetic Fue1s, Inc., Box 391, Ash1and, KY 41101
32. N. Bond
33. W. R. Mil1er
34. D. Santore, DOE

Exxon Coal Liquefaction P1ant, Exxon USA, 5011 Baker Road, Baytown, TX 77520

35. R. Basile

36. F. F. McConne11, DOE

Exxon Research and Engineering Company, Box 101, Florham Park, N 07932

37. W. R. Epper1y

38. R. J. Platt

39. O. Sore11

PAMCO, Solvent Refined Coal Plant (Fort Lew is), Box 199, DuPont, WA 98327

40. C. Ackerman

41. D. R. Canfie1d 
Warren Petroleum Company, Box 1589, Tu1sa, OK 74102

42. S. O'Toole

International Coal Refining Company, Box 2752, Allentown, PA 18001

43. V. D' Imperio

44. T. W. F1aherty

45. T. Thew

DOE - Fossil Energy, Washington, DC 20545

46. J. P. Carr

47. T. Simpson

DOE-PETC, Box 10940, Pittsburgh, PA 15236

48. S. Let

DOE-METC, Box 880, Morgant own, WV 26505

49. D. Dubas

50. D. Freeburn

Oak Ridge Associated Universites, Oak Ridge, TN 37830

51. MERT Division

TVA, 1020 Chestnut Street Tower 2, Chattanooga, TN 37401

52. Michael D. High

EPRI, P. O. Box 10412, 3412 Hillview Ave., Palo Al to, CA 94303

\section{Librarian}

University of Kentucky, Institute of Mining \& Minerals Research, 213 Bradley Ha11, Lexingt on, KY 40506

54. Librarian

55. Office of Assistant Manager for Energy Research and Development, Department of Energy, ORO, Oak Ridge, TN 37830

56-82. Technical Information Center, DOE, Oak Ridge, TN 37830 